\title{
Recalling the Georgic: Land, Labor, and Literature in American Ecological Consciousness
}

\author{
Sam Horrocks \\ West Virginia University, sahorrocks@mix.wvu.edu
}

Follow this and additional works at: https://researchrepository.wvu.edu/etd

Part of the American Literature Commons

\section{Recommended Citation}

Horrocks, Sam, "Recalling the Georgic: Land, Labor, and Literature in American Ecological Consciousness" (2020). Graduate Theses, Dissertations, and Problem Reports. 7540.

https://researchrepository.wvu.edu/etd/7540

This Dissertation is protected by copyright and/or related rights. It has been brought to you by the The Research Repository @ WVU with permission from the rights-holder(s). You are free to use this Dissertation in any way that is permitted by the copyright and related rights legislation that applies to your use. For other uses you must obtain permission from the rights-holder(s) directly, unless additional rights are indicated by a Creative Commons license in the record and/ or on the work itself. This Dissertation has been accepted for inclusion in WVU Graduate Theses, Dissertations, and Problem Reports collection by an authorized administrator of The Research Repository @ WVU.

For more information, please contact researchrepository@mail.wvu.edu. 
Recalling the Georgic: Land, Labor, and Literature in American Ecological Consciousness

\author{
Sam Horrocks \\ Dissertation submitted \\ to the Eberly College of Arts and Sciences \\ at West Virginia University \\ in partial fulfillment of the requirements for the degree of \\ Doctor of Philosophy in \\ English \\ Timothy Sweet, Ph.D, Chair \\ Stephanie Foote, Ph.D \\ John Lamb, Ph.D \\ William Conlogue, Ph.D \\ Department of English
}

Morgantown, West Virginia

2020

Keywords: Georgic, Pastoral, Literature, Environment, Economics, Ecocriticism, Agriculture, Urbanization, Industrialization, Agrarianism

Copyright 2020 Sam Horrocks 


\begin{abstract}
Recalling the Georgic: Land, Labor, and Literature in American Ecological Consciousness
\end{abstract}

\title{
Sam Horrocks
}

This dissertation argues that environmentalism and the environmental humanities are limited by an overinvestment in the discursive mode of pastoral, which provides the ecological logic of industrial urbanization by viewing the environment from the perspective of a leisured and alienated spectator. The pastoral mode enables environmental injustice by separating the realms of ecology and economy through a conventional elision of issues of labor and economics, rendering environmentalism unable to effect change within the spheres most important to ameliorating the pollution crisis. The pastoral mode thus frustrates the overarching goal of ecocriticism and environmentalism: we seek an ontological reunion of nature and culture within an urbanized economic system that perpetuates their separation. To theorize economics from an ecological perspective, I suggest ecocriticism elevate the pastoral's undertheorized counterpart, the georgic mode, which conceives environment as a cultural space, from the perspective of an ethically engaged laborer. After making this theoretical argument in the introduction, chapters investigate the role of pastoral and georgic in the American economy and environmental imagination from the Revolution to today. Overall, this dissertation traces a gradual forgetting of the georgic mode within environmental discourse and labor concurrent with the expansion of urbanization, indicates the way this recession has enabled the global environmental crisis, and suggests how a popular recollection of georgic discourse could lead to a more sustainable and ethical mode of human life on earth. 
Table of Contents

1. The Pastoral Ascent in American Ecological-Economy 1

2. Burns and Georgic at the Industrial Turn 23

3. Crèvecoeur and the Roots of American Agrarianism 50

4. Thoreau's Transcendental Georgic 76

5. Sandburg and the Pastoral Logic of Urbanization 106

6. Recalling the Georgic 131

$\begin{array}{ll}\text { Bibliography } & 163\end{array}$ 


\section{The Pastoral Ascent in American Ecological-Economy}

I.

In the 21 st-century, climate change is already disrupting the oil-fueled global economic order. Sea level rise, increasingly violent and high-stakes fuel wars, chaotic migration crises, and disruptions to industrial agricultural production are likely to drastically reduce not only the human population, but that of countless other species; some scientists predict an extinction event massive enough to haunt the geologic record for millennia. Our ability to respond to these ecological changes will be hampered by biodiversity loss and ecological instability caused by pollution and habitat destruction. And, of course, the brunt of the disaster is sure to be borne by human populations disadvantaged by geography, ethnicity, and general lack of political and economic capital. But the crisis isn't environmental; the environment will be fine. It will bend, warp, twist and continue its constant activity of emergence. The crisis is human; the crisis is economic, and our economies are guided by our imaginations.

Cultural theorists attempting to think ecologically, often working under the disciplinary banner of "ecocriticism," have aided the broader environmentalist movement by recognizing that our difficulty enacting positive ecological change is due not to a failing of politics or will, but of ontology, of how we conceptualize the nature of our being as a culture. Ecocriticism's early and continuing aim is to develop new conceptions of the human relationship to our environment that can serve as a cultural rationale for, and spur to, broad social changes that reduce pollution and ecological exploitation, increase conservation, and remediate the effects of climate change. In this sense, ecocriticism is animated by the promise of a literary-theoretical "return to activism" and a "re-engagement with realism" that would extend outside of the academy to assist in the aversion of environmental catastrophe (Parini). Ecocriticism has made progress in that 
reconceptualization by recognizing that the ontological foundations of modern society rest in a flawed Enlightenment separation of culture and nature into two distinct categories of being, a dichotomy closely layered beside those of the mind and body, human and nonhuman. These dubious dichotomies enable and cause social and environmental destruction by permitting economic exploitation of nonhuman beings, from animals and plants to aquifers, mountaintops, and dehumanized ethnic and gender groups. The central ecocritical project is to develop an alternate philosophical paradigm that is ecological and "biocentric," a vision of "natureculture" that, with widespread acceptance, can reveal the cruelties and injustice of environmental exploitation and ignite accordant political-economic change (Haraway, Buell Environmental).

Over the last thirty years, ecocriticism has developed this idea into a sophisticated and influential theory of socio-ecology, inspired its application in fields across and beyond the humanities, and filtered it throughout society through the usual channels of teaching and writing.

Yet though these concepts have successfully penetrated, influenced and helped expand the broader environmentalist movement, we have not witnessed much progress within our global economic systems. Environmentally destructive production and consumption habits are more widespread and necessary for human survival than ever before, and paradigms of "growth" still dominate economic discussion among academics, policy makers, and laymen. Rather than moving beyond the flawed ideological assumptions of classical liberalism, the West has reentrenched them in neoliberal politics, spurring the increasing concentration of global capital in the hands of fewer corporate interests operating largely beyond the jurisdiction of governmental regulatory bodies. And as these transnational corporate actors expand industrial pollution to immense magnitudes and we begin to witness the devastating effects of climate change in the increasing frequency of extreme weather events, the environmental movement 
seems to be on the defense in the US and Europe, while political resistance to environmentalism has reinforced and entrenched its position. This is most evident in the apparent inability of the global political establishment to set, let alone achieve, the emission limits necessary to mitigate catastrophe for large portions of the world's human population. Technological progress has enabled the development of cleaner energy sources, yet we appear to lack the ability to use them. Rather than the postcarbon future of renewable energy and consumptive shifts imagined by environmental activists, we appear to be entering what Michael Klare terms an era of "Tough Oil," in which the world's political powers aggressively pursue the remaining reserves of fossil fuels to fuel increasingly desperate attempts to control the climate, despite greater environmental and social costs of extraction.

As a movement that seeks to shape our cultural attitudes and actions toward our habitat, ecocriticism — and environmentalism more broadly — must ask itself where we are going wrong and what more we can do. Why, despite the enthusiasm and interest they generate, are our theorizations unable to penetrate the economy in which we need them to take root? One reason we do not have much of an answer is that we have not yet bothered much with the question. As Wendell Berry has been arguing since the 1970s, environmentalism "has no economic program, and because it has no economic program it has the status of something exterior to daily life" ("Horse" 77). Ecocriticism has unfortunately reproduced this deficiency. Despite the fact that economic changes are ultimately what we most desire to effect, ecocriticism tends to elide discussion of what those changes might look like and how we might get there, in effect separating the realm of (human) economy, or the ways we daily subsist on the earth through labor, from our visions of (natural) ecology. 
If it wants to effect economic change, ecocriticism must theorize economy. Yet Lawrence Buell's 2011 article reviewing the disciplinary history and identifying "Some Emerging Trends" of ecocriticism does not contain the words "labor," "economy," or "agriculture." But these terms represent the processes by which human culture is most directly connected to its nonhuman environment, and must be as thoroughly interrogated as the more frequent ecocritical targets of "nature" (found on 19 pages of Buell’s essay), "animal" (4 pages), and "wilderness" (3 pages). Part of the problem is that the Enlightenment slowly dislodged the very term "economy" from its roots in the Greek "oikonomia," or "management of a household or a family," so that today "economy" calls to most American minds fuzzy and confusing networks of global financial shenanigans, measured by points on the Dow, GNP and unemployment rates ("economy, n."). Those trained in the environmental humanities may thus feel unqualified or insufficiently informed to discuss such matters, much less to offer economic prescriptions. Yet we must remember that our current conception of "economy" can be subject to the same methods of critique we in the humanities level at ideas of "race," "gender," and "nature." And it is indeed is in dire need of such problematizing, since common measures of economic health such as GNP possess weak, if any, positive correlation to actual human welfare (Daly 15). As Jennifer Hamilton argues in the brief entry for "Labour" in the Living Lexicon for the Environmental Humanities, the field "needs a ... kind of manual gearing, because for any kind of ethical, and, indeed, livable future on the planet, we not only need new ways of thinking about the world, but new ways of being in and of the world" (183). Until we heed Hamilton's call to "begin rethinking labor," we will continue to surrender the concepts of "economy," "labor," and "agriculture" to "economists," and will thus continue to see individual well-being suffer at the hands of soaring stock markets, inadequate and drudging labor opportunities, and an agricultural 
system which wastes most of the poisonous food it produces in the global North while permitting famine to grip the global South (183). For the important emerging ecocritical concern with "environmental justice" (referenced on 8 pages of Buell's article) to bear fruit, theorization of economy must take center stage.

The ecocritical directions which have demonstrated most concern with economy are bioregionalism and the new agrarianism. Indeed, Buell may be able to identify bioregionalism as one of the most enduring research areas of first-wave ecocriticism because it is so unique in its staunch practicality; as the introduction to the 2011 edited collection The Bioregional Imagination explains, "in addition to establishing a particular way of delineating place, bioregional thinking also implies a political and cultural practice that manifests as an environmental ethic in the day-to-day activities of ordinary residents" (3). Literary-critical bioregionalism in particular aims to enact this manifestation by "encourag[ing] readers to connect the texts they read with their own lives, places, and practices, [and] helping them imagine how to move, both physically and imaginatively, from the word to the world" (11). Though this is precisely the target for which ecocritical practice should be aiming, bioregional literary criticism ultimately suffers from the same stymying economic avoidance as does ecocriticism, able and eager to imagine potential modes of bioregional epistemology and politics, yet hard pressed to prescribe exactly which labors today might move us "from the [imaginative] word to the [economic] world" we actually and currently inhabit.1 The new agrarianism, by contrast, is perhaps the area of environmentalism which is both quickest to utilize economic arguments and to advocate specific economic changes.1 Yet its discourse remains too often ignored from academic environmentalism, whose urban bias remains skeptical of how agrarian arguments can be relevant to modern economic life. 
This dissertation argues that the underlying reason for ecocriticism and environmentalism's elision of economic issues is an overreliance on pastoralism as a subject of analysis, a mode of criticism, and as a paradigm of ecological consciousness. The literary and discursive mode of ecological consciousness known today as "pastoral" traces its origins back to the Aegean Neolithic Revolution that spawned the Greek city-states. Before this shift, nonurbanized hunter-gatherers depended on community ability to apprehend, interact with, and preserve as many different ecological actants as possible, and thus encouraged humans to form social structures that, though "varied in detail," were "similar in outline": hunter-gatherers are generally nomadic, egalitarian, and entwine economic labor with what we'd today consider the leisure activities of "ritual, socialization, and artistic expression" (Gowdy 237, xxi). The Neolithic Revolution changed this arrangement. The large-scale monocultural production of grain crops—which are easily stored, transported, counted, divided, and taxed—facilitated a vast shift in human social organization toward concentrated sedentary settlements administered by state structures (Scott, Against). These city-states enabled and required the emergence of an administrative leisure class freed from direct economic-ecological interaction with the environment. I use the term "leisure-class" in Veblen's sense, not to "connotate indolence or quiescence," but "the non-productive consumption of time" (46).1 The leisure class may work, but in ways administrative, religious, scholastic, or militaristic, ensuring but not directly participating in the extractive labor that produces and procures food energy from the non-human environment. Whereas in hunter-gathering societies these two modes of labor were concomitant, in urban societies they are separated. And the leisure-class' new freedom from regular extractive

1 See chapter 3 of Theory of the Leisure-Class for a full examination of its development from pre-modern to commercial society. 
labor changed their conception of environment and landscape into a paradigm we now call, broadly, "pastoral."

Accordingly, pastoral writing first emerges within the context of urbanized Greek culture, with Theocritus and Hesiod, yet achieves its classical peak in Virgil's Eclogues, which chronicle the conversations and ruminations of shepherd-poets in rural settings. 2 The politically interested Eclogues establish the defining features of the pastoral mode, including the drawing of contrast and tension between the metropolitan centers and rural hinterlands of agricultural societies, which Virgil does primarily through ruminations on the expropriation of land by metropolitan elites. This tension between city/country (and its correlates human/nature and economy/ecology) inspires the pastoral myth of a bucolic "arcadia," an idyllically peaceful and beautiful rural retreat into "nature" from the complexities and violence of urban life. The famous fourth Eclogue features a vision of a harmonious past golden age of rural idyll, disrupted at present by insidious urban forces, yet destined for future return.

The pastoral mode ebbed with urban life in the Medieval era, yet again exploded in popularity in the Renaissance, flows through Romanticism and Transcendentalism, and remains prevalent in environmentalist and nature writing of all kinds today. The popularity of pastoralism has appropriately inspired an enormous amount of critical attention; even in 1709 Alexander Pope cites the "numerous dissertations that critics have made on the subject" in the introduction to his own "Discourse on Pastoral Poetry." This critical attention continues to this day, and it is thus often noted that "there are as many versions of the pastoral as there are critics and scholars that write about it" (Alpers 8). One might add "writers" to that list, for it is indeed difficult to

2 See Ziser, "Walden" (142) and Bruno Snell (281-90) for discussion of the role of agrarian labor in the shift from Greek to Roman versions of pastoral. 
think of any British or American authors of any genre who do not at times slip into discursive formulations which could be broadly called "pastoral."

Since the pastoral mode takes "nature" as its basic theme, it has been appropriately and extensively theorized by ecocriticism, which views pastoral not only as a literary mode or discursive tradition in which a writer may participate, but as the dominant conceptual ideology through which Western human minds perceive nonhuman nature (Gifford "Pastoral"). For ecocriticism, pastoral tropes (nostalgia for a less socially complex agricultural past, the idealization of agricultural landscapes, the trope of retreat-and-return, and the ethical suspicion of urban commerce, markets, and industrialism) are more than mere characteristics of certain artistic works, but serve as the primary lenses through which Western humans conceive, apprehend, and interpret their environment. In the words of Lawrence Buell, classical pastoral writers created a "species of cultural equipment that western thought has for more than two millennia been unable to do without" (Environmental Imagination 32).

Accordingly, as Donna Landry writes, "the literary-critical response to the challenge of ecological criticism has most often been generically pastoral" (255). Indeed, the first wave of ecocriticism constructed a wilderness ethic directly drawn from the pastoral tradition. Yet the wilderness ideal was susceptible to the basic New Historicist critique of pastoral that Raymond Williams so exhaustively demonstrates, namely that the mode permits and even encourages the exploitation of the working class by eliding the harsh realities of their labor. William Cronon utilized many of Williams' key points in his famous critique of "The Trouble With Wilderness," and ecocriticism began to search for a "post-pastoral" discourse that might more fully conceive the complexities of human society. But due to the pastoral mode's expansiveness, it has proven very difficult for ecocriticism to construct an alternate and productive conception of "nature" 
which does not, to some degree, rely on the pastoral tradition. Ecocriticism found pastoral ideology to be so pervasive in Western cultural logic as to be indispensable, and shifted its focus from calls for replacement to attempts at recuperation from Williams' strain of historicist critique; Jonathan Bate goes so far as to state that "if there is to be an ecological criticism" at all, pastoral must be "reclaimed" (19). This reclamation presents a new form of "post-pastoral" that draws from the tradition yet admits a more ecocentric ontology. Terry Gifford's New Critical Idiom guide on Pastoral ends accordingly with an articulation of six qualities of a "post-pastoral" text that align loosely with Buell's foundational description of an ecocentric text. This settlement has guided ecocritical scholarship regarding the pastoral to date, and finds expression in the more recent ecocritical turns to the new materialism and environmental justice. Garrard encapsulates the critical project in the closing lines of his influential "Radical Pastoral," suggesting that "pastoral can be radical as not a finished model or ideology but as a questioning, itself a question about be/longing, the root of human being on this earth" (465).

But the problem with recuperating or revising a "post-" or "radical" pastoral is that the mode foundationally relies on the very separation of nature and culture that ecocriticism seeks to efface. This separation must thus be present in any tradition that grows from pastoral, and it is indeed within Gifford's definition of the "post-pastoral." His third principle, for instance, states that "our inner human nature can be understood in relation to external nature" (156). Here nature and culture are not simultaneous or synonymous; they remain separate concepts "in relation" to each other. One is "internal" and one "external"; they're interpenetrated and mutually reliant, but essentially different. In this way the principle does not deviate from pastoral, but reinscribes it. Michael McKeon writes that classical and Enlightenment "pastoral works both to affirm and suspend such oppositions" between nature/culture, city/country, "in such a way as to intimate 
simultaneously their interpenetration" (271). The longevity and rewarding beauty of the mode is due to its ability, when treated by a good writer, to play with this distinction to theorize a specific form of interpenetration. Yet to perform this task, even though "complex pastorals" as Leo Marx calls them, a writer must both begin with an assumption of difference, and then finally return to that difference at the end. To describe nature and culture as interpenetrating is to rely on two terms ironically defined in opposition to each other. And, as ecocriticism has demonstrated, that ontological separation causes the environmental crisis by permitting and encouraging the exploitation of nonhuman beings and dehumanized humans. To move past this, we must conceptualize nature and culture as synonymous, not as essentially different spheres nonetheless "interpenetrated."

The resilience of this pastoral separation between nature and culture is due to the mode's enmeshment with urban-industrial economic structures. Beyond merely drawing contrast between city and country, pastoral operates from the subject position of the city, musing on a typically objective "nature" from an urban perspective. As Frank Kermode notes, "the first condition of Pastoral is that it is an urban product" (14). Michael McKeon critically recognizes "how deeply pastoral discourse and material experience- that is to say, economic, social, and political experience - are implicated in one another" (267). As chapter 4 will argue, the structure of pastoral discourse and urban-industrial economics are homologous and concomitant; pastoralism serves as the dominant ideological ecological consciousness of urban societies. Pastoralism is the Modern view of nature, in Latour's sense of the term not as a time period, but as an urban orientation and mindset requiring iconoclastic construction and deconstruction (We Have Never). This is why the mode originated in Greek city states, achieved its classical zenith alongside the growth of the Roman metropolis, receded during the Middle Ages, re-emerged 
with new robustness in the early modern city centers of the European Renaissance, and today has become as pervasive and ubiquitous in environmentalist discourse as urban life has become on earth. And this is the great alteration of our time: before the 20 th-century, the urban-pastoral perspective was always a minority subject position, the privilege of the elite leisure-class. Yet as urban living has spread, so has the pastoral paradigm, and the conceptual separation of nature and culture it entails.

Pastoralism's stranglehold on environmental discourse explains the trouble ecocriticism and environmentalism face with addressing issues of economics. For, as Williams famously argues, the pastoral mode generates its romantic and idyllic view of nonhuman landscapes by eliding, or romanticizing, the exploited human labor that transforms those landscapes from nonhuman spaces into production sites for urban consumption. This is not surprising, given the central economic condition of the mode is relief from the necessity of engaging in extractive labor. As Williams writes, the very contrast of country and city "depends, often, on just the suppression of work in the countryside, and of the property relations through which this work is organized" (46). This suppression leads to what Val Plumwood terms urban "dematerialization," or "becoming more and more out of touch with the material conditions (including ecological conditions) that support or enable our lives" (141). This process is, of course, intrinsic to urbanindustrial life, from the Greeks and Romans to the neoliberal megalopolis, which alike require the import of resources from outside city limits. Pastoral discourse supports this process of economic elision in by layering on top of the nature/culture split a divide between one's "singular, elevated, conscious 'dwelling' places," or the mind, "and the multiple disregarded places of economic and ecological support," or the body. This is why, when environmentalism does address extractive labor, it is often treated as an enemy. As Richard White writes in one of 
ecocriticism's few direct explorations of work, environmentalists often "disdain and distrust those who most obviously work in nature," thus "associating work—particularly heavy bodily labor, blue-collar work-with environmental degradation" (172). As White shows, this is a flawed position, since all living humans rely on someone, somewhere, laboring to produce what they consume. But the increasing (sub)urbanization industrialization encourages obscures this reality, making it too easy for humans to conceptualize environmental destruction as something that occurs elsewhere and at the hands of others, when it is truly guided by the exploitation that is the prerequisite of middle class lifestyles. Any foray into ecocritical economics will quickly reveal an uncomfortable contradiction: the pastoral divide between nature/culture that ecocriticism seeks to transcend is economically inscribed by the industrial labor practices that enable environmentalist discourse.

Thus, ecocriticism must necessarily participate in the discursive elision of body/economy because it is itself a necessarily industrial pursuit. The discourse-labor that builds ecocriticism and advocates for environmentalist change requires vast amounts of human time and energy. Indeed, discursive interactions compose the entire working lives of professional ecocritics, activists, and environmentalist bureaucrats. Such discourse-labor can only be performed if there exists a cheap mechanism through which to obtain the material necessaries of life, such as shelter, clothing, warmth, and food. In the Middle Ages, this mechanism was a Feudal system which produced enough surplus resource to support a handful of aristocratic and clerical elite; today it is the vastly more powerful oil-fueled global corporate industrial complex. As Stephanie LeMenager notes, wealthy human populations today quite literally "live oil"; that magic deathfluid underlies every activity for which we wouldn't have time if we had to do the wash, keep warm, or transport ourselves, from the internet to feminism to, ironically, environmentalism. 
Thus, the production, dissemination, and conversation of environmentalist discourse ironically requires the oil industry. This irony is even clearer in the more direct reliance of environmentalist discourse on the institutional support of universities, governments, and nonprofit organizations on the liberal corporate model which, ecocriticism argues, employs an ontological separation of nature and culture to permit the exploitation they commit. Indeed, even enacting the regulatory reforms for which environmentalists advocate requires the continuing — and even increased!power of governmental and corporate social structures formed on the same modern model ecocriticism writes against.

So long as humans rely on urban-industrial economic systems, we will be unable to transcend the pastoral paradigm, and the negative ideological baggage that comes with it. But urbanization isn't going to disappear, even if we wanted it to. Cities are growing at an unprecedented pace, and though they entail environmental exploitation of periphery areas, they also have the potential (when designed and implemented properly) to reduce human disruption of the environment by concentrating and collectivizing negative waste byproducts of human life. Thus, despite the problematic aspects of pastoral, the economic realities of human life preclude pastoral from being transcended into the new biocentric paradigm of natureculture that ecocriticism seeks. But ecocriticism is correct that that adoption of that paradigm would indeed be revolutionary and would lead to a more realistic conception of earth's ecology that would be less harmful both to human and nonhuman communities. The problem is that ecocriticism is looking for examples of a naturalcultural paradigm in the wrong place. That paradigm is not to be found in pastoral, nor a post-pastoral, but lurks in the margins of modern human economy, discourse, and artistic production_-indeed, at the very core of pastoral thinking: in the georgic, 
which views nature not as a site of leisure, but a working, economic landscape synonymous with human culture.

II.

The georgic mode is closely related to pastoral, and also traces its origins back to classical Greece and Rome. Hesiod's Works and Days is perhaps the first recorded instance of georgic writing, focusing on the economic lot of man as a creature born to labor. But the "georgic" takes its name from the second of Virgil's great poems, written as a transition between the pastoral Eclogues and heroic Aeneid. Virgil's Georgics bear many tonal and topical similarities to his Eclogues, both poems presenting romanticized depictions of peaceful rural life. But whereas the pastoral Eclogues concludes that amor omnia vincit (love conquers all), the Georgics claims instead that labor omnia vincit. And accordingly, the Georgics linger less in appreciation of nonhuman beauty by speakers at otium, or leisure, and more in the realm of negotium, or work. Virgil's Georgics are arranged accordingly into four books focusing on the beauty and method of extracting human energy from vegetable crops, trees, livestock, and bees. The Georgics actively inspires readers to value and participate in these economic arts that materially connect the human speaker to his environment, and instructs them in how to do so. In these rhetorical goals that the Georgics move beyond a mere literary mode, but into an economic one.

Like the pastoral, the georgic rose and fell in popularity through the centuries-enjoying a notable surge during the era of agricultural improvement in 18th-century Britain-yet it has always been overshadowed by the pastoral in the literary world. Recent literary scholarship has reflected this pattern, with countless books and articles dissecting the formal operations and historical import of pastoral discourse, yet very few addressing the georgic. When georgic is 
mentioned in scholarly treatments of pastoral, the two are often conflated, with the georgic constructed as a subset of pastoral concerned with labor, rather than a separate mode with distinct formal structures and ideological concerns. Williams, for example, discusses Virgil's Georgics and Eclogues conterminously, citing various examples from both in service of his larger argument regarding pastoral. As georgic scholar Michael Ziser writes, "rarely have the distinctions been spelled out with precision" (178). Ecocriticism has reproduced this critical trend; whereas the most seminal ecocritical studies take pastoral as their primary focus, the georgic has been the subject of merely one major ecocritical book, Timothy Sweet's American Georgics. Just as ecocriticism's pastoralism leads it to elide issues of economics, so too it neglects its georgic relative. This neglect has led to inadequate appreciation of the key formal and historical role the georgic mode plays in the construction of pastoral discourse and the urban economic systems it supports.

Sweet, one of the few ecocritics to attempt a more precise articulation of the relationship between georgic and pastoral, writes that the georgic "treats those aspects of pastoral, broadly construed, that concern not the retreat to nature or the separation of the country from the city, but our cultural engagement with the whole environment" (5). This "engagement" is essentially the intersection of economy and economy, in the way humans manage and sustain the extraction, transformation, and consumption of energy from "the whole environment." Whereas pastoral discourse is a product of an essentially urban, leisure-class perspective, the georgic mode is informed by and participates discursively in the material performance of the extractive labor that sustain urbanism; it is the discourse of the farmer, hunter, miner, and builder. The ecological consciousness of the two modes share much in common (a divine appreciation for rural landscapes, an anti-urban bias, a myth of a lost Eden) and are not mutually exclusive, with texts 
and speakers often shifting easily between the two discourses. Where they diverge, however, is in their economic origination and orientation: whereas pastoral conceptually separates human economic culture from nonhuman ecology, the georgic is concerned centrally with their method of interpenetration. Through the millennia of urban history in the West, these dual economic and discursive subject-positions existed in tandem, informing, reflecting, and fluidly interpenetrating each other, colluding to produce various settlements of socio-economic stability between the laboring and leisure classes. And, together, the modes provided Western communities a consciousness of environment that guided their urban socio-economic development.

Yet the technological advances of the industrial revolution have rendered georgic discourse less necessary to human economic survival, and its prevalence has declined within the human experience. As the social pursuit of agriculture, which once required masses of human workers participating in georgic discourse, is taken over by machines, those workers move to cities and adopt the pastoral perspective concomitant with urban lifestyles. Whereas in the premodern era the vast majority of humanity viewed earth through a georgic lens, and a pastoral paradigm was the privilege of the leisured few, modern urbanization began to invert this prior

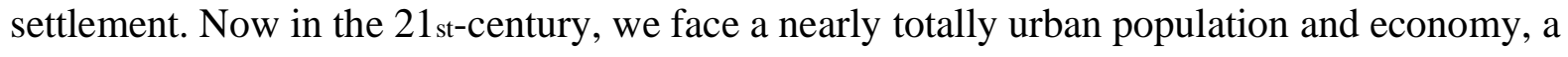
new world order in which the pastoral paradigm dominates. No corner of today's earth remains un-urban, nor un-industrialized. Even the most remote locations are affected by climate change, are immediately accessible via helicopter, and possess digital discursive connections to the cultural capitals of New York, London, Beijing and Jerusalem. In the words of David Orr, "the urban-industrial mind [is] now triumphant virtually everywhere" (95). Georgic discourse has not disappeared — it is still present everywhere people practice agriculture — but it has been transformed from the dominant mode of environmental discourse into a decidedly marginal one. 
As Ziser writes, "it is with this collectivization and sequestration of agroecological writing" into elite scientific, industrial, and corporate networks "that the balance began to tip decisively toward the pastoralist understanding of the natural world as inert backdrop that characterized most late-nineteenth and twentieth-century environmental representation" (Early American 21).

This pastoralization of the human population has enabled human communities to idealize and ignore the manner and extent to which their economy is dependent on both underlying environmental conditions and the labor - whether fossil or human-powered - that extracts it. The devastating industrial economic processes that simultaneously support cities and form the main causes of pollution and climate change, from the perversities of industrial animal farms to mountain-top removal mining, can only be permitted by a human population with widespread economic ignorance, whether it be innocent or willful. And these industrial economic processes are imaginatively underwritten by the ascension of pastoralism, and the elimination of georgic discourse.

This dissertation argues that to address the imaginative and economic problems of urbanpastoralism, we must Recall the Georgic. In the conceptual realm, popular recollection of the georgic is needed because the mode assumes, embodies, and expresses the natural-cultural connection that ecocriticism seeks. Georgic discourse is important to maintaining an ecologically sustainable human social relationship with earth because it is foregrounded in a basic understanding of and preoccupation with ways in which the human and nonhuman beings are connected at the nexus of ecology and economy. In this sense, georgic does not recognize economy and ecology as separate, yet interpenetrating realms, but as simultaneous; it witnesses in its labor an ecological-economy. My chapters will all elaborate this key lesson of the georgic: that humans are nature, and that economy is ecology. 
Yet the most important reason we must Recall the Georgic is its central concern with recommending ecological-economic actions. Too often does the pastoralist paradigm of environmentalism push off economic theorization. In Lance Newman's words, ecocritical practice "suffers from the weaknesses of the postmodernist tradition it extends," namely that "it is so willing to see performing radicalism, thinking difference, or renarrating history, not just as necessary but also as sufficient forms of political action" (17). The georgic mode is wellequipped to remedy this deficiency due to its transdisciplinarity: in conceptualizing systems of ecology, economy, and culture as concomitant, the georgic necessitates the performance of cultural criticism in the material, economic arena. Georgic, unlike pastoral, is not a pursuit of the spectator, but of an economically engaged laborer; it demands action. In Ziser's words, "the georgic asks not [the pastoral question of] whether language can successfully jump up from a real original to an imitation, but how it can jump down from abstraction and land with a degree of efficacy upon some object in the world, becoming not just a mirror of nature or a lamp, but something more akin to a hoe or a shovel or a seed drill 'of nature'" (183). Georgic can thus help academic scholarship, and environmentalism more broadly, enter the arena of material application by recommending, experimenting with, and participating in sustainable, appropriate, and just methods of human life. In this sense, georgic (both generally, and specifically in this dissertation) participates in the disciplinary area of ecological economics, and performs Latour's call for a "compositionist" research that moves beyond critique in seeking not merely to imagine, but to compose a better world.

III.

To make this argument, this dissertation presents a literary history of the relationship between georgic and pastoral from the beginning of the industrial revolution to its culmination in 
our modern, urban, globalized society. Methodologically, I assume that most Western texts reflect, in reference to nature, modal patterns that can be characterized through analysis as belonging to pastoral and/or georgic discourses. Building off of the New Economic Criticism, which finds a structural homology between systems of discourse and culture, I contend that what determines a community or individual's articulation of the pastoral or georgic mode is primarily their mode of ecological-economic interaction with the nonhuman world, i.e. their style of labor.3 Whereas georgic discourse is borne of participation in labors extracting human energy from environment, pastoral discourse is inculcated by leisure-class, urban-industrial economic engagements. Because writing literature requires ample leisure time, it must to some extent derive from and participate in pastoral discourse; georgic discourse more frequently takes the form of oral conversation and technical writing. Because my argument seeks to characterize the relation between the two discourses, I will analyze crossover texts: literary works that contain georgic perspectives attained by the author's participation in agrarian labors. The authors I study are thus hybrid figures, engaging simultaneously in pastoral and georgic discourse, and revealing within their literary output the way the two modes interact and constitute each other in various socio-ecological contexts. My analysis follows the ascendance of pastoral ecological consciousness with the spread of urbanization, and the simultaneous gradual forgetting of georgic discourse as extractive human labor is replaced by fossil-fuels.

Because my narrative focuses on the effects of industrialization on ecological consciousness, I begin, as did the revolution, in Britain. Robert Burns crafted his poetry in the precise decades that his native Ayrshire, Scotland underwent "improvement," quickly shifting from an agrarian, late-feudal society to an urban-industrial one. Inspired by his work as a farmer

3 See Heinzelman and Goux on the New Economic Criticism. 
and the moral-economic theories of his contemporary Adam Smith, Burns' poetry demonstrates both the feudal settlement between the pastoral and georgic modes, and how that relationship was troubled by the increasing dominance of the pastoral mode upon which improvement and industrialization relied. Burns' mixing of the pastoral and georgic modes resulted both in his incredible popularity with both the working and leisure classes, and the formal and topical innovations of his poetry, which use georgic tones to critique the pastoral conception of nonhuman nature.

Chapter two turns to the American experiment, which was spurred by Britain's industrial turn, yet also rose in resistance to it. I focus on the writer-farmers Thomas Jefferson and J. Hector St. Jean de Crèvecoeur, who sought an agrarian bulwark against what they correctly foresaw to be the ultimately totalitarian project of urban-industrialism by institutionalizing georgic discourse in agrarian political policies. After surveying the ways georgic and pastoral discourses were enmeshed in the ecological-economy of early America, I turn to Crèvecoeur as the most complex representative expression of the agrarianist thrust of early US development. I argue that his Letters From an American Farmer and Sketches of Eighteenth-Century America reveal an early American agrarianism conceived as a reactionary socio-economic response to the rise of industrial commercialism in Britain. Crèvecoeur demonstrates the egalitarian promise of an agrarian vision, yet also displays the ecological-economic weaknesses that led to its decline, and continue to plague its modern practitioners: the impossibility of achieving the ideal of selfsufficiency, the rhetorical strength of the commercial lures of luxury and leisure, and the necessity of a paradoxically strong, yet distant government to protect against exploitation.

Chapter three examines the role of georgic and pastoral discourse in the next significant U.S. articulation of agrarian philosophy, in antebellum New England. Agrarianism is a 
significant, yet neglected component of Transcendentalist social reform, with utopian projects like Brook Farm, Walden, and Fruitlands all intended as material expressions of Romantic antiindustrial postures. I argue in a reading of Hawthorne's Blithedale Romance that the movement was often limited by an over-investment in pastoral thinking that emphasized agrarianism's utopian and recreational inflections, over a georgic focus on the shape of labor. Thoreau's Walden, by contrast, achieves the pinnacle statement on American agrarianism by utilizing the georgic mode in its overriding concern with ecological-economy. Thoreau recognizes that from within an already industrialized landscape, effective agrarian activism requires georgic attention and care for one's labor and expression of ecological-economy.

This is because, as chapter four reveals, participating in industrial economic activity inculcates a pastoral ecological consciousness that encourages environmental devastation by conceptually separating the realms of nature and culture, economy and ecology. To make this argument, I turn to America's greatest poet of urban industry, Carl Sandburg, whose work reveals this dynamic in its reflection of the spectacular industrial transformation of the upper Midwest. This chapter reveals the essential problem of environmentalism in the urbanized 21 st-century: we are seeking an ontological reunion of nature and culture within an economic system that perpetuates their separation. 4

The final chapter argues that for environmentalism to achieve its needed economic bite, it should incorporate an activist georgic agrarianism. Ecocriticism's pastoralist tendencies have too long ignored the vibrant "New Agrarianism" working toward such reforms throughout the United

4 A book-length treatment of this dissertation's topic requires the addition of three crucial chapters before the conclusion: one on the role of race and slavery in the American agrarian tradition, one on the role of women and feminism, and - most importantly of all — a final chapter on American Indian georgics, which must be synthesized with settler paradigms to realize any meaningful 21 st-century agrarianism. 
States and beyond. I draw from this tradition to articulate various recommendations for Recalling the Georgic in today's social context, yet they all work toward the basic goal of bringing the practice of agriculture, and georgic discourse, back into the fabric of our living communities. In agriculture, we must move away from industrial modes of production and to biointensive, regenerative permacultures; this shift can be facilitated with policy recommendations drawn from the field of ecological economics, some agrarian strands of which advocate a relocalization of capital, and commercial reorganizations into bioregional networks. The humanities can assist these changes by using the georgic mode to reclaim theorization of ecological-economy from socalled professional economists, aiming the same critical strategies we use to problematize categories of race and gender toward imagining ecological-economic futures that entail better living for all beings on earth. 


\section{Burns and Georgic at the Industrial Turn}

The understandings of the greater part of men are necessarily formed by their ordinary employments.

\section{Adam Smith, The Wealth of Nations}

I'm truly sorry Man's dominion

Has broken Nature's social union

An' justifies that ill opinion,

Which makes thee startle

At me, thy poor, earth-born companion,

An' fellow mortal!

Robert Burns, "To a Mouse"

Robert Burns was born in 1759, on the cusp of the economic modernization of his native Ayrshire, a region of rich soil and rolling hills on the lowland west coast of Scotland. Though agricultural improvement, and the broader Modernization accompanying it, occurred unevenly and haphazardly across Europe, it was delayed in Scotland, finally overtaking Ayrshire at a particularly rapid rate from 1760-1800, a period overlapping precisely with the poet's lifetime. As a leisure-class poet, Burns was intimately familiar with trends in georgic and pastoral literature from antiquity through the early modern period, and as a working farmer, Burns witnessed and implemented the social changes wrought by improvement, both discursively and materially. Burns is thus a useful figure to help us work through the precise and changing relationship between pastoral and georgic early in this study.

Specifically, Burns' poetry reveals how the pastoral and georgic's differing conceptions of environment are shaped by ecological-economic activity, and also depicts the way agricultural modernization changes the classical relationship between them. Burns' "Afton Water" reveals a pastoral vision of nature as a slumbering, femininized, and exploitable beauty separated from human economic endeavor. His agricultural poems, such as "Poor Mailie" and "To a Mouse," employ an ecological version of the georgic mode that finds the natural-cultural connection that 
ecocriticism seeks by recognizing nature as a cultural space, and economic decisions as ecological ones. Though Burns was no political reformer, his poems do correctly foresee that improvement and urbanization require the ascension of the pastoral over the georgic, and warn against the socio-ecological consequences of that shift. One of his only urban poems, "The Brigs of Ayr," asserts the importance of preserving the georgic mode both discursively and economically, to create a better modernizing process driven by synthesis of the two modes of environmental conception.

I.

Lowland Scotland experienced the process of improvement relatively late. 5 The traditional medieval practice of runrig cultivation - in which rural communities rotated use of the best strips, or rigs, of land - remained largely unchallenged until the Union of 1707, when English agricultural innovations began to be imported by the Scottish nobility. Scotland thus underwent similar processes of enclosure and capitalization as England, yet, benefiting from the example of the English, at a more deliberate and faster pace. Tom Devine writes that "the pace of urban and industrial expansion in late eighteenth-century Scotland has been acknowledged as among the fastest in western Europe" (35). Rather than England's protracted and gradual transition to commercial urban society, lowland Scotland experienced "a basic discontinuity on trend," with abrupt and widespread enclosures and adoption of agricultural improvements in the decades after 1760 leading to vast expansion in that urban "sector of the population which did not produce all its own food from its own resources" (35). Rents moved swiftly from in kind to cash, as "the market penetrated all aspects of the social and economic structure" (44).

5 See Kerridge and Overton for a full historical treatment of agricultural improvement across Britian. 
Scotland's economic transformation occurred against a literary backdrop in which both the pastoral and georgic modes were dominant. Because pastoral writing depends on an urban foil, it ebbed in the Middle Ages, yet enjoyed a widespread recovery across Europe as Renaissance cities rose and flourished. Critics such as Raymond Williams, Ordelle Hill, Andrew McRae, and many others have charted the pastoral's early modern rise, operating under the general New Historicist assumption that the two modes assisted in agricultural improvement by providing "an effort at social and political understanding" (Feingold 2). As improvement progressed and spread across the space-time of early modern Britain, the literary representation of agrarian England shifted "from a site of manorial community and moral economy toward a modern landscape of capitalist enterprise" (McRae 7). In pastoral poetry, this was accomplished by retaining the celebration of rural spaces as "an arena of recreation and rejuvenation," but by redefining those landscapes specifically as enclosed, private property (McRae 269, 279).

While urban poets were creating these idealized pastorals of post-feudal rural felicity, landowners and laborers across rural Britain were busy constructing the material landscape upon which those pastorals were based with labor and discourse in the georgic mode. Anthony Low chronicles a late sixteenth-century Georgic Revolution that fueled, directed, and explained improvement by countering the courtly aristocratic ideals of leisure (and disdain for work) present in Tudor and Elizabethan poetry. Low argues that seventeenth-century writers found georgic the ideal literary form to inspire and chronicle the nation-building ambitions of early modern Britain. Georgic supported the rising middle-class of small landowners tasked with directing, and improving, production on newly enclosed tracts. The influential 1697 publication of Dryden's translation of Virgil's Georgics, complete with a laudatory introduction by Addison, further elevated the georgic, which reached a subsequent zenith in Burns' eighteenth-century, 
when, as Kurt Heinzelman writes, "the popularity of georgic poems rivaled that of prose forms the age also demanded: didactic works like sermons, instructional works like travel guides, and treatises on political economy - the whole textual infrastructure dedicated to 'improvement'" (182).

Writers in eighteenth-century Scotland contributed their own pastoral and georgic literature to these broader trends. Arguably Scotland's most popular and influential pastoral text of the era was Allan Ramsay's verse drama The Gentle Shepherd, which applies Scots dialect and setting to the conventional form of Virgilian pastoral. Yet Ramsay, and other poets such as Robert Fergusson, were keenly attentive to Scotland's modernization, and sought to participate in the imaginative construction of the new, "improved" nation through their poetry. As Soren Hammerschmidt writes,

pastoral developed in the late seventeenth to early eighteenth centuries into a preferred poetic mode for the representation of [urban] concerns. Outwardly portraying a more or less idealized view of the lives and loves of shepherds[,] pastoral implicitly renegotiated the boundaries of urban and rural spaces. At the same time, it developed as a means for city-based writers to critique their environment by contrasting it with a supposedly simpler, more natural life in the countryside. (80)

With poems such as Ramsay's "Edinburgh's Address to the Country," or Fergusson's "The Town and Country Contrasted," eighteenth-century Scots writers used the inherent tension within pastoral between country and city to imagine the cultural consequences of economic modernization, and imported Scots dialect into their poems to ensure that the progress of Scottish "improvement" maintained traditional Scottish mores. Scottish writing in the georgic mode also shared this concern. Adam Dickson found popular English agricultural manuals to be ill-suited to 
the environmental context of Scotland, and published his Treatise on Agriculture in 1762 as a corrective. The Scottish expat William Grainger published perhaps the most famous eighteenthcentury georgic, The Sugar Cane, two years later. Adam Smith, however, was likely the most influential georgic writer of the century, with his 1776 Wealth of Nations drawing from the example of Scottish improvement to theorize modernization across the globalizing world.

Born in 1759, Burns' lifetime overlaps precisely with Ayrshire's improvement, and his poetry's thematic concerns with issues of class, environment, and economy render it a particularly useful contemporaneous record of the transformation to a modern industrial economy. Far from the "heaven-taught ploughman" Burns is often thought to be (and as he often presented himself), Burns was highly literate, and intimately familiar with the classical and Enlightenment canon of poetry, philosophy, and agricultural writing. Though indeed a "ploughman" at times, this was far from Burns' exclusive occupation. He and his family were tenant farmers, and thus roughly middle-class. His father, and then Burns himself, managed a series of farms ranging from 70 to 170 acres, an occupation requiring drudging manual labor, but also considerable professional skill and the social faculties of interacting with both the landed gentry and lower-class laborers, skills that would serve Burns well in his later successful quests for patronage from the Edinburgh gentry.6 Yet Burns remained a farmer through the first thirty years of his life, and was thus directly responsible for enacting many of the prescripts of the "new husbandry." His letters abound with details of his attempts to implement the improvements he read in the prose georgics of Jethro Tull and Adam Dickson, and even the travel journals he wrote after his farming career ended survey landscapes with the agriculturalist's eye (McGinty 120, 132). Nigel Leask's 2010 Robert Burns and Pastoral documents and analyzes Burns'

6 See Leask 18 for a more thorough description of Burns' social and professional class. 
interaction with the Scottish agricultural revolution, arguing that his "poetry owes its very existence, as well as its phenomenal success, to Burns' engagement with 'improvement'" (4).

Burns' vision of ecology and economy was particularly influenced by his favorite prose writer, Adam Smith.7 Burns read and recommended both his 1759 Theory of Moral Sentiments and 1776 Wealth of Nations with great admiration, commenting in a letter that "I could not have given any mere man, credit for half the intelligence Mr Smith discovers in his book" (McGinty 66). Smith's writing shares several of Burns' key concerns. Both were responding to the economic modernizations of urbanization and industrialism that they were witnessing across Scotland and beyond, and both were interested in the role of nature, labor, and psychology in those processes. As Ted Benton writes, Smith conceptualizes "wealth as the annual produce of 'land and labor.' ... [W] hat Smith calls 'the spontaneous productions of nature' can meet no human need or desire unless some human labor is performed" (144). For Smith, it is the interface of humanity and the environment at the nexus of labor that generates the Wealth of Nations.

Late in Nations, Smith warns of the "educational" consequences of the industrial turn. Smith recognizes that "the understandings of the greater part of men are necessarily formed by their ordinary employments" (734). It is one's daily, repeated, habitual, occupational labors, then, that inculcate the contours of individual consciousness. And the "progress of the division of labor" that produces industrial economic relations fundamentally changes our mode of work, and thus our fundamental ontological orientations. Smith writes that in pre-industrial "barbarous societies, as they are commonly called, of hunters, of shepherds, and even of husbandmen in that rude state of husbandry which precedes the improvement of manufactures and the extension of foreign commerce, $\ldots$ the varied occupations of every man oblige every man to exert his capacity

7 See McGinty for a full appraisal of Burns' engagement with Smith's work. 
and to invent expedients for removing difficulties which are continually occurring" (735). This is due largely to pre-industrial agriculture's dependence on complex local environmental contexts, which demands a wide scope of attention to and breadth of knowledge of various environmental, social, economic and political contingencies. In contrast, industrial labor is untethered to local ecological context and highly divided, leading workers to specialize in merely one or two operations necessary to the ultimate production of, say, pins, as goes Smith's famous example. Smith warns that in this new system, the worker "has no occasion to exert his understanding or to exercise his invention in finding out expedients for removing difficulties which never occur. He naturally loses, therefore, the habit of such exertion, and generally becomes as stupid and ignorant as it is possible for a human creature to become" (734).

Burns extends Smith's analysis to the ecological realm, harnessing the pastoral and georgic modes to explore the shift from pre-modern to industrial society with more nuanced attention to its effects on environmental consciousness. For, as Benton writes, the modern turn was also ecological: "Nations was written on the verge of a thoroughgoing 'disembedding' of wealth-production from its specific ecological conditions and contexts" (145). The shift in labor from rural-extractive to urban-manufacturing changed the way the great mass of people viewed the environment. Burns, as a middle-class worker of both land and words, is more familiar than Smith with the immediate physical and psychological effects of the shift, and his poetic mode is able to convey them in more nuanced terms than Smith's theoretical prose. Burns' poetry shows how environmental perspective is built from one's habitual material interactions with nonhumans, from mode of labor. 
II.

Despite the clearly environmental themes in his poetry, Burns has been neglected by ecocriticism, which has turned instead to John Clare and Robert Bloomfield in studies of British Laboring Class Nature Poetry or Romanticism and Rural Community.8 Clare in particular has been anointed the prime example of working-class conceptions of nature during British improvement, featuring prominently both in the above studies and the touchstone ecocritical treatments of British literature by Johnathan Bate and Timothy Morton. Clare's ability to enliven nonhuman matter renders him an important ecological poet, and his description of enclosure, which "came and trampled on the grave / Of labour's rights and left the poor a slave," is incisive and illuminating ("The Mores" 19-20). Yet as a farm laborer, Clare lacked the economic knowledge, interest, and responsibility that Burns used to imbue his poems with georgic concerns. Clare's agricultural poetry, accordingly, is heavily pastoral; his "Haymaking," for instance, captures the "happy shout—and song between" of that particular midsummer labor's satisfying cooperative dance, yet lingers in haymaking's times of "leisure," while "swain and maid / Lean o'er their rakes and loiter in the shade," thus eliding the job's brutal requirements of carrying endless heavy stacks of hay from field to cart, cart to shelter, all in the summer sun (711). The haymaking exposition of Burns' "Country Lass," on the other hand, begins with a pastoral setting "in simmer, when the hay was mawn, / ... / And roses blaw in ilka beild!," yet then shifts to a thoroughly economic conversation between two women of whether marrying for agricultural wealth, or "plenty," "beets the luver's fire" $(1-4,16)$ Unlike Clare, Burns connects his

\footnotetext{
8 Burns is also critically neglected in a general sense, largely because the breadth of his appeal and the hybridity of his style renders clear appraisal difficult. An unclear sense of where Burns "fits" into modern literary-historical narratives, has led to, as Leask puts it, his "academic eclipse in university departments over the last fifty years" (Bentam 207, Leask 2).
} 
ecological vision with economic issues, mixing the pastoral and georgic modes within and between his poems to, as Gerard Carruthers puts it, "question the boundary between the spheres of nature and of humanity" (10).

The ecological-economic blending of Burns' poems render him particularly relevant to critical debates surrounding pastoral, which often reinscribe Williams' critique by themselves eliding the material basis of pastoral discourse in non-extractive habits of labor. The literaryhistorical analysis of pastoral and georgic by New Historicist critics like Williams, McRae, and Low is attentive to the interpenetration of the two modes with political and socio-economic processes of capitalist improvement—as McRae puts it, "the politics of poetic landscape"—yet it does not recognize nor examine the centrality of ecological conception to the georgic and pastoral paradigms (262). Ken Hiltner's 2011 What Else is Pastoral? seeks to address this deficiency by plumbing environmentalist themes in Renaissance pastoral. He notes that "In the 1980s Sessions and Low interpreted georgic, as Alpers and Patterson did pastoral, as having much to do with politics and little to do with actual landscapes" (163). As a result, even Low's Georgic Revolution "largely fails to take into account the underlying agricultural component (and hence environmental implications) of [the] versions of pastoral and georgic" it studies (162). The extensive ecocritical plumbing of pastoral as a form of environmental consciousness has done much to alleviate the absence of ecological context in pastoral scholarship, yet it retains the pastoral's conventional elision of the ecological-economic nexus. Burns approaches ecological-economy directly in his depiction of how georgic and pastoral discourse are inculcated by labor and leisure-class economic activity, respectively.

One manifestation of pastoral scholarship's reluctance to engage with the nexus of economy and ecology is its common reluctance to discuss literature featuring rural labor as 
"georgic" at all. Whereas there have been volumes and volumes written on the pastoral, there is relatively little scholarship on the georgic. And despite the close relationship between the two modes, pastoral scholarship typically mentions georgic only in passing reference. Leask is reluctant to discuss even Burns' work as georgic, insisting that his "poetic aspirations follow the Eclogues rather than the Georgics" because of his deeper regard for the leisurely otium of a shepherd than the laborious negotium of a landowner (54). Leask quotes Addison's preface to Dryden's Georgics to defend his distinction, which states that "tho' the scene of both [pastoral and georgic] lies in the same place, the speakers of them are of a quite different character, since the precepts of husbandry are not to be delivered with the simplicity of a ploughman, but with the address of a poet" (53). Where Burns' poetry veers from the idyllic to address the realities of rural work, Leask thus follows recent critics of pastoral such as Barrell, McKeon, Williams, and the Americanist Leo Marx in labelling them "hard pastoral" rather than the proper georgic of upper-class landowners (51).

Theorists often perceive the pastoral mode rather than georgic because they tend to read labor as a type of engagement with human society, rather than engagement with the wider ecological-economy. Thus, for Leask and Addison, the agricultural prescription that centrally characterizes the georgic mode must emit from an upper-class speaker with the social authority to enact such changes upon the social unit of a given landscape. Yet if we regard that agricultural prescription as pointing toward ecological work, the speaker's authority rests not in his position within human social society but in his relationship to the land. An ecological definition of georgic, then, demands only that its speaker must seek realism in his celebration of extractive work, and address and prescribe specific practices of labor. By neglecting their ecological components, Modern critics themselves pastoralize certain literary works, such as Burns' poetry, 
which draw the aesthetic power that drives their widespread popularity among the working classes from an engagement with ecological-economy that's more properly georgic in cast. And ultimately, any scholarly examination of either mode needs to treat them together, because the perspectives of pastoral and georgic are as intertwined discursively as the leisure and labor classes are entwined economically. As Donna Landry recognizes, "the georgic ethos rewrites the pastoral as fantasy, and itself as pragmatic reality, but it cannot exist without feeding on the very pastoral it repudiates" (254). The "hard-pastoral" that Leask, Williams, Marx, and others label realistic literary depictions of rural work, is achieved by holding "pastoral and antipastoral moments together in the georgic" (253, emphasis added).

Burns is able to illustrate this arrangement because of his unusual position of professionally spanning both the pastoral and georgic perspectives. The following section will read several of Burns' poems to explain first the pastoral consciousness borne from leisure, then the georgic conception of nature wrought by extractive work. Finally, I will interpret Burns' assessment of the two in his urban poem, "The Brigs of Ayr." III.

"Afton Water" is one of Burns' most enduring and entirely pastoral poems, and demonstrates how the mode creates idyllic rural scenes by underwriting them with cloaked exploitation enabled by economic alienation. Burns introduced the 1789 poem in a letter by claiming "a particular pleasure in those little pieces of poetry such as our Scots songs, \&c. where the names and landskip-features of rivers, lakes, or woodlands, that one knows, are introduced.I attempted a compliment of that kind, to Afton, as follows: I mean it for Johnson's Musical Museum" (Letters 357). Intended as a "little" poem emulating pastoral "landskip" poetry, and to be published outside of his own volumes, "Afton" is thus one of the few pieces in which Burns 
eschews georgic tones in favor of a purely pastoral approach, rendering the sketch a valuable window into his conception of how the latter mode operates. The brief, six-stanza poem is sung from the perspective of a shepherd overlooking the river Afton, where "daily I wander as noon rises high, / My flocks and my Mary's sweet Cot in my eye" (11-12). The first marker of the poem as pastoral is its elision of the speaker's labor, and the economic context of the rural scene he evokes. The speaker is ostensibly a shepherd, yet the focus of the poem is away from his work, upon praising the beauty of various elements of the landscape, including birds, surrounding fields and woodlands, and of course the river itself. The poem's indication of the various possessors of this landscape further generates the pastoral mode. The subject of the poem, the river, is marked to own the agricultural fields surrounding it; the poem begins "Flow gently sweet Afton among thy green braes," and continues with "...thy neighboring hills, "...thy banks and green vallies below" (1, 9, 13 emphasis added). These "green" hills and vallies are cleared pastureland, whose human ownership in the context of Burns' Ayrshire is surely of pressing current political and economic concern. Yet despite the pastoral speaker's likely interest in these matters as an active farmer of that landscape, his song turns away from such worries to a bucolic idyll, a false reality in which the river, rather than posturing landowners, possesses the land.

In this fantasy the speaker himself owns but two items: "my flocks and my Mary" (12). Mary is a common character in Burns' poems, and is generally thought to be based on Mary Campbell, one of Burns' young lovers who died early in their courtship. Indeed Burns wrote in a letter that he and Mary planned their engagement "in a sequestered spot by the Banks of Ayr, where we spent the day in taking farewell, before she should embark for the West Highlands to arrange matters for our projected change of life." Yet "Afton Water"'s pastoral mode erases the 
economic nature of that meeting, as in the song Mary is "asleep by thy murmuring stream," "her snowy feet" dipped in the river, "as gathering sweet flowrets, she stems [its] clear wave" (19-20). Mary is here literally immersed in the river, and metaphorically conflated with it. Her slumber emphasizes the speaker's lone ability of consciousness, rendering his entire surrounding environment passive objects to be voyeuristically consumed, as his "wander" from the "neighboring hills" lands him eventually beside the sleeping woman, as "the sweet scented birk shades my Mary and me" (17). Veblen argues that the first marker of the development of a leisure class is the institution of private property, with women typically being the first object over which ownership is asserted (33). In the speaker's retreat from the realities of his workday, he is transformed from georgic laborer to a life of pastoral leisure by asserting subjective possession over an objectified Mary, and by extension, the landscape with which she is associated.

The effect of the pastoral song is to lull the reader also to sleep. Sung in F major, set to $3 / 4$ time, and to be delivered "slow and tender," the tune's effect is rather like a pleasing lullaby, the rhythm of the melody mirroring the rushing of the water to pacify both Mary and the reader, to lose themselves both in the "dream" of idealized natural beauty nestled within, yet separated from, the commercial agricultural realities surrounding it. Indeed, the speaker's repeated command to nonhuman nature is to refrain from incurring upon this dream by waking Mary, perhaps both to her own noontime labors, and to the sexualized gaze of the poet. For "Flow gently sweet Afton" is both an observation and a command to "disturb not her dream" (1-4). The poet also asks "Thou stock dove," "Ye wild whistling blackbirds," and "Thou green crested lapwing" to "thy screaming forbear, / I charge you disturb not my slumbering Fair" (5-8). Fair, according to the Dictionary of the Scots Language, refers directly to the "beautiful, handsome, or 
pleasing form of appearance" of Mary, but also to "a periodic occasion of buying and selling"; for Burns' speaker to remain in his non-commercial retreat, the Fair must remain at "slumber." Notably, it is nature itself - the river and birds—which both lull Mary to sleep, yet also possess the power to awaken her to the non-idealized realities of the true ecological economy in which she is enmeshed. Whether Mary remains in a pastoral slumber, or awakes to georgic realities, depends upon the mode in which the landscape is apprehended by the speaker. And, in the pastoral mode that "Afton" imitates, Mary appropriately remains asleep at song's end.

The main thrust of Burns' poetic career attempts to trouble the pastoral conventions he imitates in "Afton." Burns demonstrates critical understanding of pastoral's conventions and orientation toward nature in his early "Poem on Pastoral Poetry." Though not published until after his death, the poem was one of Burns' first, written sometime in 1785-6 as he was compiling his debut Kilmanaroc volume (Kinsley 82). Burns here draws a distinction between, roughly, good and bad pastoral poetry. "In chase o' [the former], what crouds hae swerv'd / Frae common sense ... / ... / Scarce ane has tried the shepherd-sang / But wi' miscarriage" (2-12). Burns shows himself well-versed with the famous practioners of pastoral poetry through the ages, and dismisses much of it as so idealized as to be superficial, unable to capture the true spirit of rural life. For Burns' speaker, Virgil's songs are "no herd's ballats," and "Squire Pope but busks his skinklin patches / O' heathen tatters: / I pass by hunders, nameless wretches, / That ape their betters" (15-24). The poem utilizes Scots dialect and the traditional "habbie stanza" to, as Leask argues, make "exceptionalist claims for the poetry of Scottish common life, and the realist pathos of the Scots idiom and rural landscape, against the Arcadian pastoral model" in whose wake "Afton Water" lies, and which Burns satirizes in his letters as containing characteristic "verdant fields," "budding flowers," "chrystal streams," "\& a love story into the bargain" (Leask 
47). "Honest Allan!" Ramsay is for Burns' speaker the "ane" "match" of Theocritus, whose version of pastoral excels by addressing the common character of rural life:

Thy rural loves are nature's sel;

Nae bombast spates o' nonsense swell;

Nae snap conceits, but that sweet spell

$$
\text { O' witchin love, }
$$

That charm, that can the strongest quell,

The sternest move. (32-54)

Burns argues that Ramsay's pastoral succeeds by focusing on "nature's sel," stripped of "snap conceits" and spoken through a rural narrator "bewitched" by nature's "love[ly] / charm," rather than presenting images imaged by an urban spectator that would appear "nonsense" to an actual rural laborer. Burns indicates his desire to "kindle at [Ramsay's] flame" in the preface to his Kilmanaroc volume, which begins by stating that "The following trifles are not the production of the Poet, who, with all the advantages of learned art, and perhaps amid the elegancies and idleness of upper life, looks down for a rural theme, with an eye to Theocrites or Virgil" (3). Instead, Burns claims his poems as "the little creations of his own fancy, amid the toil and fatigues of a laborious life." In this his first introduction to the national literary scene, Burns positions his poetry as presenting a realistic correction to the leisurely pastoral imaginings of urban writers, one which he undertakes by incorporating elements of the georgic mode.

Burns' agricultural poems develop a georgic vision that uses realistic descriptions of rural economy to portray nature as a conscious, cultural space ecologically enmeshed with human society. Burns achieves this vision most comprehensively in his well-loved animal poems, which are typically based on his own experiences interacting with the various nonhuman inhabitants of 
his farms, from barley and daisies to mice and lice and "The auld Farmer's ... auld Mare, Maggie." The latter poem is well known for its description of the bond between human and horse. Maggie and the speaker have known each other "some nine-an'-twenty year," and cooperated together in leisure and labor: "Thou was a noble fittie-lan' [horse near to plow], / As e'er in tug or tow was drawn! / Aft tee an' I, in aught hours' gaun, / On guid March-weather, / Hae turn'd sax rood [six rods] beside our han' / For days thegither" (19, 61-67). More than a mere tool of his farm's economy, Maggie is a named inhabitant, a member of the family that participates in both the labor that enables the community's economic life, but also the cultural rituals that comprise the its social structure. The poem's exegesis is the speaker's gift to Maggie of "The Accustomed Ripp of Corn to Hanzel in the New Year," and the reminiscence of Maggie's participation in his life's events, and his in hers, that the occasion sparks. On the speaker's wedding "day, ye pranc'd wi' muckle pride, / When ye bure hame my bonie Bride: / An' sweet an' gracefu' she did ride / Wi' maiden air! / KYLE-STEWART I could bragged wide, / For sic a pair" (31-6). Maggie here is more than a mere vehicle bearing the human plot of the speaker's wedding, but an essential character in that cultural ceremony itself; it is the "pair" of Maggie and bride that makes the speaker feel pride within his wider community of Kyle Stewart. Unlike in Burns pastoral sketch "Afton," whose speaker asserts possession over a conflated woman-and-nature, the Auld Farmer recalls the beginnings of a personal and rhetorically interactive relationship between himself, Maggie, and his wife, one which spans decades of mutual responsibility and care.

The anthropomorphism present in Burns' depiction of Maggie and other plants and animals creates a conception of environment not as passive landscape, but as a living ecosystem comprised of creatures with subjective, rhetorical agency. Ecocritics have criticized 
anthropomorphism as projecting a non-ecological, anthropocentric frame of reference upon the environment (Garrard 154-5). It may be objected, for example, that Maggie's "muckle pride" is unknowable to the Auld Farmer, and that his own feelings of joy lead him to perceive a "prance" in her gait that is not really there. Yet we must remember that the Auld Farmer is witnessing not just a random horse, but "his Auld Mare Maggie," a fellow-creature with whom he has lived, toild, and communicated for twenty-nine years. The act of ploughing, for instance, pits a literally tethered Auld Farmer and Maggie at a cooperative and mutually-understood task, performing separate, yet entwined functions, communicating both verbally and muscularly. Such cooperative interaction and communication with nonhuman beings is intrinsic to agricultural labor. Indeed, it might be said that a farmer is precisely as good at her job as the number and variety of surrounding actants she can perceive and effectively communicate with. As employed in Burns' georgic animal poetry, anthropomorphism effectively mixes nature and culture by elevating the perspectives of nonhumans through practice of empathy, or, in Smith's terms, "moral sentiment," which he argued was the ethical glue that binds inherently self-interested beings together into social units. Burns' willingness to project speech through the bodies of sheep, dogs, or horses, or even of a stalk of barley in "John Barleycorn," portrays the nonhuman environment as a living, cultural space, populated by rhetorical actants equally powerful and impactful as human beings. Critics of anthropomorphism ironically re-inscribe the pastoral split between nature and culture by assuming that the consciousness of humans is separate from what it perceives; thus in "Afton" the human narrator is unconcerned with comprehending the meaning of the water or birds' voices, merely with their impact on maintaining his human Mary's slumber. The anthropomorphism of Burns' georgic follows an ontology less of Descartes and Kant than of 
Spinoza and Goethe, who find "a perfect correspondence between the inner nature of man and the structure of external reality, between the soul and the world" (Heller 23).

In this sense, the georgic mode has the capacity to construct a sort of deep ecology. Drawn from Spinoza's pantheism, the guiding principle of deep ecology is that all living beings possess an inherent value and consciousness deserving of the same respect humans devote to each other. Nonhuman beings should thus not be regarded in terms of the instrumentality to human social survival, but as independent beings in their own right. The problem with deep ecology is, of course, that we all must eat, and to eat we must maim and kill. Burns addresses this contradiction in his most famous agricultural poem, "To a Mouse, On Turning up Her Nest with the Plough, November, 1785." The poem begins with anthropomorphized empathy for the mouse: "Wee sleeket, cowran, tim'rous beastie, / O what a panic's in thy breastie!" (1-2). Burns apologizes with an acknowledgement that the mouse is his "poor, earth-born companion, / An' fellow-mortal!" The farmer's assurance of "fellowship" has the effect of leveling the significance of mice and men, at once raising the mouse to an object worthy of Smithian sympathy and lowering the man to an animal also requiring basic necessities such as shelter from the cold. Burns' mouse "saw the fields laid bare an waste" (emphasis added), invoking the very term British humans applied to uncultivated, and thus ecologically lush, spaces, ironically now labeling the "improved" agricultural human landscape as useless to the mouse population. (25). This move reminds the reader that the farmer's very act of plowing is itself in service of obtaining the same basic requirements for survival that concern the mouse: just as the latter's "wee bit heap o leaves an stibble, / Has cost thee monie a wary nibble," so does the farmer's production of food ensure his own family's shelter, in the exchange for rent or mortgage (31-32). Crucially, though the farmer sympathizes with the victims of his actions, he cannot alter them: to 
eat, he must displace the mouse. Agriculture is a basic reality to all human life, and neither Burns' poetry nor deep ecology nor ecocritical theory can present any more ecologically "just" alternative.

The pastoral perspective turns away from this problem, eliding the necessarily violent extraction of energy from the environment by constructing a fantasy in which concerns of human economy are separated from a flattened, exploitable "natural" landscape. Yet the georgic faces it head on, diving into detailed realities of rural labor to describe, and prescribe, ways in which extraction can be performed more ethically. Though engagement with agricultural technique can be found more readily in Burns' correspondence than his poetry, his poems do often venture into such territory. One example occurs early in his Kilmanaroc volume, titled "The Death and Dying Words of Poor Mailie, the Author's Only Pet Yowe," which satirizes the then-popular genre of "Last Words" poetry (Leask 146). The poem is spoken in Mailie's voice, chastising Burns for poor farming techniques that left her "warsl'd in the ditch" (4). Mailie tells Burns

if e'er again he keep

As muckle gear as buy a sheep,

O, bid him never tye them mair,

Wi' wicked strings o' hemp or hair!

But ca them out to park or hill,

An' let them wander at their will:

So, may his flock increase an' grow

To scores o' lambs, an' packs of woo'! (17-24)

In this stanza Mailie implores Burns to improve. Mailie ends up in the ditch because he tethers her to a post, which was a common method of raising sheep kept for household meat, milk and 
wool. But this practice is Mailie's downfall when she gets tangled in the rope and collapses lame in a ditch. Following the didactic tradition of the georgic mode, Mailie instructs Burns to stop tethering and instead enclose tracts of nearby pasture in which his flock can "wander at their will." This practice will result in healthier sheep, due to decreased exposure to pathogens and parasites, and ultimately, as Mailie recognizes, lead to higher production. Leask notes that in an early version of the poem, Mailie is revealed to be "born of 'famous breed' of Fairlie lambs, produced by the stockbreeder and agricultural improver Alexander Fairlie of Fairlie, factor of the Earl of Eglinton, and she had clearly cost Burns a hefty sum of money" (149). Thus Mailie instructs her male lamb to "ne'er forgather up, / Wi' onie blastet, moorlan toop; / But ay keep mind to moop an' mell, / Wi' sheep o' credit like thysel!" (53-6). Mailie is aware of her dual status as both Burns' "pet" hand-reared lamb, and financial investment; she is a sheep of "credit" in both senses. By putting this lesson in the anthropomorphized voice of Mailie herself, Burns assures that his agricultural prescription will be designed with both human and sheep in mind. But whether Burns sings in the mode of "Afton's" leisurely pastoral or "Mailie's" laborious georgic, his tone is less critical than celebratory. Unlike Clare, Burns was no enemy of improvement and enclosure, and he did not intend his use of georgic to serve some cause of agrarian reform protesting economic exploitation of the rural laboring class, much less a political program we might today label "environmentalist." Beyond his stated admiration of Smith's commercially-enthusiastic Wealth of Nations, Burns also comments approvingly on various methods of the "new husbandry" in his travel journals, and indeed sought to implement them with excitement on his own farms. The variety and playfulness of Burns' poetry has frustrated readers seeking endorsements of particular political views, leading those scholars that give it a 
try to convincingly argue Burns as variously a Whig, Tory, radical, and/or Jacobite. 9 But the ambivalence present within Burns' oeuvre that can support such varying interpretations lends more weight to his wide reputation as an "apolitical poet of conviviality, carnality, and the unchanging rhythms of the natural world" (Kidd 61). Burns shows an appreciation for leisure of a depth measured by his experience of real labor; indeed, one cannot know one without the other, and it is this dichotomy that forms the relationship between pastoral and georgic.

Yet close reading of Burns' agricultural poetry does reveal a certain wariness with the cultural effects of the urbanization that improvement fosters. Burns' apology to the mouse, after all, is specifically that "Man's dominion / Has broken Nature's social union / An' justifies that ill opinion, / Which makes thee startle" (7-10). Echoing Rousseau, Burns here claims the existence of some point at which human "improvement" has transgressed on a pre-lapsarian state of "social union" within ecological economy.10 And "To a Mouse" specifically references the date of 1785 in its title, which sits directly amid Ayrshire's shift from a primarily agrarian to urban-industrial society. That modernization separates the population from the extractive labor that sustains it, and from direct experience of the georgic discursive economy. As Smith demonstrates, "the understandings of the greater part of men are necessarily formed by their ordinary employments"; it is the sustained experience of agricultural labor that forms the georgic into a mode of discourse and life which conceives nature as a cultural space. As Low puts it, the georgic (and I'd add pastoral too) is "more than simply a literary genre or mode, for it entails a

9 See Colin Kidd for examination of Burns politlical views within the "difficult and cross grained ... party politics of his times" (63).

10 Burns' work elsewhere demonstrates specific familarity with Rousseau, but scholars have been unable to determine exactly which texts Burns read, or when. See Tholoniat for intersections between the two. 
way of living and seeing as well as of writing" (12). What seems to concern Burns at the modern turn is his neighbors' increasing alienation from the sympathy with nonhuman beings that frequent and direct georgic labor fosters. The ploughman of Burns' "Mouse" is forced to confront the ecological consequences of his social existence, and responds with Smithian "moral sentiment." Removing agricultural activity from the daily life of human actors discourages that sympathy for the nonhuman, and encourages instead a pastoral idea of a natural reservoir separated from human society, which more readily permits capitalistic environmental exploitation. Burns' ploughman foresees such trouble in his closing warning that "the best laid schemes o' Mice an' Men"—-whether they be for a new nest or an improved field—"Gang aft agley, / An' lea'e us nought but grief an' pain, / For promis'd joy!" (39-42).

"The Brigs of Ayr" expands on this warning in one of Burns' few direct descriptions of urban landscapes. Burns wrote "Brigs" after the publication of his Kilmanaroc volume to commemorate the construction of a second bridge over the river Ayr able to accept the increased commercial traffic required by the town's modernization. A desire to see the poem in print was one of Burns' chief reasons for publishing an expanded Edinburgh edition of poetry in 1787, which counted Adam Smith himself among its many subscribers (Letters 53). Burns' poem participates in the Scottish flyting tradition by dramatizing a disagreement between Sprites of the "New" and "Auld" bridges across the Ayr, which represent the perspectives of medievalism and modernity. Burns writes that the "Auld Brig appear'd of ancient Pictish race, / The vera wrinkles Gothic in his face," whereas "New Brig was buskit in a braw, new clat, / That he, at Lon'on, frae any Adams got," marking the latter a clear stand in for the urban-imported commercial changes arriving in Ayrshire (77-82). 
The speaker who witnesses and relays this flyte between modern and medieval is marked early as a clearly georgic figure. "The simple Bard, rough at the rustic plow," as the poem begins, is on a nocturnal early-winter journey from his country home to the growing city of Ayr (1). He adds a hardened realism by noting himself to be "by early Poverty to hardship steel'd, / And train'd to arms in stern Misfortune's field," and places his narrative within the actual contemporaneous setting of the "ancient brugh of Ayr," taking pains to observe several local landmarks and establishments $(9-10,49)$. His concerns are both ecological and economic, musing on the agricultural activity associated with the coming winter, as "the stacks get on their winter-hap, / And thack and rape secure the toil-won crap," while the human hunting of birds "'doom'd by Man, that tyrant o'er the weak" render "Sires, mothers, children, in one carnage lie" (25-6, 32-37). Though the speaker's "warm, poetic heart but inly bleeds, / And execrates man's savage, ruthless deeds" he in the next lines compares the human hunt to the cyclical dying of vegetation and insects, placing the actions and fate of man within the inevitable recurrent destruction and regeneration of nature (38-39). The speaker even invokes an animist ethos, commenting "That Bards are second-sighted is nae joke, / And ken the lingo of the sp'ritual folk" (73-4). It is the farmer-Bard's georgic habit of regarding nonhuman objects as cultural actors that enables the reader to perceive the rhetorical argument between the real-life Brigs.

The flyte itself contends the ancient dialectic between traditional and modern, which Burns overlays with tones of georgic and pastoral. Burns allows both Brigs witty attacks and rejoinders, and though the New Brig gets the last word, it's unclear by the flyte's end which has prevailed. Yet the poem concludes with an odd turn, when, as witnessed again by our georgic spectator, "A fairy train appear'd in order bright" (195). Arriving to the tune of "old Scotia's melting airs," we receive an array of rural Sprites, led by the "venerable Chief" of "The Genius 
of the Stream," followed by "Sweet Female Beauty hand in hand with Spring; / Then, crown'd with flow'ry hay, came Rural Joy, /And Summer, with his fervid-beaming eye" (205-220) The parade of fairies arrives as visitors to the Brigs' urban argument from the rural realm, bringing a pastoral sense of "Rural Joy." Yet even Leask finds here hints too of "georgic tones" celebrating the rural work that enabled the Brigs' argument in the first place (208). The poem ends:

Last, white rob'd Peace, crow'd with a hazle wreath,

To rustic Agriculture did bequeath

The broken, iron instruments of Death,

At sight of whom our Sprites forgat their kindling wrath. (231-4)

Leask interprets the poem's close as "a fitting paen to the nobler ... spirit of agricultural improvement triumphing" over the Brigs' tiresome quarrel (209). And I think he is correct; as we've seen, Burns was personally invested in improvement, and indeed dedicated this very poem to the construction of the modern, "New Brig." Yet it is important to note that Burns' answer to the Brig's flyte arrives from the country, bearing both "Rural Joy" and rural concerns to the urban quarrel between Auld and New. At the poem's close, it is not to improved, but to "rustic" agriculture that Peace bequeaths "The broken, iron instruments of Death."

Burns here makes a critique of the urban, pastoral paradigm similar to Latour's claim that "we have never been modern." In their flyte, the Auld Brig states that the New Brig, born of commerce rather than agriculture, is unfamiliar with the continual powerful crush of the nonhuman, of "blustering winds an' spotting throwes, / In mony a torrent down the snaw-broo rowes; / While crashing ice, borne on the roaring speat, / Sweeps dams, an' mills, an' brigs, a' to the gate" (119-122). Built in pre-modern medieval times, by inhabitants of Ayr unable to use commercial work to escape the daily economic interaction with nonhuman nature, the Auld Brig 
can and has withstood this onslaught, taunting that "I'll be a Brig when ye're a shapeless cairn!" (110). Commercial society is built upon the assumption that the whims of nonhuman nature can be conquered by technological advancements, whether in the agricultural or architectural realm. Yet, as Latour argues and the georgic perspective reveals, nature is not something which can be surpassed, nor cordoned off from a purely "human" society by a pastoral ecological perspective. So long as humans are to remain alive, we must practice agriculture, and it is practice specifically of the "rustic" sort to which the fairies bequeath "The broken, iron instruments of death." This is because it is human-powered methods of energy extraction, rather than the oilfueled industrial sort, that inculcates ontological awareness of the enmeshment of human social structures with the environment. Ultimately Burns endorses agricultural improvement and modernization by celebrating the "new Brig" with his poem, yet with the caveat that georgic lessons of the intertwining of ecology and economy must be protected. The Brigs are ultimately silenced by a hybrid train of pastoral and georgic, which presents a synthesis between the dialectic of Auld and New, rural and urban. Modern commerce and the pastoral perspective it inspires should be celebrated, but not allowed to subsume the agricultural economy, which is why Burns' celebration of the New Brig features centrally, and elevates equally, the perspective of the Auld.

IV.

According to most literary critics of pastoral discourse, with the nineteenth-century's increasingly widespread urbanization came a waning of the georgic mode. Anne Wallace writes that "traditional literary historical accounts of pastoral and georgic at the end of the eighteenthcentury argue that 'georgic' ceases to be a functional critical term" (115). Wallace summarizes the critical consensus that georgic disappears partly due to the British imitation of the classical 
georgic becoming unfashionable, and partly because Romantic pastoral "assimilated" georgic into a "hard pastoral," dealing with labor as an unfortunate side-effect of being rural and poor, rather than as an issue of thematic concern in its own right (115). To some extent, these critics are right. Burns' work shows how tightly economic labor, environmental landscape, and environmental consciousness are intertwined; as one component is modernized, so are the others. The eighteenth-century concluded with the French and American revolutions, and with them, the formal inscription of principles of modernization within the social contract; the entwined practices of agricultural improvement, industrialization, and urbanization ceased to be experiments, and became ideology. Pastoralism, as the urban conception of nature, grew in tandem with the spread of urbanization across the landscape.

Yet, despite what many recent critics of pastoral assume, neither agricultural labor nor georgic discourse disappeared overnight, nor without a fight. Though by 1800 the transition from human to oil power in agriculture was assured, it was not complete. Extractive work remained a common and important category of labor throughout the nineteenth- and twentieth-centuries, and with it comes georgic discourse, no matter how suppressed or disguised. As Wallace and other scholars of georgic such as Low, Feingold, and Heinzelman argue, critical use of the term "pastoral" casts too wide a net, "deceptively cloak[ing] the ... ongoing use of georgic" through the Romantic period and beyond (Wallace 511).

The following chapters will turn to the United States - the arena in which Enlightenment Britain carried out its agricultural and modernizing experiments, and which as a result has become the world's most flamboyant and extravagant expresser of the modern idea — to trace the response of georgic discourse to urbanization across the rest of the modern period, and up to the present. For though now the food lining American grocery shelves is nearly entirely produced by 
the labors of dehumanized immigrants and oil, and the shoppers lining the aisles possess an overwhelmingly pastoral conception of that food's origins, there still exist a plethora of individuals and communities around the world practicing georgic discourse and economy. And it may be that the georgic mode is due for a popular resurrection. Though Burns' New Brig gets the last word, history rendered prophetic the Auld Brig's claim that "I'll be a Brig when you're a shapeless cairn!" when the New Brig collapsed in 1877 after destructive floods. The Auld Brig, however, was restored in 1910 — with the financial assistance of Burns' clubs around the worldand its stones still stand, bearing commerce, to this day. 


\section{Crèvecoeur and the Roots of American Agrarianism}

American colonization fueled European modernization materially and conceptually. America's shores presented to the European mind an imaginary arena of pure, pastoralized nature untethered to history and experience - a "state of nature," or "tabula rasa," in which Modern political and economic theories could be applied and tested. Though all guided by this Modern zeitgeist, colonial settlement patterns were diverse, and dictated by climate, resource distribution, and the cultural and geopolitical situation of the specific colonial venture. These factors convened in British North America, especially above the Mason-Dixon, to produce a unique ecological-economic system and accompanying ideological paradigm that came to be known as "agrarianism." Conceptualized most famously and influentially by Thomas Jefferson, American agrarianism applies Enlightenment ideas to the British colonial experience to posit that the act of agriculture inspires the ideal traits of a virtuous citizen, and that therefore a dominant population of freeholder farmers secures socio-ecological peace and prosperity. As the neo-Jeffersonian John Crowe Ransom writes in the 1930s, "The theory of agrarianism is that the culture of the soil is the best and most sensitive of vocations, and that therefore it should have the economic preference and enlist the maximum number of workers" (xlvii). Agrarianism has been politically and economically influential throughout American history, and has enjoyed a particular resurgence in the last fifty years as a mode of environmentalist practice. It is also the wing of environmentalism, and indeed of all 21 st-century political thought, that most foregrounds the georgic: thus any recovery of georgic discourse will flow through its inspirational yet problematic history, which can offer guidance for today's agrarians. 
This chapter will examine the roots of American agrarianism as depicted in J. Hector St.

John de Crèvecoeur's 1782 Letters from an American Farmer. Born in 1735 to a family of petitenoblesse in Normandy, Crèvecoeur migrated to Quebec in 1755 and served as an officer and cartographer in the French army during the Seven Years War, where he honed the eye for landscape function his writing so adeptly demonstrates. After being dismissed from the army for reasons lost to history, Crèvecoeur started a family and bought a 120 acre farm he named Pine Hill near today's Chester, New York. His Letters present a fictionalized version of his American experience, in which Crèvecoeur uses the georgic mode and an ironic narrator, "farmer James," to articulate an agrarian vision of the mid-Atlantic in which peace and stability are secured by a community of freeholding farm families who, by working to raise their own subsistence, are able to maintain independence from the excesses and injustices of the urban-industrial marketplace. Crèvecoeur is most famous for this vision of American agrarianism, which he presents in the early Letter III. But as the Letters progress, Crèvecoeur shifts from celebration to critique as he compares agrarianism to the ecological-economic systems of Nantucket, South Carolina, Europe, and Indian communities. At the violent outbreak of the American revolution, James becomes disillusioned, recognizing that the "independence" his agrarianism values is impossible, and that it will inevitably be out-competed, both materially by urban-industrial ecological-economies, and ideologically by the pastoralism that underwrites them. Yet while Crèvecoeur himself flees back to France, his narrator James emigrates to an Indian community, where he hopes to continue his agrarian life as "a simple cultivator of the earth" (7). Critics are divided on the significance of this "darkening" of the Letters, but I will argue that James' decision represents a legitimate and revolutionary, if incomplete, attempt to address the internal tensions and weaknesses of American agrarianism (Holbo 52). Ultimately, Crèvecoeur 's last letter locates a more just and 
resilient form of georgic American agrarianism in anti-market Indian ecological-economies oriented toward subsistence rather than profit. While Crèvecoeur himself turned away from this recognition, the choice of today's agrarians, and environmentalists, remains open.

I.

Despite the immense popularity of the pastoral mode in early modern Britain, a pastoral literature and consciousness was slow to develop in the Americas. This is because pastoral is typically written from a leisured, urban perspective, and early American settlements had very little of either. America's operation as a resource colony did not require the development of extensive urban spaces; the centers of finance, government, manufacturing, and trade that facilitated colonial activity remained in the burgeoning European cities of London, Paris, and Burns' Edinburgh.11 The early American experience of nature thus included no contemplative repose in manicured gardens or pastoral fields, but instead the intense manual work of wresting first a living, and then commodity surplus, out of an unfamiliar landscape filled with disease and danger. Puritan New England's utopian aims entailed town-based settlements of unusual population density and literary output that did include some inklings of pastoral, yet they were more likely to frame their environmental imaginings in Biblical rather than classical terms, seeing a "land of Canaan" rather than a Virgilian "Arcadia." In Buell's words, the generic "old world frames of reference - the Exodus narrative, pastoral convention, a basketful of English place-names - became defenses against the heart of darkness" (70). Though upper-class writers like Anne Bradstreet and Thomas Morton utilized pastoral conventions in the seventeenthcentury, it was not until the nineteenth that the vibrant literary tradition of American pastoral

11 See the introduction to Chapter 4 for an account of urban development in America. 
fully emerged, when rural communities were challenged by the incursion of the industrialtechnological "machine in the garden," in Leo Marx's famous phrasing.12

The roots of American pastoral lie in writers' more common use of georgic to describe early American landscapes. The earliest published British descriptions of America employ a mercantile version of georgic to portray a limitless expanse of natural resources ripe to be harvested and monetized. The writings of Thomas Harriot and Richard Hakluyt, for example, structure their description of the American landscape in terms of its potential production of "merchantable commodities" (Harriot 7). Tim Sweet writes in his study of early American Georgics that these authors used the georgic mode to "transform the existing economic vocabulary of 'commodity,' 'waste,' and 'vent' in relation to [the] newly recognized environmental context" of the New World, thus "theorizing economics anew in relation to environmental capacities" (Georgics 6-7). Georgic remained an important literary mode throughout the colonial period as a vehicle to develop extractive and agricultural approaches to suit the novel American ecosystem. Eighteenth-century writers like John Spurrier, John Filson, Benjamin Rush, John Lorain, and Thomas Jefferson penned agricultural travel journals and manuals that mixed pastoral constructions of picaresque valleys of rural farming communities with georgic concern for how those ecological-economies should operate. As Sweet writes, construction of early American "pastoral or Edenic imagery was thus supported by the georgic" ("Environment" 3).

Yet it is important to note that these writers all shared the goal of encouraging colonization, settlement, and "economic improvement." Thus, though their writings are clearly georgic in their attempts to "articulate a relationship between economy and environment that

12 See Dillman on further British uses of pastoral to "mask the harsher aspects of the West Indian experience" (138). See Sweet, "Environment," for a full treatment of Puritan expressions of pastoral and georgic. 
would foster the public good," the only sort of relationship they imagined was a staunchly capitalist one (Georgics 7). Early boosters like Hakluyt and Harriot minimized the risks of disease and violence and exaggerated the ease with which crops could be raised and resources could be commodified. And later georgic writers sought to promote expansion of the national economy by boosting new and larger settlements that could further increase overall resource extraction and export.

This is especially true for Thomas Jefferson, who has come to be known as the most prominent proponent of "agrarianism" among the founding fathers. Jefferson famously writes in Query XIX on "Manufactures" in his 1784 Notes on the State of Virginia that,

those who labor in the earth are the chosen people of God, if ever he had a chosen people, whose breasts he has made his peculiar deposit for substantial and genuine virtue.... [G]enerally speaking, the proportion which the aggregate of the other classes of citizens bears in any state to that of its husbandmen, is the proportion of its unsound to its healthy parts, and is a good-enough barometer whereby to measure its degree of corruption (170). Here Jefferson argues that the practice of farming instills civic virtue, and that it should therefore remain the basis for Virginia's - and indeed America's - economy. Yet it is important to consider what variety of agriculture Jefferson is recommending. He does not merely envision smallholder families producing for their own subsistence, but also vast farms raising commercial crops for industrial trade. For Jefferson does not call for a rural economy devoid of "manufactures," but merely for their production to "remain in Europe," buoyed by American exports of raw materials.13 Despite the extent to which Jefferson positions his agrarianism against the rise of

13 Jefferson's agrarian vision is as contradictory as Crèvecoeur's. Major and Smith write that it is "schizophrenic," a "mélange of elitist and democratic ideals: small family farmers relying principally on their own labor but not working too hard, producing enough for themselves but 
industrialism in Europe, his own vision is ironically industrial, using the rhetorical guise of national independence to legitimize the slave-dependent plantation agriculture of the American South. As Joyce Appleby writes, the disagreement between the Jeffersonians and the Hamiltonians was not, as it is often represented, "a conflict between the patrons of agrarian selfsufficiency and the proponents of modern commerce, but rather as a struggle between two different elaborations of capitalistic development in America" (836). Sweet's analysis shows that by the late eighteenth-century, the goal of georgic discourse "was to naturalize the market," attempting "to effect the disappearance of a significant oppositional ideology"—-that of subsistence agrarianism - " and to deny the legitimacy of communally-organized agricultural production, in order to promote capitalism in rural America ("Pastoralism" 76). Writers performed this task either by "excoriating" non-capitalist subsistence-oriented farming practices as unreasonable, impoverished, violent, and generally morally corrupt in their supposed incivility, or by "ignor[ing] altogether the existence of anti-market, backwoods farmers as a class" (Sweet 76).

Yet agricultures geared toward agrarian subsistence were present throughout colonial America, and indeed were the dominant ecological-economic mode in many areas. The largest population of subsistence farmers were of course American Indians. There exists a false yet common conception of Indians as hunter-gatherers passively reaping the abundance of an Edenic paradise, taking only what they needed from a "virgin" landscape that remained "untouched" before European contact. But as William Doolittle writes in his encyclopedic Cultivated Landscapes of Native North America, in 1491 "huge tracts of forests were cleared and farmed,

also for the market, actively engaged in commerce but not pursuing excessive wealth, and spending their spare time reading Home and keeping informed about (but not too involved in) national politics" $(22,18)$. 
rivers were re-routed to irrigate desert lands that nature never intended for the raising of crops, mountain slopes were terraced and planted, and wetlands were drained for cultivation" (4). These agricultural practices were culturally underwritten by a nonmodern, animist ontology that perceived a lively nonhuman environment comprised of active, conscious beings capable rhetorical interaction and deserving of respect. White invaders, on the other hand, brought from Europe the emerging pastoral conception of both land and its produce as "natural" nonhuman objects ontologically separate from humanity, and thus free to be owned and then commodified for financial gain. Instead of this capitalist ecological-economy, Indians oriented production toward subsistence, and bartered goods valued for their potential use rather than financial exchange.

But forms of subsistence agrarianism were also quite common in white colonial communities. Indeed, farms guided purely by capitalist economic logic were quite rare, since America's remoteness from manufacturing areas left colonists to produce much of their food, clothing, and shelter in the non-market domestic sphere, or to obtain them in local networks for sale or barter of goods and/or labor. Capitalist agriculture had its strongest foothold in the plantations of the South, where systems of indentured servitude and slavery took advantage of long growing seasons to industrially produce monocultural cash crops of tobacco, sugar, and cotton. But in the north-east, mid-Atlantic, and the hills of Appalachia, farms were to varying degrees aimed less toward profit and more toward community and self-provisioning. Richard Bushman finds in his analysis of farmers' journals and accounting books that eighteenth-century American farms simultaneously "operated in two economies, the self-provisioning economy of the household and the exchange economy where they bartered and sold" (11). Though the home economy was nested in the broader capitalist exchange economy, and the production methods of 
improvement were similar for both, "the two economies functioned on different principles....

Outside the household, buying and selling prevailed; everything was assigned a price. Within the household, there was no buying and selling, no setting of prices, no exchanges, no market" (11). Before industrialization began in earnest in the early nineteenth-century, "the core domestic farm economy, by far the largest single component of the North American economy, constituted a precapitalist, nonmarket family economy enclosed within the market economy beyond the household" (11).14 The heart of American agrarianism lies in this "middle landscape," as Marx calls it, caught then and today in tension between marketless self-subsistence and the surrounding capitalist marketplace (32). And at the dawn of the new United States, it was expressed with most nuance and thoughtfulness by Crèvecoeur.

II.

The complexity of American agrarianism is reflected in Crèvecoeur's life and Letters, which possess perhaps the most obscure origin and generic ambiguity of any text in the major American canon.15 Though the Letters begin as a seemingly straight-forward semiautobiographical epistolary account of life in America, the abrupt shift of setting to Nantucket and Charleston raise questions about James' credentials as an "ordinary" American farmer, who would likely to be unable to afford such excursions. And late in Letters readers are treated, without explanation, to a letter by a Russian visitor to Philadelphia, and a conclusion that

14 See Alexander Chayanov's 1925 Peasant Farm Organization for an economic analysis of subsistence agrarian economies nested within the socialist state of early Soviet Russia. 15 See Myers for an assessment of Crèvecoeur 's "penchant for secrecy; his suppression, obfuscation, or deliberate misrepresentation of certain events in his life; his insecurity, indeed at times, his paranoia - qualities that, far from being irrelevant, a judgment that has led to their becoming marginalized or ignored by many commentators, shrouded his life with mystery and definitively shaped all he did, and also invited deep suspicion of Crèvecoeur's political allegiance from individuals demanding far simpler, less complex explanations of human behavior" (358). 
deviates from Crèvecoeur's biography. Consideration of Crèvecoeur's full work, including other sketches published in his French editions and posthumously, reveal a sophisticated writer assuming the points of view of a variety of characters, from backwoods bankers to the sons of Jamaican planters. This complexity has sustained a plethora of diverse scholarly interpretation, especially surrounding the purpose and effect of James as narrator.16 Critics largely disagree on the number of narrators in the text, their relation to each other and to Crèvecoeur, and especially on the stance regarding American agrarianism that the Letters project. Are the Letters a paean to the agrarian ideal? And is this celebration naive? George Washington, for instance, said that "perhaps the picture he gives, though founded in fact, is in some instances embellished with rather too flattering circumstances" (358). Or does Crèvecoeur employ James as an ironic narrator to indict his earlier views, and if so, upon what counts? 17

The remainder of this chapter will attempt to answer these questions by reading Crèvecoeur as an economic writer. That his work has not been considered as such is indicative of the pastoral nature of literary scholarship, which tends to gloss over material economic content in favor of adjudicating the subject position of human narrators, as Crèvecoeur scholars have

16 Machor summarizes in 1982 that "within the past fifteen years, students of Crèvecoeur increasingly have pointed out the ironic qualifications surrounding James and have asserted, quite correctly, that he is only a persona. While a few have gone so far as to call James 'an incorrigible idealist and moral coward' and Crèvecoeur's 'straw man,' most critics now agree that Crèvecoeur uses the farmer's plight to undermine Enlightenment assumptions and assert the failure of the American ideal" (75).

17 The difficulty of these questions is compounded by the obscurity surrounding the Letters' editorial process. Moore writes that "there is no definitive textual or biographical evidence that Crèvecoeur had planned" the Letters' "overall effect" during composition (xv). Yet we can surmise some endorsement of their narrative arc because Crèvecoeur retained it through multiple revisions (Moore xxxiii). Rapping also notes that his later Journey into Northern Pennsylvania and the State of New York follows a similar structure, in which "the cumulative effect of the narrative is to convince the reader, if not the narrator [himself,] that the model" he had earlier espoused "represents a false view of the world which will not stand the test of experience" (708). 
largely done.18 Yet Crèvecoeur's dominant mode of analysis is ecological-economic, concerned primarily with comprehending and describing the ways various human populations interact with their environment to generate a living. Or, in his own words, "to examine how the world is gradually settled, how the howling swamp is converted into a pleasing meadow, the rough ridge into a fine field" (Letters 63). Crèvecoeur is a systems-thinker, and approaches each new landscape he surveys with an eye towards the networks of plants, animals, climate, and commerce that structure the life that comprises them. In Nantucket, for instance, Crèvecoeur explains how these spheres are woven together thus:

There are but few gardens and arable fields in the neighborhood of the town, for nothing can be more sterile and steady than this part of the island; they have however the unwearied perseverance, by bringing a variety of manure, and by cow-penning, enriched several spots where they raise Indian corn, potatoes, pomions, turnips \&tc. On the highest part of this sandy eminence, four windmills grind grain they raise to export; and contiguous to them their rope-walk is to be seen, where a full half of their cordage is manufactured. (Letters 91)

Crèvecoeur, like Smith and Burns, recognizes that human culture is inculcated by economic and ecological situation. To understand the one we must grasp the other, and Crèvecoeur sees this connection lacking in contemporary Enlightenment writing and thought: "Authors will convey to you a geographical knowledge of this country," he writes, "yet they do not sufficiently disclose the genius of the people, their various customs, their modes of agriculture, the innumerable resources which the industrious have of raising themselves to a comfortable and easy situation.

18 One exception is Panela Regis, who insists on reading Crèvecoeur as a science writer. I would add to her analysis that he performs social science and natural science simultaneously, before they were separated disciplinarily. 
Few of these writers have ... carefully examined the nature and principles of our association" (Letters 83-4). Crèvecoeur's writing is georgic in that it seeks to "examine" the "principles of our association" with other humans, and ecological in its expansion of that examination to nonhuman beings. Crèvecoeur employs the same analytical lens to Nantucket settlements as he does to families of birds and bees, to the social connection of snakes and hummingbirds, and the operations of "ant-hill towns" (Sketches 51).

Crèvecoeur performs his ecological-economic methodology in the georgic mode. 19 Though mere attention to the connection of economy and ecology is the bedrock condition of georgic, Crèvecoeur also incorporates the mode's didacticism, attention to agricultural process, celebration of rural felicity common also to the pastoral, and specific celebration of the virtues of extractive labor. These features abound across Crèvecoeur's oeuvre, but one evocative representative example is his descriptions of ploughing. Crèvecoeur, like Burns, finds this task "most agreeable," because "my labor flows from instinct as well as that of my horses; there is no kind of difference between us in our different shares of that operation" (Letters 20). Crèvecoeur's horses are not tools or possessions, but co-workers, raising grain for Crèvecoeur as well as themselves. Eight pages later, Crèvecoeur expounds,

Often, when I plough my low ground, I place my little boy on a chair which screws to the beam of the plow. ... the odiferous furrow exhilarates his spirits, and seems to do the child a great deal of good, for he looks more blooming since I have adopted that practice. Can more pleasure, more dignity, be added to that primary occupation? The father, thus ploughing with his child, and to feed his family, is inferior only to the emperor of China ploughing as an example to feed his kingdom. (Letters 27-8)

19 See Lamore for a thorough treatment of Crèvecoeur's debt to Virgil in style and substance. 
Crèvecoeur here presents a pastoral description of rural happiness, yet expands into georgic by celebrating the labor that materially drives the scene. Like Virgil, Crèvecoeur stresses the civic virtue of this extractive work, which brings both "dignity" to his national community, and "blooming" "good" to future generations. Crèvecoeur continues, "In the evening, when I return home through my low grounds, I am astonished at the myriad insects which I perceive dancing in the beams of the setting sun. I was before scarcely acquainted with their existence ... they are carefully improving this short evening space" (Letters 28). Before becoming a farmer, Crèvecoeur was "scarcely acquainted" with these insects and indeed all manner of other living things, yet his new economic entanglement with them requires their apprehension, and then inspires their appreciation. It is specifically the "odiferous furrow" that "exhilarates" his son's "spirits"; the smell of freshly turned earth—derived from the billions of organisms teeming through each teaspoon of soil-is something which cannot be described with words, but can only be experienced and alluded to: "we enjoy in our woods a substantial happiness which the wonders of art cannot communicate" (Letters 150). And, as in Burns' georgic, it is the act of agriculture that inculcates a connected civic virtue and environmental appreciation: "the simple cultivation of the earth purifies" (Letters 45). One can imagine Jefferson or other early American georgic writers penning such sentiments, but Crèvecoeur adds an ecological perspective, in which not only humans, but insects too "improve" the landscape, thus "mak[ing] the face of nature smile" (Letters 28, 137).

Because Crèvecoeur recognizes the act of farming is essential to achieving the georgic felicity of his ecological-economic consciousness, the American farmer becomes the hero of his narrative, and he recommends a political philosophy that allows for the maximum number of people to farm. Crèvecoeur expresses distrust and disdain for urban professions throughout his 
work, from bankers to land speculators to, especially, lawyers, who "are plants that will grow in any soil that is cultivated by the hands of others; and, when once they have taken root, they will extinguish every other vegetable that grows around them" (Letters 135). The labors that Crèvecoeur celebrates are those that extract energy from the immediate environment, from farming and gardening to whale-hunting and women's domestic work, or what he calls "internal economy" (Letters 209). Extracting the energy one consumes oneself underlies the prime virtue of Crèvecoeur's vision of American agrarianism: political and economic "independence," or the "freedom" to create one's own economic network, without interference from an intrusive political elite: "I have never possessed, or wish to possess anything more than what could be earned or produced by the united industry of my family" (Letters 200).

Crèvecoeur is clear that this prized independence is founded on the establishment and protection of the absolute right to private property. He writes,

What should we American farmers be without the distinct possession of that soil? ... This formerly rude soil has been converted by my father into a pleasant farm, and in return it has established all our rights; on it is founded our rank, our freedom, our power as citizens, our importance as inhabitants of such a district. These images I must confess I always behold with pleasure, and extend them as far as my imagination can reach: for this is what may be called the true and the only philosophy of an American farmer. (Letters 27).

Unlike the Feudal commons of Burns' pre-modern agrarian Ayrshire, property rights are politically essential for Crèvecoeur's American agrarianism. Yet Crèvecoeur also conceptualizes and values them in ways that differ from the capitalist desire to accumulate and protect wealth. Crèvecoeur explicitly defines property in non-capitalist terms: "by riches I do not mean gold and 
silver, we have but little of those metals: I mean a better sort of wealth; cleared lands, cattle, good houses, good clothes, and an increase of people to enjoy them" (Letters 55). He thus values his land not for its exchange value but for the subsistence it can provide him: "it clothes us [providing] our best meat, our richest drink, the very honey of our bees" (Letters 27). Through ecological energy exchange, the land and the family share one life; they possess each other. In Crèvecoeur's vision, local cooperative community economies take the place of a capitalist marketplace. James' farm, and the others in his area, act as equal social units in a community devoid of other significant institutions (religious organizations being the exception). And Crèvecoeur is happy with this arrangement, for his distrust of urban professions extends to urban spaces and institutions as well, which he describes as "but the confined theatre of cupidity; they exhibit nothing but the action and reaction of a variety of passions which, being confined within narrow channels, impel one another with the greatest vigors" (Sketches 53). Whereas the diverse ecological actors of a family farm temper and humiliate human "passions," the "narrow channels" of urban spaces delude residents by amplifying their significance. Myra Jehlen writes of Crèvecoeur's "general rejection of the commercial nexus. For him the marketplace did not make for a better product, but for the ferocities of the jungle" (217). In lieu of market relationships, Crèvecoeur celebrates informal cooperative community economies. The climax to Crèvecoeur's history of the successful immigrant Andrew the Hebridean is a "neighborhood ... . frolic" in which "about 40 people repair" to Andrew's land to help him clear a field and build his house (Letters 80). Crèvecoeur implies that such cooperative events are typical, and even goes so far as to say that "from the first day he had landed, Andrew marched towards this important event: this memorable day made the sun shine on that land on which he was to sow" (Letters 81). For Crèvecoeur, Andrew's true success is not marked by the accumulation of wealth or even 
the acquisition of land, but by participating in and benefiting from communal agrarian projects and production. In a sketch, Crèvecoeur's narrator describes at more length the substance of these "frolics," and tells his correspondent that "I could have wished when you were with me that I could have carried you to such an assembly. There you would have seen better what the American farmers are than by seeing them singly in their homes" (Sketches 97). For Crèvecoeur, this type of helpful community interaction is the true essence of American agrarianism. Unlike America's early English boosters, Crèvecoeur's georgic prizes informal community economy aimed at "subsistence," rather than capitalist commodification and profit (Sketches 95).

III.

Though best known for this articulation and celebration of American agrarianism, Crèvecoeur's Letters also present a "searching criticism of it" (Philbrick 88). Close reading of Letters and Sketches reveal the seeds of internal tensions within the ideology and practice of American agrarianism that would lead to the decline of its felicitous "middle landscape" throughout the nineteenth-century. Crèvecoeur's agrarianism is vulnerable first because the independence it values rests on the establishment and protection of property rights, which are themselves entirely dependent on the fragile stability of political government. Jehlen writes that this "problem of reconciling individual independence with mutuality was not Crèvecoeur's alone, [but] occupied his entire century, and for that matter, the next; we are still not clear what the concept of community means in a society of individualists" (207). James himself reconciles the paradox in his appreciation for British governmental "law at a distance"; too remote to meddle in the freedom of individual freeholders, but with power absolute and "ancient" enough to protect the property rights that guarantee that freedom (Letters 106, 192). Jehlen appropriately terms this political ideology a "monarcho-anarchism": Crèvecoeur's "definition of self-determination was ... 
more radical or more absolute that that which is commonly implied by democracy, because he could see in the accommodations of majority rule no advantages but only a loss of freedom for each individual" (221). This is why James remains a loyalist during the revolution, and ultimately flees the emerging U.S. government. He recognizes that the loss of British control would transfer power to American elites - the only people able to engage in the new democracy — and permit them to create governmental policies favorable to their financial and commercial interests. Centres of urban finance would no longer remain in Europe, and Crèvecoeur's "hated" cities would emerge in America, led by hordes of his hated lawyers, and the "innocent" class of farmers would become "victims of the few" (Sketches 53, Letters 191). Crèvecoeur provides a preview of the new United States in James' visit to Charleston, South Carolina, where an unchecked reverence for property rights permits an opulent accumulation of wealth at the expense of catastrophic, yet displaced and "unseen" social violence (Letters 153). James is taken aback by the "horrors of slavery, the hardship of incessant toils", and assures his correspondent that, though "we have slaves likewise in our northern provinces, ... they enjoy as much liberty as their masters, ... and are, truly speaking, a part of our families" (Letters 156). Even if we forgive this obviously false assertion, the relative lack of slavery north of the Mason-Dixon was not due to any moral superiority, but climate: the short growing season rendered it economically unfeasible to keep large populations of slaves fed and clothed yet idle during long winter months (Bushman 54). Instead, James and his neighbors were dependent on poor wage laborers and the unpaid labor of women, children, and slaves, who were never permitted to realize the benefits of property ownership themselves. Sweet shows that unlanded tenant farmers were also significantly more present and exploited than James' bootstraps anecdote of the successful Andrew the Hebridean suggests ("Pastoralism" 66). Ultimately, James 
is not as "independent" as he thinks he is: as Sweet writes, the possession of land "for one entails leisure, for the other, labor" ("Pastoralism" 64).20

Crèvecoeur's agrarianism tries to head off this potential for exploitation by keeping a distance from the market, yet his narrators find its influence to be inescapable. As Jehlen writes, "Crèvecoeur's agrarianism may have been based on the view that only farming could produce wealth without exploitation. ... a good man could become wealthy without engaging in imperialism or even commerce: without having to deprive his equals of the substance he acquires" (216). This is one reason self-sufficiency is so important to Crèvecoeur's speakers. In the Sketch "Thoughts of an American Farmer on Various Rural Subjects," the narrator first asserts proudly that "the philosopher's stone of an American farmer is to do everything within his own family to trouble his neighbors by borrowing as little as possible; and to abstain from buying European commodities." (Sketches 104). After relating with much pride "our different home manufactures, "from preserved meat and vegetables to perfumes, home-brewed beer, and dyes "of so many colours" made from "the roots and barks of our woods," the narrator then makes a swift about-face stating explicitly that nonetheless, "to live, it is necessary to go to market"; "English goods ... present irresistible temptations. It is so much easier to buy than it is to spin. The allurements of fineries is so powerful with our young girls that they must be philosophers indeed to abstain from them" (Sketches 94, 124, 15-1). Independence may be the "only philosophy" of an American farmer, but the farmers themselves are incapable of its implementation (Letters 27).

20 Jeff Osbourne argues that Crèvecoeur is conscious of this problem: "by contradicting James' liberalist utopianism" in the later letters, "Crèvecoeur assays a scathing indictment of social histories grounded in ideal principles of Nature that ignore the violence of American social and economic structures" (530). 
External connections with the forces of commerce are inescapable for the American farmer because of the United States' initial founding as a colonial outpost of the international capitalist marketplace. The writers that rhetorically constructed early America, and the settlers that materially built it, did so according to a capitalist logic. The voyages were financed through corporations which expected the repayment of debt with the sale of commodities. In this sense, capitalism arrived in America before any Europeans did. William Cronon notes that when compared to the industrial agriculture of the nineteenth-century and the present, early American communities look relatively marketless and subsistence-oriented, but their need to pay taxes, repay loans, and their belief in agricultural improvement as the way to do so rendered them firmly "market societies, the seeds of whose capitalist future were already present" (76). And these seeds were sure to sprout and their vines to invade, since the logic of capitalism is totalitarian in its continual need for growth, the maximization of productivity requiring its tendrils to shape every ecological-economic interaction. By the revolution, capitalist economic relations were entrenched enough to permit no ecological-economic option that preserved a wariness of the market within any white community. James' beloved communal frolics were being quickly displaced by the market square.

A final, yet important, limitation of Crèvecoeur's agrarianism would have been unthinkable to early Americans perched on the precipice of a great wilderness: its ecological unsustainability. Market farms simply cannot exist without extensive energy inputs from outside of their boundaries. If energy leaves the farm in the form of commercial products bound for urban centers, fertility will decline. Though the vast expanse of healthy land allowed American farmers to elide this problem inherent to capitalist agriculture, farmers in Europe were facing

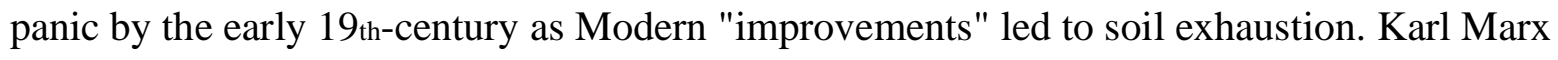


theorized this problem as an "irreparable rift" in the "metabolic interaction between man and earth": "Capitalist production collects the population together in great centres, and causes the urban population to achieve an ever-growing preponderance. This ... disturbs the metabolic interaction between man and the earth, i.e. it prevents the return to the soil of its constituent elements consumed by man in the form of food and clothing; hence it hinders the operation of the eternal natural condition for the lasting fertility of the soil" (637-38).21 Though the small farms of Crèvecoeur's mid-Atlantic were more diversified and sustainable than most in America today, they remained, in Cronon's terms, "ecologically self-destructive. They assumed the limitless availability of more land to exploit, and in the long run that was impossible" (169). Farmer James is not only unable to escape the tethers of the market economically and politically, but also ecologically and metabolically.

IV.

In Crèvecoeur's last Letter XII, "Distresses of a Frontier Man," James faces the annihilation of his family at the hands of Indian raiders allied with revolutionaries, leading him to question the foundations of his agrarian philosophy, especially with regard to its emphasis on "independence." For, as James writes,

what is man when no longer connected with society; or when he finds himself surrounded by a convulsed and half-dissolved one? He cannot live in solitude, he must belong to some community, bound by some ties, however imperfect. ... I had never before these calamitous times, formed any such ideas; I lived on, labored, and prospered, without

21 See Foster chapter 5 for a full account and contextualization of Marx's concept of metabolic rift. 
having ever studied on what the security of my life and the foundation of my prosperity were established. (Letters 188)

James here recognizes that the institution of property that supports his ideal of "independence" is not, as Locke claims, a "natural right," but an historically contingent social construction, and a fragile one at that. The outside world's incursion onto his farm impresses the inevitability of interconnection with larger society, and James rejects the emerging United States for the violence its worship of property and the market can wreak. Unwilling to support the marketdriven revolutionaries, either in war or as an inevitably connected neighbor, James resolves to move his family to the "stronger" "circle" of an unnamed Indian village, whose ecologicaleconomy is oriented toward agrarian subsistence rather than capitalist commerce. Ultimately, Indian economies emerge in the text as a more just, peaceful, sustainable, and coherent articulation of American agrarianism than the oft-anthologized Letter III.

Critical reception of the Letters' end has been mixed, with some readers taking James' decision as a legitimate choice that at least somewhat resolves the work's earlier tensions, and others viewing it as yet another naive romantic construction of a utopian life yet one step "closer to [a] Nature" that can never truly be accessed (Letters 199). DH Lawrence calls James' choice a "swindle," noting with disdain that Crèvecoeur himself chose the "commerce" of Europe, leaving his wife to be massacred by the Indians that James reveres (35). Elayne Rapping writes that though the Indians "offer a version of reality more secure, more rational, and more consistent" than James' model agrarianism, "the life of the Indian does not of course represent a real opinion. It is another fictitious model of reality which Crèvecoeur uses for contrast" (718). In the terms of this study, one might view James' actions as a temporary pastoral retreat from the complexities of commercial life. Yet other critics, including Jehlen and David Robinson, give James more 
credit, the latter writing that the Indian village is "a place of refuge to which James can transport the essential values of his agrarian life" (23). I am not sure that all of these views are mutually exclusive. Crèvecoeur clearly establishes James as possessing a character common to American farmers: an impossible idealism paired with eminent practicality. Any decision forward for James would involve romantic notions, yet also decisive action. American Indians were always conceptualized in romantic and unrealistic ways, yet, as James himself points out, many whites historically joined Indian society with those romantic notions in mind: James' decision is both realistic and idealistic. A larger problem with most treatments of the Letters' end is that they fall into the essential trap of Modern thinking by conceptualizing James' choice as one between "civilization" and "nature." Even Christine Holbo's excellent article on Crèvecoeur's "politics of associationism" reads the final letter as "pointing toward a further reconciliation of European man with originary Nature" (55). This view of James' choice perpetuates the modern myth of an ontological separation between culture and nature, and in so doing participates in the problematic trope of the "Ecological Indian" by de-culturalizing Indian populations.22 James, the Enlightenment man that he is, also figures his choice this way, but we can benefit from the insights of postmodern ecocriticism to conceptualize — and judge-his decision more accurately. James' true choice is not between "civilization" and "nature," but between two different systems of ecological-economy. Pre-contact Indian landscapes were cultural and economic spaces as socially complex as the European communities which would supplant them, and considerably more ecologically complex in their multifaceted interconnection with various environmental systems. Crèvecoeur does not specify to which particular nation Farmer James intends to emigrate, but from his mid-Atlantic location we can assume some knowledge of their

22 See Kretch for a full critique of the "Ecological Indian" trope. 
agricultural practices. Rather than the independent farmsteads and stationary towns of Crèvecoeur's mid-Atlantic, in which $100+$ acres were needed to support one family, native communities of the area were organized around the life of small mobile villages, which relocated according to hunting, gathering, and growing seasons. Northeastern Indian agriculture relied on burning to replenish soil fertility, and was oriented around diverse companion plantings of staple foods, such as the three sisters of corn, squash, and beans. Whereas European immigrants used the same improvement techniques of draining, clearing, and raising monocultural cash crops throughout North America, Indian agriculture was extremely varied and diverse, because it was responsive to climate and ecological community. And importantly, agriculture was only one aspect of Indian ecological-economy, and was augmented by gathering, hunting, trade, and barter. Because of this diversity, "many, indeed most, and perhaps all, of the farming practices employed by aboriginal North American farmers were sustainable. The natural environment was transformed, but what replaced it was ecologically sound" (Doolittle 4).23

Crèvecoeur frames James' choice in the same sort of ecological-economic language that characterizes the cultural and geographical analysis of his earlier letters. James writes that Indians "live with more ease, decency, and peace, than you imagine; who, though governed by no laws, yet find, in uncontaminated simple manners, all that laws can afford. Their system is sufficiently complete to answer all the primary wants of man, and to constitute him a social being, such as he ought to be in the great forest of nature" (196). Far from a pastoral retreat, James articulates his plans in the georgic mode of economic analysis and action: the Indian

23 Debate over the extent to which pre- and/or post-contact American Indians were "sustainable" or "ecologically sound" is a vibrant: see Kretch and Harkin and Lewis. Yet there is no doubt that in Crèvecoeur's late eighteenth-century mid-Atlantic Indian agricultures were more sustainable than white ones, nor that this was largely due to the Indian lack of the profit motive of Modern capitalism. 
"system," as he sees it, both answers to the economic "wants of man," and also attends to how they "ought" to exist with regard to the ecological context of the "great forest." "Simple" is one of Crèvecoeur's favorite adjectives and prime virtues, contrasted often with European cities and the market relations that guide them. The American farmer of Letter III is a "simple" one, as are the Indians of Letter XII, who "most certainly are much more closely connected with nature than we are; they are her immediate children; the inhabitants of the woods are her undefiled offspring; those of the plains are her degenerated breed" (Letters 203). By contrasting Indians and Europeans as the people of the "woods" or the "plains," Crèvecoeur explicitly identifies their ecological-economies as their defining difference, and labels the former as "more closely connected with nature," or with their nonhuman environment. European economy, by contrast, is "the fictitious society in which we live," taking its guidance not from "simple" and immediate ecological systems, but from the demands of a distant urban market (Letters 202).

Yet James' solution is incomplete - the Letters end before we learn the results of his plan-and possesses some of the same contradictions of his earlier agrarian vision. Though James wants "to conform" to Indian life "as a sojourner, as a fellow hunter and laborer," he also endeavors to change his new neighbors (215). James retains his foundational georgic and agrarian belief that "the simple cultivation of the earth purifies," and is critical of Indian reliance on hunting, which he perceives to inculcate sloth. As such, he seeks to "persuade" the Indians "to till a little more land than they do, and not to trust so much in the produce of the chase" (Letters 210). To inspire industriousness in his children, James devises a credit scheme to account for their labor, which he will pay "at the return of peace" (Letters 212). James seems thus still conflicted about how closely to tie himself to the market. He "intends to procure but a simple subsistence," and plans to "endeavour to make [the Indians] regulate the trade of their village" so 
as to discourage the exploitative "pests" of traders, but is unwilling to fully commit to the cultural changes such an economic life entails (Letters 210-12). At Letters' end James continues to hunt the elusive "middle landscape": his plan is not an abandonment of the logic of American georgic, but an attempt to shift it away from commerce, and toward subsistence. Though James is an idealist, he is no purist, and ultimately recommends a hybridization of Indian and European agriculture and economy that can combine Modern improvements in technology and yield with the Indian subsistence motive.

James suggests that such a blending will require American agrarianism to shed its attachment to an impossible standard of independence, and to reground its georgic discourse in a collective economic structure. He writes at the outbreak of the Revolution that "I resemble, methinks, one of the stones of a ruined arch, still retaining that pristine form that anciently fitted the place I occupied, but the centre is tumbled down; I can be nothing until I am replaced, either in the former circle, or in some stronger one" (Letters 198). James recognizes his "philosopher's stone" of independence was always an illusion, and that rebuilding a better American economy post-war will require a "stronger" structure, in which the ecological-economic connections between individuals and families are not hidden, but explicit. Crèvecoeur here treads rhetorical ground similar to that of the Cherokee in the 1820 s as they fought for recognition as a nation. Sweet traces how the Cherokee "invoked the radical potential of the American georgic" to "develop an agrarian economy and sustain sociopolitical cohesion by defining their resource base as national, rather than a set of individual possessions" (Georgics 10). Sweet writes that "the Cherokee's loss depleted the American environmental heritage by removing a significant model for conceptualizing land use in terms of the public good. If they had not been removed, Cherokee farmers, counting on plenty of tillable acreage in a national reserve, without the complications of 
property ownership, could have provided a historical model for sustainable agriculture" (Georgics 152). Had Crèvecoeur himself followed James' path, perhaps his agriculture could have too.

V.

To read Crèvecoeur in this way is to imagine an American history in which Indian economies, knowledge, and populations were incorporated into the United States rather than excised. Yet the destruction of both Indian and white subsistence agrarianism was assured by the urban-industrial turn in Europe, before colonization even reached American shores. After the revolution, Crèvecoeur's mid-Atlantic and northeast began to industrialize, with wage-based manufacturing and heavy industry subsuming agrarianism as the dominant mode of ecologicaleconomy. In the south, industrial plantation agriculture expanded in scale and moved westward into the lower Mississippi valley. Agrarian market opponents most often followed neither Crèvecoeur's path to Europe nor James' to Indian villages, but instead west, where the early stages of the cycle of capitalist development still permitted the establishment of the agrarian "middle landscape" between wilderness and urban civilization.24 Yet these spaces were always temporary, permitted to exist in upland Appalachia only until the arrival of the timber and coal industries, and in the upper Midwest only until oil-fueled mechanization unleased large-scale monocultural cultivation of grain and soy. The steady march of industrialization brought with it a corresponding expansion of urbanization and pastoral consciousness, while the georgic mode of agrarianism slowly receded as farmers were forced off their land and into the wage economy.

Yet despite its brief, tenuous existence and its many internal tensions, American agrarianism — and georgic discursive mode in which it is expressed - remains to this day a

24 See Robinson on the role of the frontier and westward expansion in Crèvecoeur. 
popular and influential ideological force, and the mythic image of the yeoman farmer a potent cultural symbol.25 It has been invoked by countless individuals and groups across the political spectrum to support programmes as diverse as the Confederacy and Chinese exclusion to Prairie Populism and leftist environmentalism. After Crèvecoeur, agrarianism's next great reimagining occurred in the Transcendentalist moment of the 1820s and beyond, as agrarians issued more explicit georgic challenges to urban industrialization, and figured themselves less as the tip of the Modern Enlightenment experiment than as a return to the pre-modern culture of the land. While Transcendentalism and Romanticism more broadly laid the foundations for twentieth-century environmentalism, Transcendentalist agrarianism presented its initial economic arm, and has served as the inspiration for the popular and recurrent back-to-the-land movements of the following centuries. The trajectory of agrarianism through Crèvecoeur's agrarianism and the Transcendentalists' lives on both ideologically and physically, for Crèvecoeur's Pine Hill Farm in Chester, New York is still in operation. The land that he drained to raise corn and flax today is nurtured with biointensive practices to grow a diverse mix of organic peaches, berries, vegetables, and herbs for sale and barter in the local community (Pine Hill Farm).

25 See Smith for a seminal exploration on the role of the frontier in the literary establishment of the myth of the yeoman farmer. 


\section{Thoreau's Transcendental Georgic}

After the Revolution, the United States was no longer a subservient colony, bound to producing raw materials for export to manufacturers across the Atlantic. Despite Jefferson's agrarian call to "let our work-shops remain in Europe," American capitalists recognized that industrializing the home economy presented wide and vast opportunities for wealth creation (171). While some of the children of Crèvecoeur 's generation of yeoman farmers set out west to clear forests into farmland, others remained near the coast, where export profits no longer taxed by Britain could be deployed in industrial processing schemes, from timber, iron, and grain milling to textile production and gunsmithing. As networks of canals, railroads, and roads snuck across the countryside, transporting people, materials, and products faster and cheaper, factoryproduced goods began to replace agrarian home manufactures, and failed farmers and landless sons found ready work in burgeoning industrial towns. By the 1830s, American capitalism had found its footing, corralling the economic structures of farm, family, and community under control of the international commerce. Jefferson's archetypical yeoman agrarian was replaced with Jackson's "common man," now untethered from the land and free to seek wealth in the new arena of the marketplace. 2627

America's first major literary movement positioned itself against these developments in cultural economy, perceiving industrialism to effect a broad alienation from "Nature" by substituting the dollar for the divine. Transcendentalism recognized that the non-market structures of early American agrarianism had the potential to serve as a bulwark against

26 This chapter draws on Horrocks, "Planting-out after Blithedale." 27 See Gilmore's American Romanticism and the Marketplace for a full treatment of the transition from agrarian to commercial society in American literature. 
industrial forces, and championed various agrarian programs — such as Brook Farm, Fruitlands, and Walden — as the economic arm of their broader movement. Rather than defending medieval agrarian values at the modern turn, like Burns, or adapting those values to the new American wilderness, as did Crèvecoeur, the Transcendentalists were the first generation to articulate agrarian values from within a thoroughly industrialized economic landscape.

Yet some Transcendentalist agrarian efforts, satirized well in Hawthorne's Blithedale Romance, were limited in their effect by a pastoral, utopian impulse that was more invested in conceptualizing an agrarian society than in working to build one. Scores of critics and environmentalists have since similarly read Thoreau's Walden as an idealistic pastoral. Though most credit his work as the prime example of American "complex pastoral," to be lauded in its articulation of the intricacies of the American cultural relationship to environment, others view Thoreau as presenting a critique of industrialization that, though incisive, ultimately relies on and reinscribes market relations in a pastoral "retreat." Yet all these critics are misled by their own leisure-class tendency to view environmental literature through a pastoral lens, even though Thoreau's instructional intent and preoccupation with the economic nexus of nature and culture suggest rather a georgic form.

When read as georgic, Thoreau emerges as an energetic participant in the contemporary convening of "economy" as a discipline and social concept, breaking with the likes of Smith and Jefferson to define economy as environmentally determined and ecologically enmeshed. As georgic, Thoreau's work further prescribes a set of economic actions that remain an effective blueprint for agrarian practice within the industrialized economy. Like Burns, Thoreau recognizes that alienation from regular extractive labor effaces regular "acquaintance" with nonhuman beings and networks, creating a self-reinforcing cycle of pastoralization. Thus, in 
Walden, and especially his unfinished georgic almanac Wild Fruits, Thoreau recommends individuals and communities to move beyond critique of industrial economic relationships by withdrawing from their influence, and reconstructing nonmarket agrarian economies in their stead. Though Thoreau's transcendental agrarianism was unable to restrain the hegemony of industrialism and pastoral thinking in U.S. expansion, his activist prescription inspired countess successful marginal agrarian communities, and remains an effective strategy today.

I.

Toward the end of the first chapter of Emerson's Nature, while "crossing a bare common," his "head bathed by the blithe air, and uplifted into infinite space,_-all mean egotism vanishes. I become a transparent eye-ball; I am nothing; I see all; the currents of the Universal Being circulate through me; I am part or particle of God" (10). These lines suggest Transcendentalism is a tributary of ecocriticism, and early incubator of ecocentric attitudes. For when the "mean egotism" of humanism "vanishes," Emerson receives "the suggestion of an occult relation between man and the vegetable," effacing the conceptual divide between nature and culture, body and mind (10). Both ecocriticism and Transcendentalism positioned their ecocentrism against similar forces in modern industrial society that they saw as further separating humans from their environment. Robert Gross writes that early 19th-century Concord, rather than the sleepy intellectual town as which it's often portrayed, was actually at the center of antebellum New England's turn from subsistence farming to "agricultural capitalism," and situates Transcendentalism as responding to this socio-economic revolution. Though the primary exigence of today's environmentalism is socio-ecological pollution, most ecocritics recognize that problem to be caused by the excesses of that same industrial turn. Both movements are thus 
activist, hoping that their articulation of an ecocentric ecological ontology can spur positive socio-economic developments.

But the lines directly following Emerson's famous image illustrate one of the central problems of both ecocriticism and Transcendentalism. For as that "transparent eye-ball," Emerson relates that "the name of the nearest friend sounds then foreign and accidental: to be brothers, to be acquaintances, - master or servant, is then a trifle and a disturbance" (10). Emerson's unsettling observation reveals the tendency for both movements' ecological visions to efface social obligations, rendering them a mere "trifle and disturbance" to the grander—and easier-philosophical project of ontological speculation.

Ecocriticism has been less ambitious than Transcendentalism in tackling the problem of socio-economic application. The introduction to this dissertation details the ways in which environmentalist overreliance on pastoral ideology leads to a thematic elision of labor and economics, in much the same way Raymond Williams has shown eclogues to gloss over the labor that sustains their celebrated landscapes. Ecocriticism's near total neglect of the Transcendentalists' socio-economic experiments indicate the field's reluctance to wade into the thick and sticky waters of applying its own theorizations. This elision is even more striking given the otherwise importance of Transcendentalists to the development of ecocriticism, especially its most activism-oriented member, Thoreau. Yet the ecocritical focus on the topic remains perceptual and ontological, focused squarely on how writers conceptualize nature, and too often ignoring the economic engagements and labors those conceptualizations inspire. Because the broader literary studies establishment is also a product of urban, pastoral ideology, it too tends to neglect issues of work. As Nicholas Bromell writes in By the Sweat of the Brow, even the Marxist historicism that dominated late 20th-century literary studies "has been signally 
uninterested in the subject of work. Instead, it has focused almost exclusively on economic exchange, applying with rich results a Marxism of the marketplace but omitting to discuss in much detail the very activity which brings a market...into being: work" (4). One example of this tendency is Richard Francis' Transcendental Utopias, the only full treatment of the topic in literary studies. Though Francis recognizes that individual and community reconciliation is the essential tension of Transcendentalism, his philosophical focus neglects the role of labor, economy, and ecology within the utopians' attempts to address it. An important exception to this trend is Lance Newman's 2006 Our Common Dwelling, which appreciates ecocriticism's need for an economic theory, and the lessons Transcendentalism can offer to its development-I hope this chapter can add depth and weight to his call by bringing the role of pastoral and georgic discourse into sharper focus.

But modern literary critics are not alone: Transcendentalists too struggled with the extent of their obligation to advocate and create social improvement. Their standard-bearer Emerson, though perturbed by social injustice, remained more concerned with his "central project" of "unchain[ing] individual minds," and was reluctant to permit this philosophical interests to become bogged down in the difficulties of social implementation (Buell Emerson 9). Yet, as Perry Miller writes, other Transcendentalists maintained that their "metaphysics led inescapably to a social philosophy and to a critique of existing institutions" (72). Newman characterizes this divide as one "between reformers and scholars" (110). Many in the former camp, such as Brownson, Channing, Peabody, and Ripley, utilized Transcendentalist criticism to push back against the industrialization of their communities and the US nation, advocating for causes from abolition and women's rights to the elevation of the working class. Most ambitious among these reformers were the utopians, who founded socialist agrarian communities such as Brook Farm 
and Fruitlands to transform Transcendentalist ideals into reality. Francis writes that the utopians sought to "connect the eternal world of nature and natural law ... with the dynamic world of history and contingency. ... Utopias provide the bridge the Transcendentalists were seeking, for they are situated exactly halfway between the ideal and the real" (xi). The Transcendentalist utopians are one node in a long tradition of socialist agrarian communities in America stretching from the present back to Bradford's Plymouth Plantation, which also rebelled against the commercial excesses of modernizing England, seeking a more foundational relationship to God in a simpler, agriculturally-based community.28

Though the Transcendentalist utopians differed widely in their particular convictions and social plans, they shared a belief that agrarian practice could counteract industrialism, their common foe. Newman writes that "efforts to engage in handiwork preoccupied most of the members of the broader Transcendentalist movement," and farm labor served as the economic basis for all of their utopian experiments (124). Georgic engagement was the Transcendentalists' primary means of recognizing the single system of order they found to be inherent within a total Nature including both human mind and historical society. Emerson writes in "Musketaquid," for example, that "the order in the field disclose / the order regnant in the yeoman's brain"; and in "Man the Reformer" that "we must have a basis for our higher accomplishments, our delicate entertainments of poetry and philosophy, in the work of our hands" $(50-1,150)$. Statements such as these have led critics like Paul Thompson to claim that by the end of his career, Emerson "came to see the farmer as more truly expressing the potencies of nature than even the poet" (57).29 This is because the georgic act entails, indeed requires, the physical, mental, and spiritual

${ }_{28}$ Shi traces this impulse for agrarian simplicity throughout the American Experiment in his 2007 Simple Life.

29 See Sarver for an extended analysis of Emerson's engagement with agriculture. 
connection of the spheres of body and mind, nature and history, that the Transcendentalists sought to retain in the face of the increasing division of labor foisted by industrialization. In the words of Bronson Alcott, gardening is "the intermingling of mind with matter, a conversion of the earth into man through the mind, the hands assisting" (344). And though Hawthorne and Emerson viewed utopian reforms pessimistically, they still praised agrarian life. Even The Blithedale Romance's pastorally-minded, labor-hating Coverdale finds in georgic activity "an unwonted aspect on the face of Nature, as if she had been taken by surprise and seen at unawares, with no opportunity to put off her real look, and assume the mask with which she mysteriously hides herself from mortals" (48). And though Emerson refused Ripley's request to join Brook Farm, he states in his reply that he will nonetheless seek to "acquir[e] habits of regular manual labor" in his own home and garden (Letters 245). These enthusiastic passages (and the persistent legacy of the agrarian tradition in the modern West) suggest that georgic engagement is a realistic and meaningful socio-economic application of Transcendentalism's ecocentric ontology: by working the land, those at Brook Farm and Fruitlands occupy the space at which nature and culture meet, their working lives becoming an integrative dance with the cosmos.

Yet, of course, it is important to note that all of the Transcendentalist utopian experiments failed. And even beyond their historical moment, it is much easier to find examples of failed intentional communities than successful ones. But the frequent collapse of utopian-socialistagrarian projects is not due to their agrarianism. The Transcendentalist experiments were surrounded by economically successful and sustainable agrarian communities, and agrarianism is today practiced in a variety of modes and locations around the US and the world. The problem with utopian projects is that they are too often rooted in pastoral ideology. By operating in the 
pastoral mode, these communities project a conception of an ideal relationship between agriculture, nature, and society upon what they perceive — in typical American fashion —as a blank landscape void of human and ecological history. Though the Transcendentalists seek to unite nature and culture, their leisure-class pastoral perspective maintains their separation, and their utopian methods require an unsustainable detachment from the existing eco-social order. II.

Hawthorne's satire of Brook Farm, The Blithedale Romance, illustrates how the utopians' pastoral thinking leads to their ultimate demise. Hawthorne endows his narrator-a young poet by "trade"—with a particularly pastoral attitude that he suggests is typical of the Blithedalers, and through which readers are forced to receive the novel's action. Even his name, Coverdale, suggests that he suppresses the actual landscape with his own imaginative ideals. Yet Coverdale, whose citation of Virgil's Georgics assures us of his familiarity with the mode, is sensible to the Blithedale farce, and remarks upon his early arrival that "our heroic enterprise [shows] like an illusion, a masquerade, a pastoral, a counterfeit Arcadia, in which grown-up men and women were making a play-day of the years that were given us to live in" $(47,17)$. The remainder of the novel demonstrates the particularly pastoral mode of this "play-day," and suggests its consequences in its tragic ending.

Hawthorne criticizes Blithedale (and by extension Brook Farm) most obviously through the character of Hollingsworth, whose dedication to his "philanthropic theory" engenders an ironic egotism and hypocrisy. Coverdale considers devotion to specific ideas of social reform an essentially selfish enterprise in which otherwise benevolent and kind souls become narcissistically wedded to the execution of their own achievements, distorted from social good to personal goal and eventually leading to an "all-devouring egotism." And at Blithedale, it is 
pastoral thinking that underwrites this process. The utopians are consistently more concerned with crafting intellectual conceptions of the ideal relationship of human to nature than in participating in the actual economic agrarian work that connects the two spheres. Coverdale explains,

while our enterprise lay all in theory, we had pleased ourselves with delectable visions of the spiritualization of labor, ... each stroke of the hoe [promising] to uncover some aromatic root of wisdom ... [I]n this point of view, matters did not turn out quite so well as we anticipated. . . . Our thoughts ... were fast becoming cloddish. Our labor symbolized nothing, and left us mentally sluggish in the evening. (47-8)

Rather than bridging the work of the body and mind, nature and culture, as the community seeks to do, Coverdale's description of their labor draws a sharp pastoral distinction between them. For the Blithedalers, labor is useful only in the extent to which it "symbolizes" a "spiritual" "root of wisdom." Indeed, the extent to which agrarian work interfered with Hawthorne's individual intellectual pleasures was the primary reason he left Brook Farm, leading him to state famously that "labor is the curse of this world, and nobody can meddle with it, without becoming proportionally brutified" (Letters 558). The problem with this view is, of course, that shared labor is the essence of the socialist relationship the community seeks to foster. Without participating in that labor, an individual hypocritically and pastorally separates his ideals from his daily economic practices, which continue unabated regardless of the rigor of one's internal intellectual activity. More troubling, excusing an individual from labor, especially for the mere purpose of personal pleasure, re-creates the very inequities the scheme seeks to ameliorate; it is by ceasing labor that Hawthorne "brutifies" those who must perform it for him. Coverdale's critique of Hollingsworth's philanthropy is thus aptly directed at Blithedale itself, as its 
practitioners' commitments to socialist ideals become "false deities" that reflect merely their desire for social change, and not their willingness to make personal economic sacrifices for it (51).

This individual detachment between ideals and practice provides a crooked foundation for the ecological-economic ties that must bind the community to itself, and to its broader context. Since the Blithedalers sell their agricultural products in the local markets, the very labor upon which their connection between mind and matter is predicated is itself a direct interaction with the traditional economic systems they seek to transcend. But beyond that irony, as Coverdale notes early in his stay, "as regarded society at large, we stood in a position of new hostility; rather than new brotherhood" (17). This problem also plagues many revolutionary socialist movements: the initially universal values of liberté, égalité, et fraternité grow more and more limited in scope as they are forced to exclude those who inevitably disagree. And though Blithedale was no violent revolution, its lofty Transcendentalist rhetoric of reform necessitated the Othering of outsiders, who take the ironic form not of wealthy Boston merchants or politicians but neighboring farmers, those who have been practicing for their entire lives the georgic connections between nature and culture the Blithedalers wish to foster anew.

The absurd hypocrisy of the Blithedale project is captured well in the climactic scene of revelry Coverdale finds upon his return to the farm. Rather than working the fields, where Coverdale expects them, his former companions are masquerading as a motley assortment of Indians, shepherds, and mismatched gods and goddesses, attempting the creation of new traditions which, while enjoyable, are mere childish play, in which one pretends to live a life one does not. Silas Foster, the working-class farmer who manages the actual operations of Blithedale, simply looks on, doing "more to disenchant the scene" in his reminder of economic reality "than 
twenty witches and necromancers could have done, in the way of rendering it weird and fantastic" (145). As Coverdale attempts escape of these "chimaeras," he finds himself stumbling over a heap of logs and sticks that had been cut for firewood, a great while ago, by some former possessor of the soil. ... But, being forgotten, they had lain there, perhaps fifty years, and possibly much longer; until, by the accumulation of moss, and the leaves falling over them and decaying there, from autumn to autumn, a green mound was formed, in which the softened outline of the wood-pile was still perceptible. (146). Yet this georgic image, a reminder of the cyclical context of natural economic reality, of relation between trees, humanity, climate and death, can last only momentarily for Coverdale, who is quickly drawn back into the romantic windings of the novel's plot. The only thing that can truly shake the Blithedalers out of their agrarian masquerade is the death of one of their own, Zenobia, whose suicide represents the ultimate, tragic break with reality, the inevitable end of an unmoored life. Coverdale early states that he "shall never feel as if [Blithedale] were a real, practical, as well as poetical system of human life, until somebody has sanctified it by death" (91). Zenobia's demise, however, ironically wrenches the community back into the old system, as the Blithedalers' plans for elaborate new burial traditions are eschewed in the moment, Zenobia ultimately "buried very much as other people have been, for hundreds of years gone by" (163). Blithedale seeks to efface the distinction between history and nature, mind and matter, philosophy and economy, yet its pastoralism cognitively separates these spheres, denying the extent to which these elements are already firmly intertwined in the cosmic economy of which we are all a part, their cooperative play rendering the distinctions between them already meaningless. 
III.

Yet Transcendentalist agrarianism was not limited to the pastoral utopian strategy of Brook Farm. Newman writes that "Thoreau and the Brook Farmers were far closer in their thinking about society and the meaning of leaving it than it has been common to admit" (136). Beyond being acquainted with many of the individuals and ideas behind Brook Farm, Thoreau visited their site in 1843, and, according to Newman, "saw himself as engaged in a vitally important conversation with the utopian socialists there" (136). But though Thoreau shared the concerns and general philosophical orientation of the broader Transcendentalist movement, his application took a different tack than that of the utopians. Thoreau refused to join Brook Farm despite many entreaties, writing in his journal that he would "rather keep a bachelor's room in Hell than go to board in Heaven" (227). We can thus read Thoreau's 1845 Walden experiment as a response to the Brook Farmers; in Newman's words, "both [Walden] the book and the retreat was an attempt to answer the socialists by putting into practice Emersonian ideas about the pedagogy of nature, cultural leaders, and national revival" (137). The remainder of this chapter argues that Thoreau's social experiment was superior to the Brook Farmers' in effect and legacy because it operates not in the pastoral, but the georgic mode, as do all successful agrarian communities. Rather than seeking to construct a new, ideal relation between man and environment, Thoreau's georgic begins with historical knowledge of the local ecology, and crafts practice and recommendations with the goal of submitting human economy to that context. His Walden thus attempts to bring a georgic sense of economic reality to the utopians' pastoralized dreams.

However, the vast majority of the overwhelming amount of literary and environmentalist criticism of Thoreau instead assumes his work to participate in pastoral, a misreading that has 
constructed the dominant critical debate surrounding his work and its impact. As chapter one of this dissertation elaborates, this critical tendency is by no means unique to Thoreau, and is due largely to the dominance of pastoral thinking in American culture; urban critics have so internalized pastoral ideology that they have difficulty apprehending any conceptualization of the environment beside it. But the case of Thoreau is particularly significant because of Leo Marx's influential depiction of Walden as the prime example of American "complex pastoral," which he argues is a version of the mode that recognizes and grapples with its essential tensions between man and nature, real and ideal, ecology and art. Most criticism of Thoreau has assumed Marx's conception of Walden as pastoral, which Lawrence Buell imported into ecocriticism in his seminal Environmental Imagination. Accordingly this reading of Walden as pastoral has framed the major debate surrounding Thoreau: is he a visionary proto-environmentalist whose work articulates and addresses the key tensions of the industrial conception of nature? Or, as scholars such as Michael Gilmore have argued, is the experiment at Walden a fleeting pastoral retreat from the complexities of modern life that ironically relies on and reinscribes the very commercial relations it posits itself against? For Gilmore, the pastoral "aesthetic strategy" Thoreau "adopts to accomplish political objectives involve him in a series of withdrawals from history; in each case the ahistorical maneuver disables the political and is compromised by the very historical moment it seeks to repudiate" ("Curse of Trade" 223). Walden is thus a "defeated text," "limited" by its "complicity in the ideological universe he abhors" (ibid. 224). Scores of popular critics—and disaffected undergraduates - have leveled similar critiques at Thoreau, who is often imagined as a hypocritical faker; as one farmer friend once asked me: "isn't he the guy who pretended to live off the land but really went home every night to eat dinner and do his laundry?" Both of these positions depend on the assumption of Thoreau's participation in the pastoral convention of 
retreat-and-return. In the positive reading, Thoreau' sojourn at Walden supplies him with "lessons from nature" that readers can apply in their urban lives; in the negative one, these lessons are insufficient to meaningfully effect an always already industrialized economy.

But both sides of this argument miss the extent to which Walden's "pastoral complexity" is achieved by importing georgic conventions, assumptions, and thematic concerns.30 Several recent scholars have recognized this, and penned essays seeking to recover Walden's georgic components.31 Michael Ziser, for instance, allows that pastoral is "a vital framework for understanding Walden [and] American literature more generally," but recognizes that pastoral also suffers from a "procrustean overextension" that inhibits consideration of alternate modes of engagement with environment (171). Ziser writes that, aside from Thoreau's enthusiastic familiarity with the formal georgic of the classics,

the notion that Thoreau was a hands-on agrarian writer makes a kind of intuitive sense, as Walden not only inspired but even served as a guide for countless back-to-the-landers whose experience has been, and was in conception, as much georgic as pastoral. ... indeed many critics, Stanley Cavell most persuasively, have understood Walden as at base a deeply didactic how-to manual for leading the philosophical life, a georgic of selfinquiry. The historical argument for Walden as emerging from and feeding into a georgic tradition is thus as strong as or stronger than the pastoral lineage fancifully sketched by Leo Marx and left unquestioned by most subsequent scholarship. (177) 32

${ }_{30}$ Critics often find that "complex pastoral" texts engage in a "darkening" or "hardening" of pastoral, or an "anti-pastoral," yet neglect the way this effect is achieved by importing georgic conventions; see introduction.

31 See Tillman for Thoreau as georgic.

32 See Sattelmeyer for Thoreau's familiarity with classical georgic. 
Accusing Thoreau of hypocrisy only makes sense when one views his work as pastoral, and from a pastoral perspective. The existence of hypocrisy depends on a speaker establishing and recommending an ideal, and then failing to live up to it through action. And in the pastoral reading of Walden, Thoreau does just this: for example, despite lauding simplicity and selfprovisioning as a means of diminishing the negative influence of industrial commerce, Thoreau himself purchases and eats rice while at the Pond. But Thoreau's Walden is no Brook Farm; Thoreau is not seeking to construct an utopian theory, nor enact such a society. Whereas pastoral asks and judges whether an idealization can be enacted, georgic explores how we can act best now from within our current local ecological-economic situation.33 Rather than basing action in idealized theories, georgic conditions actions upon its apprehension and acquaintance with the nonhumans comprising the local environment. From a georgic perspective, that Thoreau maintains connections to the industrial human economy is not hypocrisy, but inevitable. The georgic critic will judge Thoreau not on the pureness of his intentions, but the outcomes of his actions, and Thoreau's mere purchase of rice renders his overall economy still considerably less industrial than even the Brook Farmers. As Seth McKelvey recognizes, "Thoreau's seemingly overt rejection of trade in Walden can be reconciled with his sustained acceptance and usage of market exchange throughout the two years he spent in the woods[;] Thoreau does not dismiss the principle of trade in general, but rather trade as a specific 'occupation."' (449). As my added

33 Here I refigure Ziser, who writes "the georgic asks not whether language can successfully jump up from a real original to an imitation, but how it can jump down from abstraction and land with a degree of efficacy upon some object in the world, becoming not just a mirror of nature or a lamp, but something more akin to a hoe or a shovel or a seed drill 'of nature'" (183). 
emphases suggest, Thoreau's georgic perspective is focused on altering his actual present labors to ensure better — not ideal—future outcomes for his entire ecological environment.

The georgic is the proper mode to pursue these aims because of its overwhelming thematic concern with the connection between economy and ecology. Accordingly, every draft of Walden began with its extended opening meditation on "Economy," which establishes the critical lens through which the remainder of the book explores the ecology of Walden Pond (Birch and Metting 587). More than merely considering economy as a literary theme, Thoreau's work uses the georgic to participate in the very convening of economy as a disciplinary category. Smith's Wealth of Nations was published only in 1776, and the works of Say and Ricardowhich Thoreau read and appreciated - appeared in 1803 and 1817, respectively. The tenets of the "classical economics" that we now associate with these writers were in the early 19 th-century far from settled; Thoreau engaged with these authors not as authoritative textbooks, but as recent theorizations of "natural philosophy." Thus we can consider Thoreau as not only critiquing Concord's economic situation from a humanistic perspective, but also as an economic philosopher himself.34 Harold Hellenbrand and Judith Saunders both make this argument by focusing on Thoreau's use of the vocabulary of business and economics.35 Hellenbrand writes that Thoreau "wakes" economic terms like profit, commerce, value, work, gain, and spend to "mean more," becoming "metaphors for forgotten spiritual and organic values" (69). Saunders views this "awakening" as subversion; by "availing himself at every conceivable opportunity of images and vocabulary with commercial connotations," Thoreau "exposes the insidious control exerted over our lives by the economic system of profit and loss which we so easily take for

34 See Christian Becker for a thorough treatment of how Thoreau responds to specific economic philosophers and concepts. 35 See also Stanley Cavell for a philosophical exploration of Walden's economic discourse. 
granted" (59). Though Saunders' analysis is apposite, it misses the extent to which Thoreau also employs economic language in earnest, as a convention of the georgic mode in which he operates.

Thoreau's economic language does more than merely critique the dominant modern conception of economy, but constructs, arguing for the essential georgic insight that economy is ecologically enmeshed and environmentally determined. He writes in Walden that "even the poor student studies and is taught only political economy, while that economy of living which is synonymous with philosophy is not even sincerely professed in our college" (52). Thoreau here labels the typical conception of "economy" (then and now) as "political," in that it is concerned solely with human production, trade, and consumption. Thoreau's ecological conception of economy is much wider, comprising all that is "living"; his economic vision is not of humans exercising political control over resource distribution, but instead an ecological network in which those resources push back, themselves exerting power and influence over each other and their human partners. Economics for Thoreau thus transcends human politics, and becomes "synonymous with philosophy"; Hellenbrand writes that Thoreau's idea of economy is "compacted" with meaning, "fus[ing] together the commercial, political, and dietetic activities of human life" (78). In this sense, Thoreau envisions economy as overdetermined, not treating merely one aspect of human community, but a set of concerns that effect, and are effected by, all other life on earth. The economist Christian Becker summarizes Thoreau's contribution to the discipline of economics as "a remarkable, early ecological critique of the modern economy and modern economic thought," and places his work as foundational to today's nascent discipline of 
"ecological economics," which attempts to revise the same classical economic models Thoreau critiques to recognize ecological enmeshment.36

Yet Thoreau's expansive definition of economy as overdetermined recognizes not only that the human conception of economy influences its incarnation, but also that human economic activity itself inculcates certain economic understandings. Thoreau's writing thus advances the essential claim of most georgic and agrarian discourse: the recognition of the economy's ecological basis is inculcated in the individual mind through economic and discursive engagement in the georgic mode of labor. This is because the georgic always entails what Thoreau calls "acquaintance" with nonhuman forms of life. Thoreau explores this "intimacy" most directly in his chapter on "The Bean-Field," which he begins by asking "what shall I learn of beans or beans of me?" (155). The georgic act of extracting energy from environment requires sustained cooperative and adversarial interaction with an entire ecosystem: in the case of the bean-field, crop, weed, soil, sun, insects, water, microorganisms, and resident mammals. Attention must be paid to all of these actors, not as pastoral nonhuman objects to be appreciated, but as a georgic subjects with which the farmer must communicate. Thoreau writes, it was a singular experience that long acquaintance which I cultivated with beans, what with planting, and hoeing, and harvesting, and threshing, and picking over and selling them ... Consider the intimate and curious acquaintance one makes with various kinds of weeds,--it will bear some iteration in the account, for there was no little iteration in the labor,--disturbing their delicate organizations so ruthlessly, and making such invidious distinctions with his hoe, levelling whole ranks of one species, and sedulously cultivating

36 See conclusion. 
another. ... Daily the beans saw me come to their rescue armed with a hoe, and thin the ranks of their enemies, filling up the trenches with weedy dead." (161)

This description of Thoreau's battle with the weeds is more than mere anthropocentric metaphorical projection, but an honest account of an economic encounter. In Thoreau's ecological-economic vision, weeding is an act of political economy, because the weeds are elevated to the rank of subjective actor. And it is the act of weeding itself that inculcates Thoreau's ecocentric paradigm; as David Robinson writes, "the growing web of connections with life in all its forms becomes apparent to him through his work" (339). While hoeing his beans, Thoreau interacts physically, economically, and consciously with the various beings comprising the ecosystem, and his success depends on his ability to apprehend their interdependences. In his words, georgic labor "cultivates acquaintance" with the nonhuman world; it is more than merely a pastoral awareness, but actual real-time/space interaction and communication with nonhuman actors. Thoreau is "determined to know beans" in the same way that he might know a human being (161).

Thoreau's celebrated ecocentrism consists of this acquaintance with the nonhuman; it is the "constant and imperishable moral" of "labor of the hands" (157). At the end of the "Solitude" chapter, Thoreau relays a transcendental experience similar to the one Emerson witnesses in Nature. Yet whereas Emerson's ensuing ecological vision is expressed in the pastoral mode, Thoreau's is in the georgic. The genesis of Thoreau's vision is in considering his agricultural activity, standing in his doorway amidst a "gentle rain which waters my beans," potatoes, and the wider ecosystem of the surrounding woods (131). While these georgic

thoughts prevailed, I was suddenly sensible of such sweet and beneficent society in Nature, in the very patterning of the drops, and in every sound and sight around my 
house, an infinite and unaccountable friendless all at once like an atmosphere sustaining me, as made the fancied advantages of human neighborhood insignificant, and I have never thought of them since. Every little pine needle swelled with sympathy and befriended me. I was so distinctly made aware of the presence of something kindred to me, even in scenes which we are accustomed to call wild and dreary, and also that the nearest of blood to me and humanist was not a person nor a villager, that I thought no place could ever be strange to me again. (132)

Far from surveying this scene as Emerson's disembodied "eye"/"I"—as exclusive pastoral subject - Thoreau's own bodily consciousness is enmeshed within the scene, exerting and receiving "sympathy and friendship" from the economic life surrounding him, and with whom he communicates: "the humanist blood" to him "was not a person." Emerson's experience is of an ecocentric ideal ("the currents of the Universal Being circulate through me; I am part or particle of God"), whereas Thoreau's is grounded in his "kindredness" with the nonhuman "friends" surrounding him. Rather than strangers seeming "a trifle and disturbance," as for Emerson, the enmeshment of Thoreau's georgic vision instead effaces strangeness in its recognition that he is "partly leaves and vegetable mould myself" (138). As put by Bromell, Emerson seeks to "affirm" the pastoral "ontological gap between body and mind, things and ideas, laboring and thinking," whereas Thoreau's georgic effectively "closes" it (7).

This georgic ecocentrism is the root of Thoreau's opposition to industrial commercialism, which he loathes because it removes nonhuman acquaintance and alienates environmental conception from georgic to pastoral. Gilmore writes that Thoreau's "quarrel with the marketplace is in large measure ontological. He sees the exchange process as emptying the world of its concrete reality and not only verting objects into dollars but causing their 'it-ness' or being to 
disappear" (180). This ontological shift is essentially a form of pastoralization; rather than being acquainted with nonhumans as mutual subjects, commodification objectifies, replacing the ding an sich with a mental ideal. Thoreau explains this process by example of one of his favorite beings — the huckleberry-in Wild Fruits: what sort of country is that where the huckleberry fields are private property? When I pass such fields on the highway, my heart sinks within me. I see a blight on the land. Nature is under a veil there ... Nothing could deform her fair face more. I cannot think of it ever after but as the place where fair and palatable berries are converted into money, where the huckleberry is desecrated. (58)

When humans purchase their food from the industrial system, an alienating "veil" of monetary commodification emerges between the two beings; in the terms of this dissertation, the human now knows nature as a pastoral object, rather than a georgic subject. Thoreau continues:

It has come to this, that A--, a professional huckleberry picker, has hired B-'s field, and, we will suppose, is now gathering the crop with the patent huckleberry horse-rake. C--, a professed cook, is superintending the boiling of a pudding made of some of the berries, while Professor D--, for whom the pudding is intended, sits in his library writing a book... And now the result of this downward course will be seen in that work, which should be the ultimate fruit of the huckleberry field. It will be worthless. It will have none of the spirit of the huckleberry in it. (58)

Thoreau's prescription for remedying this settlement is clear: he believes in "a different kind of division of labor," one not between human beings but within them: "Professor D—should be encouraged to divide himself freely between his library and the huckleberry field" (58). Here 
Thoreau's georgic mode issues an agrarian command, in its call to reimport extractive georgic labor and discourse into common American life.

Thoreau's georgic revises early American agrarianism to suit the context of an already industrialized landscape. Rather than idolize Crèvecoeur 's American Farmer, Thoreau is quite ambivalent, and often outright opposed, to the dominant agricultural practices in the U.S.. To inherit a farm for Thoreau is a "misfortune," and farming itself is an "odious" profession ( $W$ 5, $J$ 7). Statements like these are one source of the critical misreading of Thoreau as pastoral: how can he be both an agrarian, yet also so critical of agricultural practice? Yet, as agrarian critic Montmarquet writes of Thoreau's thinking on the matter, in a statement that could be applied to any georgic writer, "virtue is certainly not the inevitable outcome of the efforts of farming; it requires special effort and attention in its own right" (56). This is certainly true of the antebellum plantations that are the predecessors of today's agribusiness industry, both of which apply industrial techniques to maximize yields at the expense of ecosystem and social health. Though early agriculture above the Mason Dixon was typically more focused on home provision than commercial export, by Thoreau's 19 th-century it too began to take advantage of cleared land, new processing markets, and steam power to practice in new industrial modes. Industrial modes of agriculture replace commonly held georgic perspectives with pastoral ones, facilitating exploitation of workers, landscape, and crops by objectifying them. Thoreau's agrarianism indicts such industrial agriculture on the same counts as today's New Agrarianism: "by avarice and selfishness, and a groveling habit, from which none of us is free, of regarding the soil as property, or the means of acquiring property chiefly, the landscape is deformed, husbandry is degraded with us, and the farmer leads the meanest of lives. He knows Nature but as a robber" $(W 165)$. 
Thoreau's agrarianism focuses less on the act of farming, than on reducing consumption and participating directly in the production of one's own "necessaries of life" (W 11). In many ways, Thoreau's agrarianism is more aligned with the ecological economies of American Indians than white settlers. Sayre's Thoreau and the Indians explores the origin of the similarities between Thoreau's calls for simplistic subsistence and Indian socio-economies, finding Thoreau to be "indeed the most Indian-like of classic American authors, a truth which is easily documented, even if it has been too frequently ignored" (ix). Applications of Thoreau's agrarianism could range from Thoreau's extreme experiment at Walden, to simply raising a garden, foraging for food, cutting firewood, or simple construction. Today we might call Thoreau's agrarianism homesteading or homemaking, which attempt to reorient the domus to be a space of production as well as consumption; to put the "eco" back in "economics." Thoreau writes that the commercial farmer "is endeavoring to solve the problem of a livelihood by a formula more complicated than the problem itself. To get his shoestrings he speculates in herds of cattle" ( $W 33)$. Yet if one can forsake commercial luxuries, living simply and eat[ing] only the crop which he raised, and raise no more than he ate, and not exchange it for an insufficient quantity of more luxurious and expensive things, he would need to cultivate only a few rods of ground ... and he could do all his necessary farm 
work as it were with his left hand at odd hours of the summer; and thus he would not be

tied to an ox, or horse, or cow, or pig, as at present. (W 55)37 38

Thoreau expands on this recommendation in his final, unfinished manuscript, Wild Fruits, which elaborates on his early statement that "as for farming, I am convinced that my genius dates from an era older than the agricultural" (WCM 45). The book is a georgic foraging handbook, an almanac comprised of entries on different wild, edible fruits. It presents a guidebook not for the leisured pastoral observer of botany, but for those who wish to engage the "wild" world economically. Foraging and consuming wild fruits, for Thoreau, is important "for the part they play in our education" — these activities provide individuals with a specifically georgic and economic acquaintance with nature that inculcates ecocentric environmental consciousness. Ziser writes that foraging is "the heart" of Walden's "georgic turn" in its "realignment of ideal human labor with the labor of natural creatures" (181-2).39 This is why "to live deliberately" Thoreau forsakes the purchase or letting of a farm and instead "went to the woods"; the forest is an ecosystem better suited to his agrarianism than cleared pasture ( $W 90)$.

37 Thoreau's calculation is supported by the research of John Jeavons, who has found that "biointensive" growing practices, which are based on traditional southeast Asian methods and focus on building deep, healthy soil, "can grow a vegan diet for one person for all year on as little as 371 square meters (4,000 square feet) at reasonably obtainable intermediate-level yields" (66). By contrast, "conventional mechanized chemical and organic agricultural techniques" require about 7,000 square feet to raise a vegan diet and 15,000-30,000 to raise the average diet of a US citizen (67).

38 See Gross' "Great Bean Field Hoax" for an analysis of Thoreau's engagement with the literature of agricultural improvement.

39 Anderson calls Thoreau's agrarianism "wild farming," yet his pastoral reading of Walden —and exclusion of the clearly instructional Wild Fruits-leads him to claim incorrectly that "Thoreau's insistence on wild farming is not principally a demand for the maintence of any actual agrarian life," but serves instead "as a figure or metaphor for the conduct of any life; indeed, Thoreau's texts seem to aim not at farmers, but at those who are the keeper's of a culture's ... intellectual and spiritual traditions" (158). 
The georgic, agrarian labors of homemaking are also politically radical in the extent to which they reclaim profit and economic activity from the industrial system, and directly re-write the economy to be less industrialized and more ecologically attendant. By circumventing the industrial marketplace and disengaging from commodification, Thoreau's georgic labors actively create and strengthen nonmarket economic networks. And when one cannot extract their own energy from environment, Thoreau demands the reduction of consumption- - simplicity, simplicity, simplicity!"—which has similar anti-industrial socio-economic effects (W 91). "Slavery and war and other superfluous expenses" of industrial society are "sustained by" and "directly or indirectly result" from the use of "coffee and tea and meat every day" (W 205). Refusing to purchase such commodities both denies financial support to the industrial system, and strikes at the pastoral ideological effects of commodification itself.40 Thoreau's agrarianism asks us thus to "cast your whole vote, not a strip of paper merely, but your whole influence"; to "let your life be a counter friction to stop the machine" (HL 73). Politically, Thoreau's agrarian activism supports and requires a radical return from the logic of private property to that of the commons. As Laura Dassow Walls writes in the preface to her biography of Thoreau, while he "is often said to have turned to 'Nature,' ... what he actually turned to was, more exactly, the 'commons' - spaces that, back then, were still open to everyone: woods, fields and hilltops, ponds and blueberry thickets, rivers, meadows, trails up nearby mountains, the long open beaches on the Atlantic shore" (xiii). The very existence of wild fruits to be harvested depends on the perpetuation and maintenance of common spaces. In this sense, the discourse of Wild Fruits simultaneously calls into being georgic practices of labor, an ecocentrism based in acquaintance, and a non-capitalist economic geography.

40 See Neely on the radicality of Thoreau's vegetarianism. 
This ability of Thoreau's writing to affect material change is the main strength of all georgic discourse. Newman writes that Thoreau's writing career veers from "idealism and individualism to materialism and communalism" (110). This chapter traces a similar trajectory from Transcendentalist philosophy, through its applied utopian projects like Brook Farm, to Thoreau's work itself. Pastoralism and utopianism both begin with theory, and attempt to meet it with practice. Georgic, on the other hand, begins with apprehension of local ecological-economic situation, and subjective acquaintance with the nonhuman actors that comprise it. Georgic practice is not aimed toward imagining nor achieving an ideal state, but with effecting immediate, positive changes through economic engagement with environment. Thoreau not only "envisions a [communalistic] alternative to capitalist ecosocial relations," Newman continues, but "attempts as well to convoke it, to call it into existence by encouraging the ritual harvest and consumption of Wild Fruits" (116). Thoreau's georgic_-all georgic_-is active; as Ziser concludes his study of Walden's georgic,

The Walden perceived through georgic eyes proves to be less an object of study than a tool for nourishment; our reading of it less an act of reception than of creation; its purpose, in the here and now, to show the way to a life of creative verbal and physical engagement with the world around us (185).

This ability to convoke new ecological-economic relationships, to call them into being, is the essential strength of the georgic mode, and by adapting it to the new situation of an industrialized landscape, Thoreau becomes both the most influential agrarian writer of the 19 th-century, and perhaps American history. 
IV.

The radical potential of Thoreau's georgic has been productively realized by countless agrarian homesteaders and civil rights activists struggling to live well within industrialized economies. His essential insight of the economic, social, and ecological value of georgic "acquaintance" has inspired and instructed millions to build nonmarket, anti-industrial lives and networks. But unfortunately, Walden's georgic promise has remained marginal within the popular industrial culture, and the literary-studies establishment that has arisen from it. Literary critics and popular readers have instead amplified Walden's pastoral, latching onto Thoreau's command to celebrate environment through sensory attention, yet missing his call to economically engage the nonhuman with the body. This tendency is demonstrated well by the common misquotation of Thoreau as writing "in wilderness is the preservation of the world." That statement suggests him as a precursor to the "wilderness preservation" school of environmentalism, whose problematic underlying pastoralism is well-critiqued by Cronon's "The Trouble with Wilderness.". Yet Thoreau's actual phrase is "in wildness is the preservation of the world" ("W" 239). Thoreau does not call for the preservation of pristine landscapes untouched by human hands, but instead argues for the preservation of the wild within working human economies and polities. As the economist Becker recognizes, Thoreau's suggestion that every community, every town, should protect certain areas of nature and preserve their original wilderness ... is not intended to separate nature from humankind. the idea is rather to create a possibility for a personal encounter[--an acquaintance--]with nature. ... this suggestion reflects Thoreau's epistemological insight that the knowledge of the relation with nature and of the dimensions of nature and human life ... cannot be 
learned merely theoretically. It has to be acquired by personal experience, by individual, personal, and immediate encounter with nature. (240)

Back in "Walking," Thoreau derides "exclusive ... interaction[s] of man on man —a sort of breeding in and in," and calls instead for an interaction of man on nature and nature on man, an interaction that is at once discursive and economic - in other words, georgic (248). On the last page of Our Common Dwelling, Newman rightly extends this insight to today's environmental situation: "if we wish to change our relationship with nature, we must change the way we work within it" (211).

Thoreau's canonization as a pastoral author corresponded with the concomitant acceleration of urbanization and the pastoral ideology of environment. By the close of the frontier at the turn of the 20th-century, land scarcity, the expansion of manufacturing, and the oilfueled industrial agricultural revolution rendered Crèvecoeur 's narrative of a non-market georgic agrarianism less a material possibility than a nostalgic mythology. In 1920, the urban population of the United States exceeded the rural for the first time, and as the century progressed, millions continued to fly from rural to urban spaces. Pastoral discourse — both literary and popularaccordingly increased, as urban residents have no need to consume texts recommending specific economic engagements with environment; they instead export and surrender that engagement to the industrial marketplace.41 Though georgic labor and discourse is still practiced today —and always will be, so long as humans extract energy from environment—it is decidedly marginal, limited to industry, land-grant universities, and those few farmers and gardeners still practicing the craft at human scales.4243 Whereas before industrialization, the georgic was the dominant

41 See Brommell on literary representations of the shift from agrarian to industrial labor. 42 See Ziser for the way land-grant universities facilitated marginalization of georgic discourse. 43 See Sweet on reconstruction georgic. 
cultural mode of apprehending environment, in today's urbanized landscapes, it's now considered "counter-cultural," as the larger population tells themselves pastoral tales. The following chapter on Sandburg will explore in more detail the mechanisms by which the urban-pastoral mind operates in an overwhelmingly industrial and urbanized 20th-century. V.

A Vision, after Emerson and Thoreau, 2014: At the end of the work day once in early October I was picking winter squash with Beth, two miles from the eastern shore of Lake Ontario near Grindstone Creek. It was getting toward dusk, and the sun was obscured by sweeping northern clouds. We worked our way through a two-acre field of squashes buried in waist-high weeds, surrounded by a forest of beech and hickory wearing their fall colors, vibrantly dull in the soft evening light. Like most farm chores we worked in a rhythmdragging, kneeling, searching, severing, plopping, standing and dragging. Over the course of an hour, we likely danced the squash dance a few hundred times. Each time I knelt I leave the world of acres and farmhouses and forests and am immersed in the land of dirt, bugs, squash and weeds. Searching for those squash my hands brush aside a forest of pokeweed, tall, red and sturdy, tassles of choking grasses, stinging nettles, and thistle. Bugs of all sorts prowl and parade, searching with me for sustenance. The squash is withered with mildew, dying in the cold, but it had born many good fruit, sitting firmly, plump on the soil. And the soil! The dirt of that farm is a rich loamy sand, teeming with life - tens of billions of microbes in every square inch. Three months ago that landscape had been obliterated by a tiller: all plants were destroyed, communities of insects were decimated, and the sudden aeration of the soil burned through the micro-biome. Yet now here I kneel amidst a miraculous emergent community of beings infinitely interconnected. Each time I stand I abruptly leave the squash forest and reemerge into the squash 
field, surrounded by trees and sky and barns and my home, up the hill. I live here too-I tend this place that tends me. For an hour I shift between these worlds again and again and again and again. Energy flows from the squash forest through to the fruit I pluck with energy I too take from this soil, alive with the sun, sheltered by the forest, teeming and pulsing with life, emerging again and again and again and again. I hear this pulse and feel it in the squash in my hands. I too pulse in rhythm with the cosmos. 


\section{Sandburg and the Pastoral Logic of Urbanization}

By the close of the frontier at the turn of the 20th-century, Crèvecoeur 's narrative of a widespread non-market georgic agrarianism had faded from material possibility to nostalgic mythology. In 1920, the urban population of the United States exceeded the rural for the first time, and as the century progressed, millions continued to fly from rural to urban spaces. Today, urbanization has accelerated and expanded around the globe, yet both ecocriticism and literary studies has neglected examination of this fundamental and disquietingly recent shift in the human mode of relating to environment. And the few works of urban studies and urban ecocriticism that do exist neglect the key role of pastoral discourse in ideologically underwriting the entwined processes of industrialization and urbanization.

Carl Sandburg's poetry reflects America's urban shift. Written within the spectacularly fast and total industrial transformation of the upper Midwest, and informed by his bohemian ramblings across the country's rural and urban spaces, Sandburg's poetry embodies the way lived economic experience inculcates ecological consciousness. Sandburg's 1922 "The Windy City" shows how the urban metropolis entails and requires a collective pastoral paradigm that "forgets" the ecological basis of the human economy, allowing industry (and some humans) to thrive by forcing other beings to languish. Within the urban-pastoral mindset, the cosmic ecological context of human activity can only be superficially and imaginatively recalled, since the daily labor of city-building precludes direct economic interaction with the nonhuman actants that sustain human life. Yet to the georgic mindset depicted in Sandburg's 1918 "Prairie"—which must daily witness and manage the immediate and physical connection of self to soil, water, and sky—ecology and economy are always already not merely entwined, but one in the same. 
My readings suggest that the ecology/economy facet of the nature/culture divide is so difficult for ecocriticism and environmentalism to disrupt because they are products of the same pastoral-urban mindset that impels industrial progress by precluding intersection of the two spheres. Any ecological vision capable of effecting economic change must reunite economy and ecology in our urban imaginations, but the only method of meaningfully recalling this union is through personal and regular economic interaction with our ecological context. This recognition flows from Thoreau through the Arts and Crafts Movement of Sandburg's day to the New Agrarianism of our own. These movements recognize georgic labor as direct economic activism, which disrupts the environmental and human injustice inherent to industrial economies by reclaiming the production and distribution of the necessaries of life- - food, shelter, clothing, and warmth — for non-industrial community networks.

I.

Today it's easy to forget that human cities are a very rare, recent and novel phenomenon. Even in the last 10,000 years since the first urban settlement at Ur, the global human population remained overwhelmingly rural. World urban population did not rise above $1 \%$ until Roman times, and not above 5\% until 1600. Urbanizations occurred throughout pre-modernity in particularly fertile and temperate regions around the world, yet they were limited in scope geographically and temporally, arising periodically from the broader hunter-gatherer and simple agricultural societies, building a fragile socio-ecological urban matrix for a few decades or centuries, and then disappearing again. Urban historian Paul Barioch writes that before the petroleum-fueled industrial revolution of the $18_{\text {th }}$ and $19_{\text {th }}$ centuries, urban populations were ecologically constrained to approximately $10 \%$ of the national population (501). Thus as a species — and even as a "civilized" one — our cultural and economic heritage is overwhelmingly 
rural. James C. Scott's 2018 Against the Grain explores the extent to which our narratives of early human history thus over-privilege the impact of cities to suggest a steady teleological march toward urban globalization, when in reality urban civilizations are considerably more fleeting, fragile, and socially unequal than rural, subsistence-oriented agrarian societies. It wasn't until the last 300 years that urban populations began a worldwide march toward dominance, and not until 2010 that the world urban population surpassed the rural for the first time. In the long view, the socio-ecological dominance of cities today is a remarkably new social experiment.

This is true even in the brief history of European America. Founded as a resource colony, the bulk of early America's economic activity took place in farms, mines, and forests. The first American urban areas were not centers of consolidated capital and power as in Europe, but acted as peripheral administrative centers tasked with managing the logistics of resource extraction (Glaab and Brown 3). Urban populations remained below 5\% throughout the colonial period, as immigrants pursued wealth in rural spaces through georgic labors. This trend led to the decidedly rural bias in the founding documents and ethos of the United States, which lean heavily on both Jefferson's agrarian vision and the Puritan skepticism of the spiritually corrupt city ethos. Yet when urbanization did occur in the US, it was rapid, perhaps more so than anywhere else on earth (Habenstreit 7). The urban turn was underway in earnest by 1850, the first year that most immigrants eschewed rural work for lives of industrial labor in rapidly expanding northern industrial towns (Habenstreit 8). The exhaustive historical argument over the causes of the Civil War often neglects the important layer of rural vs. urban ethos in the conflicts' great debate over the nation's once and future character. The Union victory accelerated industrialization and urbanization, both in northern cities and the destroyed southern economy. As the Reconstruction era wore on, land scarcity, the resilience of exploitative sharecropping schemes, the expansion of 
urban manufacturing, and the oil-fueled industrialization of agriculture rendered smallhold farming increasingly difficult, and city life increasingly attractive. Today, over $80 \%$ of the US population, and $51 \%$ of the global population, live in urban spaces, and city life has become ubiquitous, less astonishing than banal.

Although this shift from rural to urban life is arguably the most drastic alteration of the human condition in our species' history, literary studies has had surprisingly little to say about it. America's near-exclusively rural beginnings led to a long tradition of anti-urbanism in its arts and letters, from Jefferson through the Transcendentalists, to the Modernists and the academic field of literary studies.44 The editors of the 1981 Literature and the Urban Experience, for instance, write that the collected essays share an "ambiguous attitude toward the city," which though "cautiously hopeful," remains "patent, thorough, and open-eyed" in its "condemnation" $(\mathrm{xv})$. And, as is typical within literary studies, discussion of the city eschews themes of labor, economy, and class, in favor of "power, difference, and identity" (Balshaw and Kennedy 19).45 The intense socio-racial inequality that cities generate is certainly an important topic, and the literary analysis surrounding it has productively explored how "the making of [urban] spaces" is "a social product," and suggested social solutions for urban ills (Balshaw and Kennedy 2). Yet such literary critique of the urban is limited in two important capacities. The first it shares with the general poststructuralist tendency to reduce all phenomena to cultural causes: just as important as asking how human cultural biases structure cities, is questioning how cities generate imaginative bias. The second is a narrow scope: while discussion of specific urban contexts is immediately useful in considering current socio-political problems, it does little to illuminate the

44 See Morton and Lucia White on the anti-urban bias in the American intellectual tradition. See Marsh for the anti-urban ethos of American modernist writers. 45 See Thomas Heise and Carlo Rotella. 
phenomenon of urbanism as a general human phenomenon. To do so, analysis must ironically transcend the city it seeks to understand-because cities are materially dependent on rural extractive areas, no analysis of urban culture is complete without considering the extra-urban origins of its problems.

Ecocriticism has the potential to address both of these gaps, and indeed a duty to, since urbanization is always the process at fault for human degradation of environment. Yet, in Buell's words, attempts at developing a specifically "urban ecocriticism" remain "more earnest than resoundingly successful" (93). The most substantive and sustained treatment of the topic is Christopher Schliephake's 2015 Urban Ecologies. Schliephake probes the "material agency" of city structures to develop "a cultural urban ecology" that "uncovers the imaginative quality inherent in urban space, materiality, and politics and uses this quality to analyze urban environments as ecosystems, in which everything, space and place, matter and meaning, politics and community are inextricably connected" (xliii). While Schliephake's book and other works of "urban ecocriticism" tread productive ground in their explication of urban ecological networks, they tend to reproduce the pastoral tendency of ecocriticism and literary studies more broadly to ignore economic labor, which is a particularly egregious omission while exploring the theme of the "city." 46 Discussion of the extraction, manufacturing, and service industries that build and sustain cities is largely absent from Schlielphake's book and the recent collection edited by Bennett and Teague, and Colin Fisher's Urban Green similarly directs attention away from processes of production and consumption and toward opportunities for escapist recreation "in nature."

46 Gray's Urban Pastoral is the one major literary critical study that links the two topics directly, yet his scope is limited to considering the city as a sort of cosmopolitan version of a pastoral retreat for the New York School. 
A large part of the difficulty in developing a specifically "urban ecocriticism" is that the phenomenon of urbanization does not belong purely or even mostly to city spaces. Cronon illustrates this dynamic in his seminal exploration of Chicago's ecological history, Nature's Metropolis. The book reveals how metropolitan turn transformed the ecological-economy of the entire Midwest, restructuring both rural and urban environments to suit the capitalist goals of maximizing extraction and consumption. Cronon's analysis recognizes that the conceptual dichotomy between country and city is yet one more manifestation of the false divide between nature and culture; cities are merely the administrative core of a capitalist network that, at this point in history, extends its periphery to every corner of the planet. This renders the very term "urban ecocriticism" somewhat redundant, since all of today's targets of ecocritical analysis are, economically at least, "urbanized." When viewed in this light, most all scholarship in the environmental humanities emerges as interested in the urban, though negatively so. Bennett, in arguing for a supposed dearth of "urban ecocriticism" names Wendell Berry and Leslie Marmon Silko in a catalogue of early ecocritics who do not "have much to say about urban culture," despite the fact that cities are for Berry precisely what is "unsettling America," while Silko states that the capitalist drive that creates them "is absolutely irredeemable [and] flat out evil" ("From" 41, Arnold 183-4). Attempts at "urban ecocriticism" at times seem not so much concerned that urban environments have been insufficiently theorized, but that such theories have been insufficiently friendly toward cities.

More useful than the critical category of "urban" may be that of "industrialism," which suggests a condition of enmeshed economic and cultural practices that guide the political and material labor of urbanization across city and rural landscapes. Urban historians often reserve the term "industrial" for the most recent urban revolution of our last 300 years; Bairoch, for instance, 
argues that "where urbanization is concerned, the Industrial Revolution was a break (or acceleration) without precedent since the birth of urbanism" (501).. Yet urbanization the urbanizations of all eras entail and require a massive mobilization of human energy toward a set of similar "civilizing" projects. First, agricultural production must be reoriented from subsistence to the maximization of grain harvests, which can be stored, rationed, and taxed. Grain production is necessarily monocultural, and its maximization requires larger inputs of labor than subsistence farming, hunting, and gathering. Militarization is needed to acquire and maintain labor, and to protect harvests. Then, finally, those harvests can be deployed in the construction and maintenance of the physical infrastructure housing the cultural institutions that constitute a "city." The OED includes several related definitions of "industrial," but all emphasize human labor performed on a "large-scale" ("industrialism, n."). All historical city-building efforts certainly entail that, and indeed perform that labor with the same socially unequal and environmentally disruptive methods that we today associate with "modern" industrialism. The difference with today's variety of industrialism is not in mechanism, but in the scale and amount of labor fossil fuels allow to be deployed toward urbanization. Reserving the descriptor of "industrial" to our "modern" time is yet another "theft of history" that marginalizes the sweeping environmental impact and social innovation of pre-modern civilizations.47 When viewed in this light, industrialism and urbanization emerge as mutually-supportive ecological-economic processes, the former signifying labor and the latter its products.

Val Plumwood examines the imaginative consequences of urban-industrialism in her 2008 "Shadow Places and the Politics of Dwelling," which elaborates on Lewis Mumford's

47 See Goody on the "theft of history," and Jennings for recognition and analysis of plural "globalizations" throughout human history. 
interdisciplinary 1938 observation that "mind takes form in the city; and in turn, urban forms condition mind" (5). Plumwood describes the Western process of "dematerialization," or "becoming more and more out of touch with the material conditions (including ecological conditions) that support or enable our lives" (141). This process is, of course, intrinsic to urbanindustrial life, from the Greeks and Romans to the neoliberal megalopolis, which alike require the import of resources from outside city limits. Yet dematerialization accelerates as economies become more complex and globally interconnected. The supply chain through which a Chicago environmentalist may obtain, say, a belt — with leather sourced from multiple international locations, processed in a sprawling complex located in a southern Asian country yet owned by a European company, with chemical ingredients similarly internationally sourced, which is then distributed, marketed, and sold by other variously located and interconnected corporate entities around the world — is so multifaceted, complex, and unreported as to effectively preclude its apprehension by a typical consumer. Though this Chicagoan may participate in local elections and activism to increase the health of her immediate ecology, the global economy actively prevents her knowledge of, and thus capacity of regard for, the much larger and more environmentally and socially meaningful "economic places ... on earth that support [her] life" and are in turn shaped by her lifestyle (145). Thus, globalization entrenches and accelerates the Western "split between singular, elevated, conscious 'dwelling' places, and the multiple disregarded places of economic and ecological support" that "is one of the most important manifestations of the mind/body split," and I would add, that of culture/nature, the essential divide upon which the pastoral perspective relies (146). Plumwood's analysis reveals the underlying reason ecocriticism and environmentalism stumble when confronted with issues of economy, labor, and urbanization: the movements are themselves phenomena borne of and 
belonging to urban-pastoral life processes, and are thus subject to the entwined material and cultural conditions that enable urban existence by preventing recognition of peripheral ecological context.

Sandburg's poetry suggests that the nature/culture divide is so difficult to transcend because it is inculcated by the subjective human experience of dematerialization intrinsic to urban-industrial work and lifestyles. As Paul Ferlazzo writes, for Sandburg "city and country are not merely settings, but are truly sources of particular states of mind and sets of values" (57). Coal and steel rendered the rapid 19 th-century rise of Chicago unprecedented in human history, and Sandburg's Chicago Poems, his first and most enduring volume of poetry, takes this new urban-industrial cultural ecology as its focus. As John Marsh illustrates, Sandburg viewed urban landscapes through the lens of his early fascination with the Arts and Crafts Movement, using the writings of Ruskin and Morris "to understand and describe contemporary scenes of production ... and distribution" (534). The Arts and Crafts Movement added to Marxist concern for adequate compensation for proletarian work under industrial capitalism an interest in the bodily and mental effects of that labor, which the Movement perceived to be more drudging and alienating than non-industrial modes of production. Preoccupation with such thinking, and his own diverse experiences of both working- and leisure-class labors, leads Sandburg's poetry to focus squarely on the lived experience of the work he describes, from the factory floors of Chicago to the wheat and cornfields of its agricultural hinterlands. Sandburg explores what Thomas Andrews terms "workscapes," or place[s] shaped by the interplay of human labor and natural processes, ... constellations of unruly and ever-unfolding relationships — not simply land, but also air and water, bodies and organisms, as well as the language people use to understand the world, and 
the lens of culture through which they make sense of and act on their surroundings."

Sharing such an expansive conception of work, Sandburg recognizes that the daily maintenance of urban spaces requires human acquiescence to immense ecological violence against human and nonhuman populations alike: "Every day the people sleep and the city dies; / every day the people shake loose, awake and / build the city again" ("Windy City" 123). To maintain the logical "sanity" that builds the metropolis, the urban-industrial mind must pastoralize, psychologically separating its own existence from the ecological crimes which sustain it, and purging questions of economy from the home and public sphere by relegating such discussion to the realm of far-off "experts" beyond the layman's control. An urban-pastoral mind may obtain glimpses of the city's - and itself's - larger ecological context, yet this awareness must remain superficial and fleeting, since the urban human must return to direct participation in normalized economic practices of violent ecological exploitation to remain alive.

II.

Sandburg was in a unique position within his coterie of modernist poets to plumb economic themes because of his particularly diverse work and life experiences. Growing up poor, Sandburg was forced to work a variety of odd jobs, from dishwasher to farmhand and bricklayer, and he served professionally as a solider and newspaperman before settling into the life of a writer. In his youth, Sandburg famously spent months at a time riding the rails through the Midwest, stopping to do odd work in new towns, and cultivating acquaintances with the workers he happened to meet. Though he only acted the hobo as a young man, these cultural travels lasted his whole life, and culminated in his two editions of The American Songbag, which preserve and collect the many folk songs he encountered. Never a college graduate, these 
authentic, laborious interactions with the variety of common Americans served as Sandburg's true poetic education, providing him with the varying perspectives of labor and leisure, urban and rural, that he displayed in his poetry.

Sandburg's poem "The Windy City" demonstrates how urban-industrial life inculcates and requires a pastoral conception of environment. Though its title implies a reprise of his earlier and more famous "Chicago," "Windy City" is longer and broader in scope, presenting an epic depiction of the rise of the city out of its prairie ecology. The poem's opening description of Chicago's inception emphasizes human labor, beginning with "The lean hands of wagon men" selecting the location of the city through the "hitching place[s]" for the "pony express" and "the iron horse" of its hinterlands (1-6). All of the action of the first stanza derives from the "hands" of the initial line, and the second stanza repeats the image, stating that:

the hands of men took hold and tugged,

And the breaths of men went into the junk

And the junk stood up into skyscrapers and asked:

Who am I? Am I a city? And if I am what is my name? (10-14)

The work required by the city's founders does not require them to think, speak, observe, or describe; they merely "point," "pick," "find," "make," and "set up," as directed by distant capital. Their labor requires no direct or personal engagement with raw nonhuman actants as fellow beings, merely externally managed manipulation of commodified animals ("the pony express") and metal ("the iron horse"). The first entity of the poem to express any thought whatsoever is the city itself, which upon its inception immediately questions its existence, though this is only interpretable by the poem's speaker. Whereas the "Early ... red men gave a name to a river, / the place of the skunk, the river of the wild onion smell, / See-caw-go," 
respecting the autonomy of the confluence's prior ecology and naming it as such, the modern city-builders "laugh" at the "junk" they have thoughtlessly imported, responding condescendingly and inaccurately to the city's question, "You? ... we gave you a name, / ... Your name is Chicago" (15-16 emphasis added). The awesome industrial work of "standing" "junk" "up into skyscrapers" that the city builders perform allows them to claim an hubristically outsized role in the creation of the space. They thus incorrectly assume it is they that have the power and right to name their creation, rather than permitting objects to name themselves (as do the Indians).

As the poem moves from Chicago's beginnings to its present, readers receive images of the city notable for their lack of Sandburg's typical attention to nonhumans. This reflects that urban landscapes, especially those of the industrial age of concrete and supermarkets, are defined by an absence of living nonhumans; insects and small mammals become pests, and flora is relegated to carefully contained parks which mimic wilderness. This landscape inculcates a pastoral, anthropocentric humanist ontology necessary for industrial growth that simplifies ecology into two broad categories of moving humans and their inert creations. This simplification enables the "ease" with which human conversation in the city takes place, in a set of stanzas anaphorically privileging the phrase "It is easy" to talk of this or to listen to that (3040). And, as with the city's founders, discussion avoids inhabitants' present economic engagements: schoolchildren learn and "babble" of the city's previous human populations, and though "respectable taxpayers" read of the city's violence and poverty in the newspapers, they do so "easily," such events apparently not affecting their daily activities. The final stanza of the section reads:

It is easy to listen to the haberdasher customers hand each other their 
easy chatter-it is easy to die

alive - to register a living thumbprint and be dead

from the neck up. (33)

This seems to be the speaker's ultimate assessment of the people of Chicago: "dead from the neck up," performing automatic work with hands and lungs yet unable to place that labor in any sort of broader ecological or social context. Stanzas consisting entirely of snippets of overheard conversations reinforce this, as contextual objections to the city's lifestyle are met with both stern rejoinders ("What we want is results, re-sults / And damn the consequences") and urging to ignore such thoughts, to "Hush baby" and to "sh... sh...." (37). Our narrator tells us "'Coo coo, coo coo'"; this lullaby-like command to forget consequences "is one song of Chicago" (37). In one of its two middle stanzas, the poem's narrator asks readers to themselves "remember" that Chicago is "Independent as a hog on ice" (41). This phrase suggests two images: first, that the city's "independence" is more awkward and insecure than its proud residents may admit, and second, that this is so due to the violent industrial innovations upon which Chicago's is built, namely the ability to transport vast quantities of dead animals by rail to growing consumer markets in eastern and European metropoles (41). The ethical ramifications of this industry must remain forgotten, repressed, for its activity to continue.

Readers begin to see the economic conditions that inspire this lullaby in the next stanza of the poem, which presents a typical catalog of urban ills, including "cripples sit[ting] on their stumps" and a mother carrying home the "limp bundle" of her dead son (78). The speaker repeatedly asks the reader to "forgive us" these events: "forgive us if it happens — and happens again — / And happens again" (95). We reach the nadir of the poem and perhaps of Chicago itself with this central stanza: 
Forgive us if we work so hard

And the muscles bunch clumsy on us

And we never know why we work so hard-

If the big houses with little families

And the little houses with big families

Sneer at each other's bars of misunderstanding;

Pity us when we shackle and kill each other

And believe at first we understand

And later say we wonder why. (97-105)

The workers may "believe at first" in the humanist-capitalist logic of industrialism, driven to the city by promises of "better" living through higher wages, yet "later" realize the logic to be insufficient in the simplicity of its humanism, leaving workers beholden to wage slavery and the unfulfilled "wonder[ing]" it inspires. Tragically, these urbanites create their own lack of fulfillment daily through labor that perpetuates a metropolis that excludes nonhuman beings, yet are prevented from realizing it by the urban-pastoral mindset that that very work inculcates.

After this lament, the poem immediately shifts to a cosmic conception of the metropolis in which human concerns fall away. Instead of more human discourse, we abruptly hear "the bevels and the blueprints whisper / ... / Two cool new rivets say, 'Maybe it is morning' / 'God knows'" (114-6). As the speaker transcends the humanist mindset of the urbanites he has described, the nonhuman skyscrapers and other components of the city animistically come alive. We are reminded of what the urbanites "easy chatter" elides, that "The city" is daily labor, a tool chest opened every day, a time clock punched every morning 
I am the woman, the home, the family,

I get breakfast and pay the rent;

I telephone the doctor, the milkman, the undertaker;

I fix the streets

For your first and your last ride-

Come clean with me, come clean or dirty,

I am stone and steel of your sleeping numbers;

I remember all you forget.

I will die as many times

As you make me over again. (100-128)

Although the urban human labor that builds the city, that is the city, forces a forgetting of its ecological context, the city's matter itself stands as a testament to it, "remember[ing] all you [human readers] forget." The speaker provides catalogs of things moving in, around, and beyond the metropolis: "overland trains," "wheat barges," "carload[s] of shorthorns taken off the valleys of Wyoming" (142-5). This wider perspective recalls the metropolis for what it more truly is: not just an blank urban stage for human drama, but a vast new economic system guiding object interactions throughout the West. Though the speaker attributes these great movements of matter and transformations of economy to human actors and human choices (which are by poem's end recognized as occurring constantly, daily, with even the most benign human movements) the poem no longer lingers in the realm of human misery — human morality drops away as descriptions of the wider system emerge. The poem's sense of time also widens, until finally we are treated to a conversation between "the Great Lakes" and "the Grand Prairie": 
... they had little to say to each other,

A whisper or so in a thousand years.

'Some of the cities are big,' said one.

'And some not so big,' said another.

'And sometimes the cities are all gone,'

Said a black knob bluff to a light green sea. (170-5)

But the narrowly concerned human inhabitants of Chicago are unable to recall these cosmic voices, surrounded as they are by human constructions that obscure most of nonhuman nature, and commodify those few nonhuman beings humanity allows itself to witness.

A typical ecocritical interpretation of the poem's final cosmic turn might suggest that more widespread human adoption of the biocentric perspective it demonstrates presents hope for a less troubled metropolitan existence. The cosmic ecological context of human activity that the poem recalls may thus provide the "wonder" lacking in urban lives, and awareness of how individual urban actions connect (via "wheat barges," etc.) to the broader environment may spur environmentalist political or lifestyle changes. Yet this reading is frustrated by the extent to which the poem's humans do not achieve this biocentric awareness; it is precluded by the urban mindset city life necessitates. Only the speaker can access awareness, and only by himself temporarily "forgetting" the human suffering that dominates the poem's first half. Within the urban-pastoral mindset, the cosmic context of human activity can only be superficially, imaginatively, and temporarily recalled, since the daily labor of city-building entails massive ecological violence that must be psychologically repressed for that labor to be performed. One can imagine Sandburg setting down his pen after finishing the poem, rubbing his eyes, and wandering over to the icebox to fix himself a pork sandwich, wondering if the traffic will be light 
enough that he can make it to the newspaper office by a deadline. Though Sandburg as narrator (and his readers) can imagine a more biocentric conception of the metropolis, they cannot conceive (much less enact) an alternate set of economic relations within it that might alleviate the human misery the poem documents precisely because they must exit the poem and return to "normal" city life. This is a problem that ecocriticism (as an urban phenomenon) shares, since the university system is a key actant in the continuing and constant construction of the nowneoliberal global metropolitan complex. Though we in literary studies are permitted to reveal and critique the moral crimes embedded within that economic system, our complicity necessitates a continual repression of the destruction it wreaks that, in ecocriticism, takes the form of an elision of economic discussion.

III.

Sandburg's second volume of poetry, Cornhuskers, widens his attention from Chicago's center to the rural landscapes from which the city originates, and displays a georgic perspective to counter "The Windy City"'s pastoral. Cornhuskers begins with a lengthy poem called "Prairie" which reverses the chronology of "The Windy City," beginning with the geological formation of the prairies themselves, and then moving toward intimate descriptions of contemporary human lives within that scope. This reflects the experience of georgic life as Sandburg documents it throughout Cornhuskers, as human subjects are constantly impressed with direct observation of and interaction with nonhuman ecologies that obviously exist outside the control of mere human hands. The poem's narrator introduces himself thus:

I was born on the prairie and the milk of its wheat, the red of its clover, the eyes of its women, gave me a song and slogan. 
Here the water went down, the icebergs slid with gravel, the gaps and the valleys hissed, and the black loam came, and the yellow sandy loam.

Here between the sheds of the Rocky Mountains and the Appalachians, here now a morning star fixes a fire sign over the timber claims and cow pastures, the corn belt, the cotton belt, the cattle ranches. (1-3)

There are no pastoral illusions here: no sooner is the garden introduced than does the machine incur, as we hear immediately of the "claims," "belts," and "ranches" that power the metropolis. But this activity is presented from the very beginning as occurring under the cosmic "fire sign" of "a morning star," within the context of a total, cosmic ecology in which all interactions are enmeshed and interacting. Early in the poem we receive a pair of descriptions of two trains, one "in the city," "choked and / the pistons hiss and the wheels curse," and one "On the prairie" which "flits on phantom wheels and the sky and / the soil beneath them muffle the pistons and cheer the wheels" (14-5). The industrial metropolis is decidedly present in both urban and rural spaces, though its identical economic activities possess different inflections: the agrarian-georgic landscape mutes its negative consequences, twisting the capitalist mode of production into a less morally ignorant incarnation through its constant reminders of the "soil beneath" metropolitan economic activity.

This reminder takes the form of agricultural labor that reveals to the human subjects of "Prairie" the ecological enmeshment of their economic practices. Whereas industrial urban workscapes rely on the establishment of work-places, which create the appearance of separation between the economic and social spheres of one's life, the agrarian operations of a farm workscape reveal the extent to which all of one's activities, whether consumptive or productive, 
are at once economic and ecological, natural and cultural. The title of Sandburg's collectionCornhuskers-identifies the residents of the prairie entirely with their work, and suggests that it is that labor that engenders their perception of the total cosmic economy. In one of "Prairie"'s central stanzas, we see that "The frost loosens cornhusks. / The sun, the rain, the wind / loosen cornhusks. / The men and women are helpers. / They are all cornhuskers together" (105-9). Unlike "Windy City," in which human labor with the nonhuman world is limited to manipulating dead, commodified objects into products for superfluous human consumption and profit, on Sandburg's "Prairie" all beings move, act, and labor "together," aware of and communicating with each other to get the job done. The work of a farm requires constant and careful attention to and communication with every object within the farm's ecological system. Such labor thus impresses the fact that objects are forged of the same material stuff, bound in the same ecological-economic mesh, and act on us humans as much as we act on them. As Charles Mayer points out, Sandburg "believes that the instincts of the people are at one with the world of natural phenomena"- there is no "other," only the total massed whole of natural movement that is the universe (91).48 Accordingly, the poem's narrator alternates seamlessly and constantly between the omniscient poet himself, dust, the weather or seasons, various human subjects, and often, if not always, the prairie itself. It is at times impossible to discern exactly which of these entities is speaking, suggesting that all of the prairie's beings possess a lively rhetoric that is in the city thought to belong to humanity alone. And it is importantly the agrarian economic work of the prairie that reveals this cosmic biocentric ontology: "handling a pitchfork at hayrack" is "cool prayers to the harvest hands" (8-13).

${ }_{48}$ Other Sandburg critics have reached similar conclusions. Oscar Cargill writes that "Sandburg's love of the land has a mystical quality — a belief that the land will shape people to good ends" (369). 
In contrast to the people of the "Windy City" who look forward to fulfilling their desires, the gaze of Sandburg's agrarian population lingers in a simultaneous past and present, both of which constantly surround their places and guide their actions. "The land and the people hold memories, even among the anthills and / the angleworms, among the toads and woodroachesamong grave- / stone writings rubbed out by the rain - they keep old things that / never grow old" (105-9). Unlike the mindless inhabitants of the city, surrounded exclusively by human beings and the objects they've created, georgic cornhuskers must constantly confront the ghosts of their present situations, the ecology surrounding their economic activity: "The shapes that are gone are here,' said an old man with a cob pipe" (114). Past "shapes" are not only present, but actively recognized and minded by the poem's people, who must consider them constantly while moving through their daily actions. The working rural landscape reveals the constructedness of the human experience of time itself, and inspires the cosmic awareness of "The Windy City"'s conclusion at every turn, allowing all inhabitants the vision which in the city belongs to the poet alone. The necessary remembering of ecological context agricultural labor inculcates within Sandburg's agrarian residents entails too a valuing of one's ecology, impelling an agrarian ethics of careful consumption inspired by and correlated to their economic-ecological situation. This suggests that to maintain a robust and honest conception of one's human existence that unites the realms of self and natural context, human identity and economic-ecology, requires a working lifestyle which is to some extent non-industrial.

IV.

It is important to reiterate that what renders an individual imagination pastoral or georgic is not its placement in either country or city, but its mode of economic engagement with environment. Agricultural and other rural labors can, of course, be industrialized, reduced to a 
godless and genocidal calculation of inputs and outputs managed by the rich and performed by petroleum, machines, and/or exploited human workers. The antebellum plantation model of the American South is one such example, as are the megafarms dominating the agricultural industry today.49 Though the human labor of industrial agriculture can inculcate some of the same effects as the agrarian labor Sandburg describes, those effects are considerably dulled by the mechanical reduction of work processes that industrial economic logic requires. Thus, in the terms of this essay, today's army of agricultural workers of California are today more truly urban and industrial than agrarian laborers; their work is drudging and poorly compensated purely by money, which must be exchanged for the necessaries of life off-farm. Indeed, today oil-fueled technologies have left no corner of the planet non-urban or non-industrialized; even the farthest reaches of the Antarctic are touched by carbon emissions and plastic, and even the remotest agrarian villages are easily accessible via helicopter and satellite, and continue to exist only at the whims of global capitalists. Consequently, some degree of pastoral thinking has become inevitable, spreading its gospel through iPhones and televisions in the inner city and prairie alike.

One small consequence of this pastoralization of American environmental thinking is the canon's relegation of Sandburg to the status of "minor poet." Though Sandburg was the preeminent poetic celebrity of his time, with a popularity ranging from the mass mediums of radio and television to the company of political and cultural elite, literary critics have continually marginalized his work as sociological propaganda masquerading as serious poetry. The high modernists favored by the New Critics and today's literary establishment, by contrast, follow the urban-pastoral tradition of eliding the themes of economic labor that Sandburg places at the heart

49 See Conlogue for an overview of the literary response to the 19 th-century mechanization of agriculture. 
of his poetry, retreating from socio-political realities into abstract, surreal imagism. Impelled by these pastoral trends and encouraged by William Carlos Williams' scathing reviews, by the 1950s most critics considered Sandburg an "author of a handful of sincere but clumsy 1910s lyrics best appreciated by readers uneducated in subtleties of form, technique, and tone" (Reed 189). Evert Villarreal has linked Sandburg's marginalization with the canon's more general neglect of the 20th-century's labor problems; the Norton anthology, for instance, replaces Norris' labor novels with his "Plea for Romantic Fiction" (29). Amy Lowell wrote in 1917 that Sandburg "is a lyric poet, but the lyricist in him has a hard time to make itself heard above the brawling of the market-place" (231). The urban-pastoral paradigm of the 20 th-century was so entrenched, that critics couldn't even recognize the possibility of finding lyricism within the marketplace, as does Sandburg's georgic.

Yet Sandburg was too cagey with his politics for the critical charges of "propaganda" to ring true. Philip Yanella has explored the matter in depth in The Other Carl Sandburg, which contextualizes Sandburg's poetry and varying degrees of socialism in the complex and significant labor struggles of the early 20th-century. Yanella writes that Sandburg's politics transformed from moderate socialism to a deeply radical skepticism of the American project, and finally to the common-man's proponent of "Lincoln liberalism" he became in his old age. Yet Yanella shows that often, these political convictions existed alongside one another, and also "side by side with the Sandburg who was a husband, a father, and an emerging poet trying to make his way in the world of the literary avant-garde" (xxi). Yet at the end of the day, Sandburg was not a politician; he refused repeated entreaties to run for Congress and president, seats his popularity could have won. The only common thread in his politics is support for the common laborer. Sandburg was a writer, a poet, a critic, and a singer, who strove embody the spirit of the common American he 
captured in his art. In this way, Sandburg can help us-critics, teachers, common humans ourselves - to think through how we can fight for change in an era of climate crisis that demands our action, yet seems unsolvable by traditional political activity.

Sandburg's vision of effective social change is ultimately described best not in political terms, but as a celebration and elevation of labor. John Marsh has documented the importance of Sandburg's early fascination with the Arts and Crafts Movement, which privileges he work of independent artisans over industrial mechanization. The movement was inspired by the writings of John Ruskin and William Morris, 19th-century social critics who looked beyond Marx's call for a revolution by labor and for a revolution in labor. Ruskin stepped back from the contemporary concern with working conditions to ask the more foundational question of "what kinds of labour are good for men" (44). He finds his answer in the example of Gothic architecture, the production of which "raises" workers to the status of autonomous craftsmenartists, rather than debasing them into exploited machine-slaves (44). Morris extends this idea to political economy, identifying three basic social classes defined by their relationship to labor: "a class which does not even pretend to work, a class which pretends to work but which produces nothing, and a class which works, but is compelled by the other two classes to do work which is often unproductive" (242). Morris clearly privileges labor which produces the necessaries of life, and diagnoses his contemporary social arrangement as unjust in its compulsion of the lower class to produce not only these necessities for all classes, but also many convenience goods not useful to human survival. Morris' socialist prescription aims, with most leftist thought since, "to get the means of making labour fruitful, the Capital, including the land, machinery, factories, etc., into the hands of the community, to be used for the good of all alike" (298). 
Yet it is important to recall Morris' insistence that any successful redistribution of the means of production requires the "first step" of "abolish[ing] a class of men privileged to shirk their duties as men, thus forcing others to do the work they refuse to do" (294). Though the middle and upper classes today consider producing and consuming discourse to be a useful form of work, perhaps in the "information-" or "service-industry," few farmers, builders, linemen or miners would hesitate to argue that discourse-workers "pretend to work but produce nothing." But regardless of one's definition of "work," it is clear that discourse work does not directly produce the necessaries of life, and to that extent forces others - typically underpaid, exploited, or enslaved human and/or nonhuman others - to perform the labor necessary for the discourseworker to survive. History has borne out the perils of attempting socialization of the means of production while retaining such leisure-class occupations: the resulting "communism" is merely a state capitalism prone to the same faults and weaknesses as the market-based variety. Marxian economists Resnick and Wolff, who conceptualize class status based not on acquisition of power or property but in relationship to surplus labor, explain that a realized communism requires a class structure in which "the producers and appropriators are the same people, whereas the class difference of capitalism is precisely that the appropriators are different people than the producers. The appropriators of the surplus exploit its producers ... insofar as and precisely because they are not also producers themselves" (xi, original emphasis). Morris agrees, suggesting that "all must work according to their ability, and so produce what they must consume...thus at last would true Society be founded. It would rest on equality of condition" (294). Sandburg's agreement with this general philosophy is reflected in his family's commitment to homesteading, and their eventual move to a goat farm in Flat Rock, North Carolina. 
This trajectory of thought is recognizably georgic in its command to reduce consumption of unnecessary goods, and to celebrate and encourage production labor of the sort "good for men," namely the arts and crafts, and gardening most of all. Ruskin and Morris' ideas, and Sandburg's poetry, thus serve as an important link in the georgic tradition, flowing through the arts and crafts movement to the New Agrarianism of the last 30 years.50 The New Agrarianism is effective because it inherently circumvents existing industrial production networks through creation of alternate socio-economic patterns of labor; it does not merely envision an alternate economy, but creates it. Sandburg's poetry lends support to such programs because it demonstrates that intrinsic to georgic labor is the physical and psychological recollection of the connections between the human economy and the cosmic ecology in which it is enmeshed. His celebration of folk songs and rural culture does more than nod to a bygone era, but simultaneously and necessarily reenacts the total network of an ecosystem which recalls its cosmic economy. For, as Raymond Williams argues, the "common idea of a lost rural economy is false"- the rural facets of our cosmic economies are still present, indeed still integral to the functioning of the whole system, and, as Sandburg's Cornhuskers show, it is only by participating in these facets that we can recall, both psychologically and materially, its cosmic scope (300).

50 See Freyfogle for a full account of the New Agrarianism. 


\section{Recalling the Georgic}

If change is to come, then, it will have to come from the outside. it will have to come from the margins.

Wendell Berry, The Unsettling of America

Well, writing that dissertation wasn't labor, but it did take a lot of time. My electrical inspector

The preceding chapters have developed a theory of pastoral and georgic discourse, and argued that the inability of environmentalism to effect meaningful economic change is due to urbanization's inculcation of overly pastoral frames of thought and labor. To create a better relationship between the human community and our ecological neighbors, we must interrogate that nexus both theoretically and materially, which is the realm of georgic discourse. We must Recall the Georgic, recovering the tradition of such thinking and working in our ecologicaleconomies. Yet what, exactly, does Recalling the Georgic entail, and what does it look like in today's climate of hegemonic urbanization and pastoralism? This final chapter will itself utilize the georgic mode to address these questions, offering tangible recommendations for creating more resilient, sustainable, and ethical ecological economies.

My shift from the discourse of literary analysis and ecological theory to economics and agriculture may seem abrupt to some readers. But the georgic's interest in and ability to transition between these spheres is the mode's greatest strength. Despite the modern stereotype, farmers are wide readers. Agriculture is not a narrow practice, but demands expertise in biology and ecology, finance and business, all the building trades, mathematics and engineering, and yes, even storytelling and rhetoric. The georgic canon likewise transcends disciplinary boundaries, engaging a simultaneous cultural and economic discourse. Georgic does not merely represent, but also acts in the world. And its most basic act is its most basic recommendation; Recalling the Georgic means elevating and spreading the practice of agriculture more consistently throughout 
all layers and levels of our social geography, so that georgic discourse becomes once again popular and widespread, existing not outside, but within our living communities.

But before I begin, a note. This dissertation is missing its most important, culminating piece: a full exploration of American Indian ecological-economies, agri-cultures, and forms of literary georgic. Like Thoreau and Crèvecoeur 's farmer James, I recognize that American Indians have often understood much better than white Americans the superiority of selfprovisioning economies to industrial ones. There can be no successful, widespread recollection of georgic in the United States without central attendance to the knowledge of indigenous communities, which — around the world - have proved resilient to the encroachment of pastoral urbanism, and often demonstrate impressive records of long-term, sustainable enmeshment with environment. So my first recommendation is the most important, and one I hope to myself add to this study in revision: examining, elevating, interrogating, and incorporating indigenous ecological knowledge.

I.

Many recent ecocritics and environmentalists have presented conceptions of the interrelatedness of human and nonhuman ecology similar to Burns' natural sympathy, Crèvecoeur 's agrarian community, Thoreau's acquaintance, and Sandburg's cosmic city. Latour's actants, Haraway's naturecultures, and Morton's hyperobjects all seek the same outcome as the georgic canon: an enmeshment of nature and culture. Yet today's environmentalists, both in and out of the academy, are largely unable to envision ways of transferring that biocentric awareness into economic practice. While we have been epistemologically limited by the ecology/economy facet of the nature/culture divide that Sandburg's poetry illustrates, we've been politically distracted by our inheritance of the postmodern tendency to reduce issues of economy to 
questions of culture, and to thus assume that a change in awareness will effect a change in economics. In ecocriticism specifically, we suppose that if we can discursively engender a political ontology aware of nonhuman activity, it will be able to mobilize democratically to enact top-down change to respect and protect that activity through existing institutions. As such, firstwave ecocritics sought to reveal and promote to middle-class urban audiences a wilderness or land ethic, and second wave ecocriticism too seeks to elevate narratives of overlooked matter (in the case of speculative realism) or neocolonial spaces in the global south (in the case of environmental justice writing) with the hope that raising awareness of these extra-urban stories will prime positive environmental action in the lives and voting habits of Western citizens. Ursula Heise's Sense of Place, Sense of Planet presents a sophisticated version of this discourse, positing excessive commitment to fostering change through a local sense of place "a visionary dead end," and advancing instead an ideal of "ecocosmopolitanism" fostering a global "field of reflection" that can allow humanity to address, as a whole, the pressing ecological threats facing our entire species $(21,57)$. This ecocosmopolitan perspective is widespread, and has become the dominant thrust of applied ecocriticism. Graham Huggan, for instance, names it a "politically oriented ecocriticism, which ... has restaked its activist credentials for our neoliberal times," and Greg Garrard asserts that "its most remarkable aspect" resides not in its contribution to literary studies but in its "constructive engagement of ecocritical analysis with environmental policy making" (Lioi).

But Sandburg's poetry reveals the limitations of any application based in consciousnessraising: the economic activities required of urban residents preclude both the sustained imaginative adoption and active implementation of a biocentric ethic by requiring an entwined mental and material acquiescence to anthropocentric industrial logic. This is why, as Anne-Marie 
Brumm notes, Sandburg "had no intention or hope of bringing the lessons he learned in nature back into the city for application" (251). Sandburg realizes that an industrial lifestyle can only permit the kind of superficial and fleeting recognition of the "lesson" of the city's ecological context that concludes "The Windy City." As an urban discourse, eco-cosmopolitanism must linger in the perceptual political realm, because the economic structures that enable it engender a continual return to pastoral frames of thinking that preclude any non-industrial economic engagement. Yet there is an even more practical and insidious problem within ecocosmoplitan consciousness raising: in its absence of an economic arm, it relies for policy making, adoption, and enforcement on the very global political power structures that have created and perpetuate norms of environmental destruction and injustice. As Herman Daly writes, "cosmopolitan globalism weakens national boundaries and the power of national and subnational communities while strengthening the relative power of transnational corporations," which are both unaccountable to electorates and the very actors which have gotten us into this mess in the first place ("Policies" 273). This is not to say that the ecocosmopolitan project is not useful, indeed integral, to enacting broader environmentalist aims; it's just that such discursive activism will not spur change alone. Consciousness-raising can indeed be key to inspiring collective action, but doing that takes more political organizing than merely posting political opinions on the internet. In this sense, environmentalist and ecocritical trends appear to be realizing Michael Branch's 1995 fear that the institutionalization of ecocriticism may "simply reproduce the habits of mind that precipitated the environmental crisis" (98).

To resist this powerful force, we must recognize that our ecological consciousness is inextricably entwined with the neoliberal economic system in which we daily participate (especially from within the academy); to change our consciousness, we must change our 
economics. Val Plumwood concludes in her final published essay that adding a "principle of environmental justice" to environmentalism, which Buell rightly applauds as the most important goal of future ecocriticism, "is a project whose realization ... is basically incompatible with market regimes based on the production of anonymous commodities from remote and unaccountable places" (147). Ecocriticism and environmentalism need to admit that the "principle" undergirding its most important goal is "basically incompatible" with the way nearly all Americans live their daily lives. Wendell Berry writes that "it is ultimately futile to plead and protest and lobby in favor of public ecological responsibility while, in virtually every act of our private lives, we endorse and support an economic system that is by intention, and perhaps by necessity, ecologically irresponsible" (65). We must either linger in hypocrisy, revise those principles, or reach toward integrity by engaging economic practices that are non-industrial and non-anthropocentric. As the georgic perspective reveals, it is only by participating in these economies that we can meaningfully recall and retain a biocentric conception of our ecological context. As Lance Newman recognizes in the closing pages of Our Common Dwelling, "if we wish to change our relationship to nature, we must change the way we work within it" (211). To initiate and sustain these changes, we must ask, answer, and enact the georgic question of how humans should best extract energy from their environment. And, because agriculture is the fundamental and defining activity of any human culture, we must start on the farm.

The American canon of georgic writing broadly suggests that a non-industrial, nonanthropocentric ecological-economy can be found in forms of agrarianism. Though there have been many incarnations and definitions of "agrarianism" across American history, all begin with the position that agriculture is the essential and culturally defining human activity on earth, and thus its practice should be careful, elevated, and widespread. Agrarians use the georgic mode to 
criticize negative agri-cultures, and to promote better ones. What constitutes "better" is, of course, up for debate, and changes according to historical conditions: agrarian thinking has informed movements from the leftist communes of Transcendentalism and the religious and secular back-to-the-landers of the 1970s to the Confederacy, Prairie Populism, and the prepper movement. Yet one economic argument these movements share is a negative reaction to industrialism, which sequesters agriculture away from the communities it supports, and strives for the maximization of production and profit, regardless of the cost to human and environmental health. This anti-industrialism is only increased within today's "new agrarianism," which criticizes the industrial economy not only for its human toll, but for its environmental destruction and injustice. Eric Freyfogle defines the new agrarianism as

a temperament and moral orientation as well as a suite of economic practices, all arising out of the insistent truth that people everywhere are part of the land community, just as dependent as other life on the land's fertility... From this recognition of interconnected life comes an overriding attentiveness to the health of the land. (xiii, xix) This "suite of economic practices" varies among new agrarians, but most promote a sort of bioregionalism featuring locally-oriented community networks of production and consumption, and an attempt to minimize reliance on industrial economic networks.51 Specifically, for any individual or family unit, agrarianism calls to reduce consumption of industrially produced commodities, undertaking home or local production of as many of the necessaries of life as is possible, and locally purchasing what one cannot make to the extent possible. Agrarianism thus exists alongside the common American movements for "simplicity," from the Puritans and

${ }_{51}$ See Lynch et. al., The Bioregional Imagination. 
Thoreau to the Arts and Crafts Movement and today's "minimalism."52 Agrarianism amplifies Ruskin's call for "a determined sacrifice of such convenience, or beauty, or cheapness as is to be got only by the degradation of the workman; and by equally determined demand for the products and results of healthy and ennobling labor" (1285).

So what would agrarianism of the 21 st-century look like? A lot like our communities do now, except with gardens and farms all over the place. The key feature of nonindustrial agricultures is that they admit the supreme importance of local context: ecologically, economically, historically, and socially. Whereas industrial agricultures require specific environmental conditions removed from an urban populace, the diverse polycultures of sustainable agricultural production require dynamic networks of many smaller scale, more locally integrated operations (Jeavons 49). Rather than urban and rural spaces, an agrarian agriculture entails a suburban vision of a human population dispersed over landscapes at rates sustainable by ecosystem context. We might call this a bioregionalist vision, or a "garden city" that elevates practice of food production and consumption within neighborhood spaces.53 This new agrarianism would claim lineage not with the metropoles of Ur and the Nile but with the pre-grain, non-state sedentary communities surrounding them in the Neolithic age, such as Nebelivka in Ukraine, a massive agrarian settlement organized around egalitarian neighborhoods (Gaydarska et. al.).54 The new agrarianism thus breaks too with Jefferson's vision for early America, of vast seas of independently-owned farmsteads stretching across the landscape. The new agrarianism instead turns to models of community ownership, looking to bring farming back into the social fabric by attaching production spaces to institutions, from schools and hospitals to

52 See Shi for an overview of Simple Living in the American tradition. 53 See Northrup and Lipscomb, and Orr. 54 See Scott, Against the Grain. 
workplaces of all sorts. The goal is to integrate agriculture within community structures, and to spread its practice across the population. As this dissertation has argued, participation in extractive labors is also the only way to meaningfully connect nature and culture in our communal environmental consciousness. The first condition of Recalling the Georgic is expanding our working agricultures.

Although many American environmentalists endorse certain agrarian programs, they are often reluctant to fully embrace "agrarianism" as a wider socio-economic ethic. Three reasons are commonly cited. First and foremost, environmentalists are often understandably wary of agrarianism's associations with slavery and white supremacy. Jefferson himself was a notoriously racist slave owner, and although his agrarianism envisioned an egalitarian, emancipated United States, generations of Southerners utilized the rhetoric of agrarianism in making pro-slavery arguments. This association is particularly visible in literary studies, where the Nashville Agrarians of the 1930s produced prolific socio-economic criticism of industrialism that posited a supposedly "agrarian" alternative imbued with not a little Confederate nostalgia.55 Yet it's important to remember that the plantation agriculture of the antebellum South was not actually agrarian at all, but instead extremely industrial, placing profit maximization above care for land and human. As I've argued elsewhere, the pastoral distinction between nature and culture expands in America to include the racist divide between (white) human and (nonwhite) "other."56 The plantation system of the South was economically built on this conceptual divide, and was culturally managed by a leisure class with exceedingly pastoral pretentions, whereas actual agrarian economies in early America were more often found in the less industrial and relatively

55 See Twelve Southeners, I'll Take My Stand. 56 See Horrocks, "Faulkner's Ecologies." 
slaveless upland South and free North. These northern communities more often produced a georgic discourse that recognized the enmeshment of self with all "others," beginning with Crèvecoeur 's rejection of slavery, running through Transcendentalist abolitionism, and to today's New Agrarianism, which often includes explicitly antiracist activism against the rampant otherizing and exploitation of nonwhite laborers in our current industrial food system.57 Critics like Sarah Wald are nonetheless correct in pointing out the whiteness of the New Agrarianism: "with a few notable exceptions, contemporary environmental humanities has neglected to foreground racial meaning as central to either the American pastoral or georgic literatures" (17). Filling this gap will be central to any successful 21 st-century agrarianism, which must draw and build upon the agrarian cultural legacy of all ethnicities.58

Second, today's environmentalists often advance some version of the claim that the agrarian command to alter individual economy masks the "true" perpetrators of the environmental crisis, "the government" or "corporations," who must be pressured politically to realize meaningful environmentalist change. This assertion is often supported in popular discourse with statistics claiming that a wide majority of carbon emissions originate with industrial actors rather than individuals. A quick online search reveals abundant examples of this discourse in popular media, such as a 2017 Guardian op-ed titled "Neoliberalism has conned us into fighting climate change as individuals: Stop obsessing with how personally green you liveand start collectively taking on corporate power" (Lukacs). This position is also the subtext of much ecocritical scholarship, from ecocosmopolitanism's "sense of planet," to ecological theory's articulation of the "transcorporeal" "actor-network" (Heise, Alaimo, Latour). If we imagine our

57 See Fisiko, "Unsettling Ecocriticism." 58 See Leah Penniman, Farming While Black. 
individual selves as "enmeshed" in an infinitely complex ecosystem of living and nonliving "actants," individual agency seems irrelevant—-the only path to large-scale change thus appears to be some alteration of the systemic conditions "enmeshing" us.

The revolutionary potential of these ecological theories are being stymied by pastoral origins, inflections, and interpretations, which present a theoretical flaw and a material one. First, calls for structural rather than individual change rely on a flawed pastoral construction of individual mind as somehow liberated from the broader ecological-economic context in which the body participates. It's often wondered how Jefferson could be an abolitionist and slave-holder simultaneously; we might ask today how one can be an environmentalist yet engage in leisure air-travel simultaneously. New agrarian and farmer Joel Salatin once generated outrage by suggesting that environmentalists aren't truly worried about climate change, because if they were they wouldn't fly. To the pastoral mind, which separates body and mind, his claim is nonsense. But to the georgic perspective, economy is enmeshed in each individual thought and activity, and so the only meaningful expression of environmentalism is through economic action. Too often, arguments for the inefficacy of the individual entail a pastoral pushing-off of economic consideration that permits individuals to continue the hypocrisy of excessive leisure consumption, often purchased with the rewards of meaningless, non-productive "employment." 59 The pastoral paradigm allows the vast class of urbanites engaged in labors either irrelevant or harmful to environmental justice to imagine that their true, meaningful "self" is expressed outside of their work life, in habits of (more or less) virtuous consumption of services and media. So long as our perspective remains pastoral, the problem and its solution will continue to exist beyond our reach, in a realm of "economy" separated from our own oikonomia, controlled by

59 See Graeber, Bullshit Jobs. 
elite political leaders and "experts" that have no incentive, ability, or desire to make egalitarian, environmentalist change.

Arguments for or assuming the inefficacy of individual actions also minimize the material power of the consumer in the late-capitalist system. It's true that consumer choices are endlessly manipulated and perverted by advertising media, but ultimately, in our system, consumers are where the buck stops and starts. Many researchers have suggested that one of the most effective ways to combat climate change would be to reduce meat consumption. This is an objective wholly in control of consumers: if individuals eat less meat and demand alternatives, the market will react. But, of course, this agrarian activism is more difficult than mere theorization or political agitation because it demands actual economic sacrifice. Often it seems that avoiding this necessity is the underlying motivation of those who question agrarian tactics.

But the most significant critique of agrarianism is that it's impossible. Richard White, in a 1995 essay that remains one of ecocriticism's best treatments of labor, provides a succinct example of the typical environmentalist response to the few voices of agrarian reform within its ranks: agrarianism is "a dead end. For such work is always either vanishing or unable to yield a living ... it is not really our work in the world" $(180,179)$. This claim is obviously ridiculous to those who live and work on the 570 million farms in the world, more than 475 millions of which are smaller than five acres, and more than 500 millions of which are family-operated (Lowder et. al.). White's use of the word "our" betrays the first-world, urban-pastoral perspective of the academic environmentalist community, which presumes urbanism as inevitable and normal. This response uses the guise of an economic argument to avoid the economic interrogation agrarianism demands by positing industrial economics as a static natural "real[ity]" to which we must conform, rather than as an emergent network enmeshed with a cultural understanding of 
nature that ecocriticism has potential to shape. A meaningful ecocritical attempt to theorize labor must think beyond current economic realities that enable administrative, informational, and service labor through displaced environmental damage; it must seek with Ruskin "a right understanding, on the part of all classes, of what kind of labor are good for men," and with Jennifer Hamilton "imagine and then enact the type of labors required to build [the] future" it wants to bring into being $(1285,186)$.

The remainder of this chapter will undertake such a reimagination by articulating what agrarian reforms might look like today in the arenas of agriculture, economics, and academia. II.

Agrarianism seeks measures of deindustrialization across all sectors of the economy, but especially within agriculture, which it recognizes as the root of the wider human community. Any attempt to reform our food system requires georgic questions: what is good farming? How can we extract our energy from environment in ways less damaging and disrespectful to our biotic neighbors? It's increasingly clear that we cannot continue exporting these questions to industrial or government "experts," as we have since the land-grant era began. For these giants are controlled and motivated by the interests of distant global capital, which conceptualizes "good farming" as any practice that maximizes yields and return on investment. The resulting devastation has been well-documented.60 Environmentally, industrial agriculture destroys invaluable topsoil by relying on excessive tillage, acreage, and polluting petrochemicals to maintain fertility. And socially, these monocultures rely on armies of drudging, exploited labor. If anything, the terms we use to describe industrial agriculture - unsustainable, destructive, unjust, etc.--insufficiently convey the ethical problems with the practice. From an ecocentric 
perspective, industrial agriculture is truly genocidal, evil, and godless in its treatment of land, plants, and animals. That the products of this system are peddled and consumed without a glance at supermarkets across the country is evidence enough of the entrenchment of the pastoral perspective, which sidesteps these realities with packaging featuring cartoon red barns. The "organic" movement has been a successful attempt to reform the American food system, developing across the 20 th-century to promote more sustainable agricultural practices less reliant on synthetic pesticides and fertilizers. Yet by the 21 st-century, industry and government had coopted this label, turning "organic" from a food revolution to an opaque bureaucratic morass used to upsell food products that remain produced on monocultural, factory-style farms with questionably sourced labor and chemical inputs.61 So long as todays "organic industry" retains its industrial character, it will entail and perpetuate exploitation and misuse of land and labor. This is why positive change must come from outside of industrial actors and the government bodies that support and legitimize them.

Luckily, examples abound of non-industrial agricultures that have sustained human communities for millennia without relying on massive inequalities and environmental destruction. Local, small-scale agrarian food production has indeed been the default agricultural practice of the entirety of human history; state-sponsored industrialized systems (and the environmental havoc they've wreaked) have been the deviation, not the norm (Scott 14). At the turn of the century, land-grant agricultural scientist Franklin Hiram King recognized that increasing mechanization was destroying U.S. topsoil at incredible rates for mediocre yields, and travelled to Southeast Asia to observe the methods farmers there had used to feed vast populations for millennia without depleting topsoil or fertility. His report, Farmers of Forty

61 See Obach, Organic Struggle. 
Centuries, remains a classic of georgic literature, refuting the industrial assertion that nonindustrial methods result in lower yields, and thus cannot feed growing human populations. King describes in great detail how farmers in Korea, Japan, and China maintain complex agricultural systems that lean into the interrelationships of people, plants, and animals to generate efficient, high rates of production in small spaces with non-chemical inputs.

King describes what we today call biointensive, regenerative, or permacultural practices, which have proven effective at restoring soil health and producing high yields nonindustrially. Drawing from premodern, traditional, smallholding agricultural practices, a biointensive approach eschews modern reliance on petroleum-based pesticides and fertilizers and instead focuses primarily on improving soil health and biodiversity (which now-"conventional" practices actually deplete). In the words of Eliot Coleman, biointensive approaches "remove the limiting factors to plant growth ... by generating a balanced soil fertility from within the farm rather than importing it from without. They power the system through nurturing the natural processes of soil fertility, plant growth, and pest management, enabling them to work even better" (2).

Biointensive techniques include cover cropping, crop rotation, direct-barrier insect controls, production and application of compost and animal manures, mulching, companion planting, permanent-raised beds, and deep soil cultivation with minimal surface tillage. Many of the techniques of biointensive agriculture are shared by permaculture, which seeks to develop a sustainable, "permanent agriculture" that minimizes waste and recycles energy by relying on perennial and forest crops.62 By "feeding the soil, not the plant," these practices drastically increase crop production while simultaneously minimizing use of water, fertilizer, and chemical resource inputs, and the pollution associated with their use. John C. Jeavons has shown that

62 See Hemenway, Mollison, and Holmgren. 
biointensive practices "can grow a vegan diet for one person for all year on as little as 371 square meters [4000 square feet or .09th-acre] at reasonably obtainable intermediate-level yields" (66). By contrast, "conventional mechanized chemical and organic agricultural techniques" require about 7,000 square feet to raise a vegan diet and 15,000-30,000 to raise the average diet of a US citizen (67). Biointensive agricultures generate these superior energy-conversion rates by building strong, living soils that can serve as carbon sinks. Since industrial agriculture is the primary driver of climate change, many scientists believe that a turn toward these methods is crucial to ameliorating climate change. The catch with biointensive agriculture is that they replace the industrial power of tractors and chemical fertilizers with human power, but it is in this requirement that they produce an egalitarian effect, spreading the labor of food productionand the georgic perspective it entails - more equitably across society.

It's worth noting that these agricultural practices do not even qualify as "agriculture" to many experts and laymen, who imagine that true "farming" requires vast fields and high yields; permaculture, as it's often argued, cannot feed the world's population. The definition of agriculture as the monocultural cultivation of grains is baked into our historical assumptions: the story goes that agriculture and urbanization arose simultaneously in the Fertile Crescent, and mutually enabled each other. Yet the urban turn of the last 10,000 years was not the first time humans cultivated plants and animals; it's merely the first time they cultivated monocultural grains, which are a crop particularly suitable for urban development, since they can be easily stored, taxed, hoarded, and distributed, and thus require the urban mainstays of walls, protection, slavery, and a leisure-class pastoral ecological consciousness (Scott, Against 130). Yet if we define agriculture more broadly, as merely the cultivation of food crops, farming emerges as an always already fundamental human activity; even the earliest humans employed practices of 
"encouraging" and "protecting" certain food crops (Doolittle 26). The anthropogenic use of fire to trap prey and encourage growth of useful flora and fauna, for example, pre-dates the emergence of homo sapiens by roughly 100,000 years. Early agricultural practices depended on community ability to apprehend, interact with, and preserve as many different ecological actants as possible, and thus encouraged humans to form social structures that, though "varied in detail," were "similar in outline": hunter-gatherers are generally nomadic, egalitarian, and entwine economic labor with what we'd today consider the leisure activities of "ritual, socialization, and artistic expression" (Gowdy 237, xxi). In many ways, agrarianism seeks a reincorporation of traditional knowledge and practices into a modern economy. In contrast to those who see more technology as the solution to the problems more technology has created, agrarianism seeks a more tested and reliable approach, the rediscovery and reincorporation of the traditional knowledge and practices that allowed the Farmers of Forty Centuries.

Yet today's global economic context is not the same as pre-modern southeast Asia; to enact agrarian reforms in the industrialized United States will entail a rethinking of the economy at the largest levels as well as the smallest. For guidance on developing specific policy changes, we can turn toward the field of ecological economics. The mode of ecological economics is georgic, both in its economic aims and concern, and in that it conceptualizes nature and culture as not merely enmeshed in each other, but simultaneous: in the words of Juan Martinez-Alier, "ecological economics studies, at the same time, the physical-biological system and human systems" ("Some Issues" 230). This perspective leads to the field's basic claim, which is obvious to any layman: the human economy is a subset of a wider, global, cosmic ecological system. Yet, incredibly, this fact is received as either irrelevant or anathema by mainstream economists, from the physiocrats through Keynes to today's neoliberals. The mathematical models that constitute 
this mainstream discipline of economics do not and cannot "account" for limits on the total amount of energy that can pass through or be contained within the human economy. In MartinezAlier's words, our economics is one "of long-run growth, the categories of which (national income, investment, consumption, incremental capital/output ratio) paid no attention whatever to physical realities" (Ecological 2). It's not surprising that our economic theory arose without account for the limits to the growth of human economic activity, given that when the physiocrats were writing the human population was low and the most powerful earth-moving tools at our disposal were teams of mules and maybe a stray, inefficient steam engine - in Herman Daly's words, this was an "empty world" (Ecological 52). Yet the massive increase of human power and population unleashed by oil refinement in the 20 th-century has rendered the world "full," and revealed the folly of conceptualizing the human economy as unbound by ecological limits. Thus, since the 1970s, the field of ecological economics challenged this orthodoxy by, first, critiquing the growth paradigm, and second, developing new economic models and theorizations that account more centrally for energy transfers and the socio-economic costs of pollution. This developing inquiry turns many commonplace economic orthodoxies on their head. For instance, whereas conventional economic analysis sees immense increases in agricultural productivity after the industrial turn, "from the point of view of energy analysis ... the productivity of agriculture has not increased, but decreased" (Martinez-Alier Ecological 3).

Ecological economics is a nascent field, and remains a marginal perspective within the discipline of economics, which is not surprising given the immense wealth that the current system is generating for the elite classes which control large-scale economic policy. And it is intellectually diverse, home to a healthy mix of competing perspectives and policy prescriptions. So to claim its precise alignment with the sort of agrarian anti-industrialism this dissertation 
advances would be reductive and false. Yet there is much overlap, especially in its foundational critique of the growth paradigm undergirding industrial development, and in its overriding concern for maintaining environmental health and carrying capacity. And there is shared history between the two patterns of thought. The first 20 th-century giant of ecological economics, Nicholas Georgescu-Roegen, possessed a pro-peasant, "narodnik" political background, and his early articles sought to add energy analysis to the work of the Russian agrarian economist Chayanov, whose analysis of the economic efficiency and social desirability of anti-capitalist, self-provisioning peasant food systems led to his execution by the Soviet state (Martinez-Alier, "Some"). But today, Herman Daly is the ecological economist whose work intersects most with agrarian theory. Most known for his theorization and advocacy of a growth-free and environmentally sustainable "steady-state economy," Daly has provided the authoritative economic voice for anthologies of agrarian writing.63 In the Yale Agrarian Studies Program's 2001 essay collection, Daly provides an essay presenting four clear "Policies for Sustainable Development" that would assist in bringing about large-scale agrarian change. In brief, Daly's policies are to

1. Stop counting the consumption of natural capital as income. ... This biases investment allocation toward projects that deplete natural capital and away from more sustainable projects. Correcting this bias is the logical first step toward a policy of sustainable development. ... 2. Tax labor and income less, and tax resource throughput more, ... either at depletion or pollution, but especially the former. ... As a bumper sticker slogan the idea is 'tax bads, not goods.' ... 3. Maximize the productivity of natural capital in the short run and invest in increasing its supply in the long run. ... 4. Move away from the

63 See Wirzba's The Essential Agrarian Reader. 
ideology of global economic integration by free trade, free capital mobility, and exportled growth—and toward a more nationalist orientation that seeks to develop domestic production for internal markets as the first option, having recourse to international trade only when clearly much more efficient. (268-279).

Daly admits that this closing call for localism is highly controversial; in the humanities, advocating any sort of "nationalism" is often politically incorrect. Proponents of globalism are right to point out the extent to which cultural and economic cosmopolitanism has been the driving force of international peace since the Second World War. Yet this violence has not disappeared, but been transformed into both proxy wars between competing economic blocks, and the devastating "slow violence" of environmental injustice exported from financially-rich countries to poor ones (Nixon). And it is now perpetrated primarily by transnational corporate actors bearing little accountability to either democratic electorates or international governing bodies; they need only answer to shareholders, i.e. the global elite, who demand merely growth and profit. But neither Daly nor any agrarian theory seeks some totally non-cosmopolitan nationalist ecofascism. One beauty of georgic discourse is its recognition of the necessity of compromise, in the home economy and the cosmic one. Agrarianism does not call for "America First," but merely to reclaim power for local communities of neighbors from absent globalist billionaires, through, in Daly's words, "the community rooting of capital for the development of national and local economies" (273).

Yet the most basic agrarian policy is to distribute farmland widely across society: we cannot Recall the Georgic as a species unless agricultural activity is widespread throughout the population. The earliest definition of "agrarian" is, accordingly, "designating a law (lex agraria) for the division of conquered land" in Ancient Rome, and the earliest definition of "agrarianism" 
dates to the 18 th-century, stating "the theory, advocacy, or practice of equal division of land" ("agrarian," "agrarianism,"). Jefferson's agrarianism thus promoted "every person of full age neither owning nor having owned 50 acres of land, shall be entitled to an appropriation of 50 acres in full and absolute dominion" (Papers 350). By this definition alone, Lincoln is perhaps our greatest agrarian president, since his Homestead Act granted 10\% of the total area of the U.S. to homesteaders and small farmers. But, of course, all of these early American land "redistributions" transferred Native lands to whites, often without informed consent. Luckily, race-based land seizures are no longer tenable today, so a new agrarianism must rely on other methods.

Land redistribution and other agrarian goals can be achieved most readily by transferring federal agricultural subsidies and support from large to small operations. Since the 19th-century, federal and state governments, industrialists, and land speculators have been appropriating agrarian rhetoric to transfer power from smallholder farmers to corporate megafarms; the collapse of the small farm economy in the late 1980s was only the culmination of this effort. Today, while politicians sell the farm bill as helping "family farms," in truth these subsidies act as a corporate welfare crony scheme, shifting billions of tax dollars to corporate actors, often to plant nothing at all.64 New agrarianism must reverse this trend, advocating for subsidies to be earmarked for small producers to purchase and develop farmland, and to do so in sustainable, regenerative ways. Indeed, we need to shift all variety of state supports from large operations to small ones. With E.F. Schumacher, we must recognize that Small is Beautiful, and rework our institutions to be "human scaled," comprised by and serving the well-being of actual individuals

64 See Imhoff and Badaracco, The Farm Bill. 
rather than giant corporate or government bureaucracies. And we should reorganize these appropriately scaled groups into new forms emphasizing democratic, community ownership.65

Agrarianism and ecological economics ask us to rethink our most basic assumptions about our home economies and finances, and to reorient our most basic life and family goals from that of linear growth and accumulation to rhythmic sustainability and non-financial wealth. Many critics of agrarianism correctly point out that there is no money in small farming. But the fact that agrarian labors bear little profit indicates their inherent resistance to the industrialcapitalist logic of modern urbanization, and is thus precisely the reason they are worth enacting. The idea of profit as economic necessity is an industrial idea we must discard, for small-scale agricultural and other production activities are, of course, economically realistic; they have for millennia, and continue to be, performed every day across the world. It is true that agrarian labor may not produce the sort of hyper-consumptive, industrial style of life to which we have become accustomed; but this is also its key virtue, because the current growth-oriented conception of economy we now typically use to measure which labors are worth performing is delusional, and is quickly running up against the constraints of our global ecology. Regenerative agricultures are worth pursuing precisely because they are not oriented toward commodification and profit, but instead provisioning community.

The humanities, as well as academia and the education system more broadly, also have key roles to pay in any agrarian turn. In the humanities, we must move past deconstruction and critique, and reconceptualize our scholarship as an act of composition. Bruno Latour has rigorously demonstrated that "critique has run out of steam" "because it was predicated on the discovery of a true world of realities lying behind a veil of appearances" ("Compositionist" 474).

65 See Wolff, Democracy at Work. 
"With critique, you may debunk, reveal, unveil, but only as long as you establish, through this process of creative destruction, a privileged access to the world of reality behind the veils of appearances" ("Compositionist" 475). The problem with this process is twofold: first, it is iconoclastic, trapped in an endless cycle of construction and destruction, and second, it relies on the ontologically suspect existence of "facts" (reality) and "fetishes" (social constructions); in other words, a separation between "construction and truth," the goal of critique being distinguish the two (Latour, Modern). Yet the problem with this is that the two worlds are implicated in each other; ultimately neither exist at all—all phenomena are in Latour's terms, "factishes." Rather than critique, Latour suggests we attempt instead to "compose," finding "the wisdom of the factishes" by "draw[ing] attention away from the irrelevant difference between what is constructed and what is not constructed, toward the crucial difference between what is well or badly composed" ("Compositionist" 747).

In the terms of this dissertation, critique operates in the pastoral mode, whereas composition operates in the georgic. Pastoral and critique both construct and rely on entwined dichotomies between reality and construction, nature and culture. Pastoral, in its "complex" form, is itself usefully critical, displaying these oppositions in order to reveal simultaneously their interpenetration. Yet it is also limited by its conventional elision of human economy: to oppose nature and culture, pastoral must sidestep the locus of their interconnection, and thus cannot theorize new modes of human being. In Latour's words, "what performs a critique cannot also compose" ("Compositionist" 475). Georgic is not interested in the utopian ideals of pastoral, but with generating outcomes that are better than the current situation. Latour closes his plea for compositionism by writing that 
Everything happens as if the human race were on the move again, expelled from one utopia, that of economics, and in search of another, that of ecology. Two different interpretations of one precious little root, eikos, the first being a dystopia and the second a promise that as yet no one knows how to fulfill. How can a livable and breathable "home" be built for those errant masses? That is the only question worth raising in this Compositionist Manifesto. ("Compositionist" 488)

This question of oikos is ecological-economic: is the georgic question. Raymond Williams himself makes a georgic turn at the end of The Country and the City, gaining from his seminal discussion of pastoral the recognition that criticism, at its best, is not a deconstructive and iconoclastic "practice" but a "creative" one, "not casting off ideology or learning phrases about it, but confronting a hegemony in the fibres of the self and in the hard practical substance of effective and continuing relationships" (Marxism 212). In Lance Newman's words, the job of criticism "is to make available, as a living tradition from which we can learn in the present, the history of revolutionary consciousness in creative, cultural practice" (208). To effect broad and meaningful change, ecocriticism must examine stories and ideas that exist at the working nexus of nature and culture, plumbing them for insights into how we can create, in our own present existences, modes and systems of labor that will offer, instead of anxiety, alienation, and injustice, sustainable ecological attachment.

Accordingly, humanities scholarship, and indeed research across all disciplines, needs to increase focus on the georgic both as an object of study and as a mode of performing scholarship. At its most simple level, this means attending centrally to issues of economics. The overwhelming focus on theorizing race and gender of the last 30 years has been extremely useful, but we need to add concern for the ways these identity categories are enmeshed in 
ecological-economic context, and how the lives of exploited populations might be materially improved. One of the benefits of performing scholarship in the georgic mode is its inherent interdisciplinarity; such work has the potential to perform analysis that builds together insights from the hard and social sciences, with an overriding concern for their ecological-economic consequences. And the humanities should not be bullied into thinking that they are somehow unqualified for economic discussion. As critics like Daly have demonstrated, the focus of the economic discipline is too narrow both in terms of methodology and its fields of concern; a central way that the hegemony of the discipline is maintained is in denying the status of "economist" to anyone who disagrees (Ecological xiii). But economy is too important a critical category for the humanities to cede; indeed, it is a function primary and universal to the human condition. We are all economists! We in the humanities can utilize the same critical techniques that we have levelled at race and gender to develop an expanded conception of economy that can add material weight to our cultural recommendations. In literary studies, we can begin by expanding the New Economic Criticism, which recognizes a structural homology between systems of discourse and economy, and by contributing to the development of ecological economics.66 The first basic task of the discipline is to develop measures beyond GNP to apprehend the "well-being" of communities, which is one of the primary categories addressed by literary studies and philosophy.

As humanities make an economic turn, the first location to theorize and force change is within the structures of the academy that scholars know best. This is accordant with the georgic and agrarian command to make change first within the community in which one is already enmeshed. First, the obvious and well-documented problematic labor practices of the academy

66 See Heinzelman and Goux. 
must be tackled. That legions of tenured professors can so loudly espouse concern for "social justice" while benefiting from this exploitation is evidence enough of the labor-eliding pastoral paradigm's hegemony in academic discourse. Resources need to be reallocated from university administration - the ultimate class of those who, in Morris' words, "pretend to work and yet produce nothing" — and full-time faculty to provide a living wage for all instructors, research workers, and staff (294). Second, academia and the environmental humanities in particular are in strong position to develop, manage, and expand institutional farms. Many colleges already possess such programs, though few attract the community buy-in to reach their full potential. Building that support is the most important and revolutionary outcome ecocriticism has the power to affect. A school farm can be constructed right now, and from within our current institutional contexts. Beyond unleashing potential for myriad interdisciplinary educational programs and providing valuable instruction in the agrarian arts tragically absent from most curricula, a school farm establishes a real and consequential economic structure that inculcates ecological consciousness and materially and immediately prevents socioenvironmental destruction and injustice.

Agrarian reforms are so powerful and wide-reaching precisely because of the centrality of agriculture to any human community: the way we produce, distribute, and consume our food determines our culture, and a shift from industrial to biointensive agricultures will be as profound as the early modern shift from feudal communes to industrial improvements, and from hunter-gathering to monocultural grain cultivation. As it's often said, "permaculture is a revolution disguised as gardening." This slogan conveys the best attribute of agrarian reform: it doesn't entail burning anything down or overthrowing political systems, or waiting for others to do that for us. Its most basic and effective command is simply to grow plants, and let the rest 
follow. Spreading farms and gardens across the landscape enacts change slowly and productively by weakening harmful institutions and buttressing useful ones. This effect is the strength and beauty of agrarian economics. They work peacefully by rewiring our ecological consciousness through labors that are meaningful not only to practitioners, but also to the global ecological community, by performing the necessary work of life with deliberation, care, and justice. III.

Examples abound of individuals, families and communities doing economically successful agrarian work around the U.S. and the world. Fortunately, the local community and home production of many of life's necessities is, if not easy, entirely possible for nearly any family or individual to accomplish part-time if undertaken with sufficient thoughtfulness, preparation, and determination. Shannon Hayes' book Radical Homemakers documents dozens of families who have in various ways and to varying degrees reclaimed their economic existences from the direction of global capital. They might include grow gardens, forage for food, fish or hunt, purchase and preserve local harvests, raise chickens or goats, sew and knit clothes, teach in community or homeschool groups, build furniture, manage neighborhood orchards, cut firewood and lumber, construct their own shelters, make tree syrup, and much more. All of these labors cultivate georgic Thoreauvian "acquaintance" with our nonhuman neighbors, their practice entailing a bodily recollection of the ecological genesis of the craft, and inculcating a consciousness of the enmeshment of nature and culture. The list of such now"radical" homemaking practices is endless, and supports a vibrant "why and how-to" literature in print and online. Though some of these agrarians live on strictly leftist or conservative communes, most are just moderate citizens who merely adjust their lifestyles to rely less on the global industrial system and more on the labors of themselves and their neighbors. In Wolff and 
Resnick's terms, their family and community structures strive to produce as much as possible of the surplus they must appropriate to live healthily and happily. It is impossible as a 21 st-century world citizen to fully escape the ideological and economic clutches of industrial capitalism, the agrarian command is luckily not an extreme one. It does not seek an impractical, immediate, and wholesale social reordering, but it does ask each of us to start that journey. And doing so is not difficult; with little effort, one can achieve impressive degrees of escape and resistance from industrialism by practicing agrarian economics at any scale.

Travelling has taught me that there is agrarianism everywhere. But it is often unassuming, quiet, and modest, working carefully and deliberately in the margins of our dominant ecological-economic system. Below I will reveal seven agrarian individuals and families across the U.S. successfully Recalling the Georgic in their own lives and communities. I selected these examples because they're communities I've encountered in my own life; a visit to any county in America will reveal hundreds - maybe thousands - more. And I share these examples with three intentions: to explicate what I mean when I ask us to Recall the Georgic, to provide evidence that doing so is readily achievable in today's socio-economy, and to inspire readers to follow our example.

Grindstone Farm sits three miles from the shore of Lake Ontario in Oswego County, New York. The area boomed in the 19th-century; as factories and factory-towns sprang up in Pulaski, Fulton, and Oswego, the agricultural sector turned from self-provisioning to profit, increasing yields of dairy and grain for urban export. Dick DeGraff's family ran these farms through to the mid-20th-century, when globalization brought the rust of deindustrialization to the county, rendering cash-crop farming in the brutal Oswego County winters no longer profitable. When Dick grew up in the 70s, he wanted to farm, so he innovated, becoming one of the first organic 
producers in the state, selling vegetables, blueberries, and asparagus through a CSA, farmers markets, on-farm sales, and to the Park Slope Co-op in Brooklyn. When I worked at Grindstone around 2010, the farm employed 5-10 people, depending on the season, and paid well, despite the farm's perennial financial problems. It seemed to me that Dick was always more interested in paying people to farm than turning a profit. The most remarkable thing about the place is its community. In the back blueberry field in the woods, Dick maintains a large pond surrounded by a pavilion, a stage, and two cabins. Throughout the summer, especially in the evenings, various members of the farm's crew, family, and friends would gather at the pond to swim, cook, eat, drink, dance, and talk over the farm's work. The pond wasn't a leisure space—it was literally surrounded by a working blueberry field, the infrastructure was under a constant state of rerepair, and the farm was always the primary topic of conversation. I've never been a part of a community that was less formal, or more open. I think the reason for this was our working relationship with each other.

I have family in Oswego County, and have visited there all my life. Growing up, it was rare to see any significant farming activity going on. Most fields sat empty, cut for hay if for anything, with a few patches of field corn here and there. As the industrial economy left, a small tourist trade around the Lake and rivers arose, but, plagued by high property taxes, it was never able to bring the same kind of financial prosperity to the county's residents. Property values plummeted, and poverty increased. This situation left the area ripe for Amish colonization. It started with one or two families moving in from Ohio, attracted by the cheapness and quality of the land - because of the long, harsh winters, the area's rich, glacially-deposited loam was not able to be as ravaged by the industrial techniques of the preceding centuries. At first these new arrivals were viewed with skepticism by the area's "English," as the Amish call them. Unwilling 
to apply for credit, Amish farms did not look wealthy, clean, or productive at first. But slowly, farms started developing, and as new families arrived, a strong and mutually supportive community emerged. Today, Amish farms are everywhere, growing vegetables, hay, horses, grains, and dairy; they've also branched into family-scale manufacturing, making and selling baskets and a lot of lumber. The Amish and "English" communities have also begun to integrate, and even grow together; there seems to be a lot more activity going on non-Amish farms these days too, and examples abound of cooperative manufacturing and selling arrangements. Though my mother is friendly with many families, I've only visited one Amish farm myself, picking up eggs for Grindstone to distribute through their CSA. Dick told me to take a look in the barn, which was built overtop of a small creek. The temperature dropped ten degrees as I stepped out of the hot sun and into the damp, stone ground floor. Several girls, ranging in age from 5 to 20 were set up in the corner, doing some sort of menial handitask. I heard a rushing noise, and looked left to find a six-foot waterwheel spinning along with the creek. Upstairs the family had a shop setup, with band saws and drill presses, all running off power from the stream.

Very little farming goes on where I grew up in suburban Maryland, but there is one operation in Gaithersburg, Red Wiggler Community Farm, with an outsize community impact. Once a gentleman's horse farm, the land was gifted to the county in the mid-20th-century, and then sat for decades as an underutilized recreational green space. In 1996, Woody Woodroof convinced the county to lease him the space to develop the nonprofit Red Wiggler Community Farm, a "sustainable farm where people with and without developmental disabilities come together to work, learn, and grow healthy food." The farm employs dozens of people with disabilities each season to grow, market, and sell vegetables through a CSA and market garden. Red Wiggler further serves as a community food hub, bringing together individuals from around 
the county to work and learn about food and farming through educational and outreach programming, and many volunteer opportunities.

One of my undergraduate English professors, Kate Chandler, was a great lover of compost. It was her favorite matter and metaphor-she made it, used it, wrote about it, and taught us all about it. The first year I attended St. Mary's College, in 2007, Kate decided to make the georgic turn in her teaching, to stop just assigning us readings about compost, but to assign us to make some ourselves. So she and my friend Nathan convinced the college to lend them a two-acre plot of land on the edge of campus to start the "Campus Community Farm." At first it was just a garden space, where a student club could come to play in the dirt, make mistakes, and grow some food. But it slowly grew, adding a greenhouse, rabbit hutch, perennial beds, chicken coop, and, of course, a composting system. Today the farm grows substantial amounts of produce for the school cafeteria, serves as an outdoor classroom for courses across disciplines, and serves as a meeting and working spot for students, faculty, staff, neighbors, and church communities. Kate died of cancer in 2016, and we renamed the garden the "Kate Chandler Campus Farm," or the "Kate Farm," for short. Her georgic turn, late in life, entailed the creation not only of that two acre garden, but dozens of small farms across the country started by college students who first got their hands dirty turning her compost pile.

Doug and Cathy grew up on different sides of Chicago. They met as young people in the 1960 's and joined others of their generation moving "back-to-the-land," ending up in the valley of the Little Mulberry River in the Ozark Mountains of Johnson County, Arkansas. They and others formed a leftist commune seeking to raise its own food, shelter, and clothing from the surrounding forests, and to start a residential school for at-risk urban youth. By the 1980s the commune had broken up, falling victim to some of the same problems as Hawthorne's 
Blithedale. But Doug and Cathy had fallen in love with the area, and bought 20 acres a few miles down the river. Doug started a construction business, and they raised a family and a homestead using permaculture design principles. Today their half-acre garden of perennials and forest crops is extremely productive, and they're able to produce the vast majority of their food from their plot. One of their daughters built a cabin up the hill, and will continue to steward that land for the rest of her life.

Matt Pefferman grew up in New Martinsville, West Virginia, a small manufacturing town on the shores of the Ohio River. That whole area was hit hard by outsourcing and foreign competition in the latter half of the 20th-century. Nobody's job was secure; even if the bosses and owners liked you and didn't want to lay you off, at the end of the day they were at the mercy of the market and had to answer to the bottom line. Living at the mercy of these companies, Matt grew up listening to his grandparents tell stories of their childhoods during the Great Depression. None of them had much money, but his grandparents who lived in the city went hungry, while grandfather who grew up in the country still had plenty of food. He was raised by his grandparents on a subsistence farm, and life went on as normal. At a young age, Matt realized it was more important to have a reliable food supply than a lot of money, and that he'd "rather be like my hillbilly grandpa, no matter what society said." Now entering his thirties, Matt is rebuilding his grandfather's deserted homestead out of town. He and his dad are keeping bees and tapping maple trees, and he's slowly building fence to expand his garden and keep animals.

When I entered the West Virginia University $\mathrm{PhD}$ program and started writing this dissertation, my wife and I bought five acres of land with a run-down cabin outside of town. We got some chickens and started a garden, which totally failed the first summer. But we kept growing, and in the second year tapped some maple trees and started selling at a local farmers 
market. Today we've established a highly productive $1 / 3$ rd-acre market garden, and tap 200 red maples each year. I spend about 30 weeks in the summer tending the garden and selling produce, and 15-20 in the shoulder seasons. If I weren't selling, I could grow enough staple crops to feed us all year with significantly less effort. The garden has remained profitable every year of operation, both financially, and in turning more significant rewards of good food, good living, and ecological acquaintance. 


\section{Bibliography}

"agrarian, adj. and n." OED Online, Oxford University Press, December 2019, www.oed.com/view/Entry/4137. Accessed 16 February 2020.

"agrarianism, n." OED Online, Oxford University Press, December 2019, www.oed.com/view/Entry/4138. Accessed 16 February 2020.

Alcott, Bronson. The Journals of Bronson Alcott. Boston: Little Brown and Company, 1938.

Alpers, Paul. What is Pastoral? Chicago: University of Chicago Press, 1996.

Anderson, D. R. "Wild Farming: Thoreau and Agrarian Life." in The Agrarian Roots of Pragmatism. ed. Paul Thompson and T. C. Hilde. Nashville, Tn: Vanderbilt University Press, 2000. 153-63.

Andrews, Thomas. Killing for Coal. Cambridge, Ma: Harvard University Press, 2008.

Appleby, Joyce. "Commercial Farming and the 'Agrarian Myth' in the Early Republic." Journal of American History. 68 (1982): 833-49.

Bairoch, Paul. Cities and Economic Development: From the Dawn of History to the Present. Chicago Il: University of Chicago Press, 1988.

Balshaw, Maria and Liam Kennedy, eds. Urban Space and Representation. London: Sterling Press, 2000.

Barrell, John. Poetry, Language, and Politics. Manchester: Manchester University Press, 1988.

Bate, Jonathan. Romantic Ecology. London: Routledge, 1991.

Becker, Christian. "Thoreau's economic philosophy." Euro. J. History of Economic Thought. 15.2 (2008): 211-236.

Bennett, Michael and David Teague, eds. The Nature of Cities: Ecocriticism and Urban Environments. Tucson: University of Arizona Press, 1999.

Bennett, Michael. "From Wide Open Spaces to Metropolitan Places: The Urban Challenge to Ecocriticism." ISLE. 8.1 (2001): 31-52.

Bentman, Raymond. "Robert Burns' Declining Fame." Studies in Romanticism. 11.3 (1972): 207-224.

Berry, Wendell. The Unsettling of America. Berkeley, CA: Counterpoint, 1977. 
- "The Whole Horse." In The New Agrarianism: Land, Culture, and the Community of Life. Ed. Eric Freyfogle. Washington DC: Island Press, 2001. 63-80.

Birch, Thomas and Fred Metting. "The Economic Design of Walden." The New England Quarterly. 65.4 (1992): 587-602.

Branch, Michael. "Ecocriticism: Surviving Institutionalization in the Academic Environment." ISLE. 2.1 (1994): 91-99.

Bromell, Nicholas. By the Sweat of the Brow: Literature and Labor in Antebellum America. Chicago, Il: University of Chicago Press, 1993.

Brumm, Anne-Marie. "The Cycle of Life: Motifs in the Chicago Poems of Carl Sandburg." Zeitschrift fur Anglistik und Amerikanistik 31.3 (1983): 237-355.

Buell, Lawrence. "Ecocriticism: Some Emerging Trends." Qui Parle. 19.2 (2011): 87-115.

—. Emerson. Cambridge, Ma: Belknap Press, 2004.

—. The Environmental Imagination. Cambridge, Ma: Belknap Press, 1996.

Burns, Robert. Selected Poems and Songs. Oxford: Oxford University Press, 2013.

- Letters of Robert Burns. Oxford: Clarendon Press, 1985.

Bushman, Richard. The American Farmer in the Eighteenth Century: A Social and Cultural History. New Haven: Yale University Press, 2018.

Carruthers, Gerard. Robert Burns. Liverpool: Liverpool University Press, 2010.

Cargill, Oscar. "Carl Sandburg: Crusader and Mystic." College English. 11.7 (1950): 365-372.

Cavell, Stanley. The Senses of Walden. New York City, Ny: Viking Press, 1972.

Chayanov, Alexander. The Theory of the Peasant Economy. Madison: University of Wisconsin Press, 1986.

Clancy, Jonathan. "Elbert Hubbard, Transcendentalism and the Arts and Crafts Movement in America." The Journal of Modern Craft. 2 (2009): 143-160.

Coleman, Eliot. The New Organic Grower. White River Junction, VT: Chelsea Green, 1995.

Conlogue, William. Working the Garden. Chapel Hill, Nc: University of North Carolina Press, 2001. 
Crèvecoeur, J. Hector St. Jean de. Letters from an American Farmer. Oxford: Oxford University Press, 1998.

—. Sketches of Eighteenth Century America. New Haven: Yale University Press. 1925.

Cronon, William. Changes in the Land: Indians, Colonists, and the Ecology of New England. New York: Hill and Wang, 2003.

- Nature's Metropolis: Chicago and the Great West. New York: Norton, 1991.

—. "The Trouble with Wilderness, or Getting Back to the Wrong Nature." in Uncommon Ground: Rethinking the Human Place in Nature. Ed. William Cronon. New York, Ny: W.W. Norton \& Co., 1995. 69-90.

Daly, Herman. Ecological Economics and the Ecology of Economics. Cheltenham: Edward Elgar, 1999.

.Policies for Sustainable Development." in Agrarian Studies: Synthetic Work at the Cutting Edge. ed. James C. Scott and Nina Bhatt. New Haven, Ct: Yale University Press, 2001. 264-282.

Davidson, Adam. The Passion Economy: The New Rules for Thriving in the Twenty-First Century. New York: Knopf, 2020.

Delano, Sterling. "Thoreau's Visit to Brook Farm." Thoreau Society Bulletin. 221/222 (Fall 1997/Spring 1998): 1-2.

Devine, T.M. The Transformation of Rural Scotland: Social Change and the Agrarian Economy, 1660-1815. Edinburgh: Edinburgh University Press, 1994.

Dictionary of the Scots Language. University of Glasgow.

Dillman, Jefferson. Colonizing Paradise: Landscape and Empire in the British West Indies. Tuscaloosa: University of Alabama Press, 2015.

Doolittle, William. Cultivated Landscapes of Native North America. New York: Oxford University Press, 2000.

Emerson, Ralph Waldo. "Farming." In The Collected Works of Ralph Waldo Emerson, Volume VII. Cambridge, Ma: Harvard University Press, 2007.

—. "Man the Reformer" in The Collected Works of Ralph Waldo Emerson, Volume I. Cambridge, Ma: Harvard University Press, 1971.

—. "Musketaquid." In The Complete Works of Ralph Waldo Emerson, Volume 9. Boston, Ma: Houghton, Mifflin and Company, 1904. 
—. "Nature." The Collected Works of Ralph Waldo Emerson, Volume I. Cambridge, Ma: Harvard University Press, 1971.

- The Selected Letters of Ralph Waldo Emerson. New York, Ny: Columbia University Press, 1997.

Feingold, Richard. Nature and Society: Late Eighteenth-Century Uses of the Pastoral and Georgic. New Brunswick: Rutgers University Press, 1978.

Ferlazzo, Paul J "The Urban-Rural Vision of Carl Sandburg." Midamerica. 1.1 (1974): 53-57

Fisher, Colin. Urban Green. Chapel Hill: North Carolina University Press, 2015.

Fiskio, Janet. "Unsettling Ecocriticism: Rethinking Agrarianism, Place, and Citizenship." American Literature. 84.2 (2012): 301-325.

Francis, Richard. Transcendental Utopias: Individual and Community at Brook Farm, Fruitlands, and Walden. Ithaca, Ny: Cornell University Press, 1997.

Freyfogle, Eric, ed.. The New Agrarianism. Washington: Island Press, 2001.

Foster, John Bellamy. Marx's Ecology. New York: Monthly Review Press, 2000.

Garrard, Greg. Ecocriticism. New York: Routledge, 2012.

—_. "Radical Pastoral?" Studies in Romanticism. 35.3 (1996): 449-465.

Gaydarksa, Bisserka, Marco Nebbia and John Chapman. "Trypilla Megasites in Context: Independent Urban Development in Chalcolithic Eastern Europe." Cambridge Archaeological Journal. 30.1 (2020): 97-121.

Gifford, Terry. Pastoral. New York: Routledge, 1999.

_ . "Pastoral, Anti-Pastoral, and Post-Pastoral." Louise Westling, ed. The Cambridge Companion to Literature and Environment. Cambridge: Cambridge University Press, 2014.

Gilmore, Michael. American Romanticism and the Marketplace. Chicago: University of Chicago Press, 1985.

—_ "Walden and the 'Curse of Trade'." in Henry David Thoreau. Ed. Harold Bloom. New York, Ny: Chelsea House, 1987. 223-238.

Glaab, Charles and A. Theodore Brown, A History of Urban America. New York: Macmillan, 1976. 
Goody, Jack. The Theft of History. Cambridge: Cambridge University Press, 2006.

Goux, Jean-Joseph. Symbolic Economies. Ithaca, NY: Cornell University Press, 1990.

Gowdy, John, ed. Limited Wants, Unlimited Means. Washington DC: Island Press, 1998.

Grabo, Norman. "Crèvecoeur's American: Beginning the World Anew." The William and Mary Quarterly. 48.2 (1991): 159-172.

Graeber, David. Bullshit Jobs: A Theory. New York Ny: Simon and Schuster, 2018.

Gray, Timothy. Urban pastoral: natural currents in the New School. Iowa City: University of Iowa Press, 2010. need to make footnote

Gross, Robert. "The Great Bean-Field Hoax: Thoreau and the Agricultural Reformers." Virginia Quarterly Review. 61.3 (1985)

—. "'The Most Estimable Place in All the World': A Debate on Progress in NineteenthCentury Concord." Studies in the American Renaissance. (1978): 1-15.

Habenstreit, Barbara. The Making of Urban America. New York: Messner, 1970.

Hamilton, Jennifer. "Labour." Environmental Humanities. 6 (2015): 183-186.

Hammerschmidt, Soren. "Ramsay, Fergusson, Thomson, Davidson and Urban Poetry." in The Edinburgh History of Scottish Literature. Edinburgh: Edinburgh University Press, 2007.

Harkin, Michael and David Lewis, eds. Native Americans and the Environment. Lincoln: University of Nebraska Press, 2007.

Harraway, Donna. The Companion Species Manifesto. Chicago: University of Chicago Press, 2003.

Harriot, Thomas. A Briefe and True Report of the New Found Land of Virginia. New York: Dover, 1972.

Hawthorne, Nathaniel. The Blithedale Romance. New York, Ny: W.W. Norton and Company, 2011.

- The Letters, 1813-1843, Volume XV. Columbus, Oh: The Ohio State University Press, 1984.

Hayes, Shannon. Radical Homemakers: Reclaiming Domesticity from a Consumer Culture. Richmondville, NY: Left to Write Press, 2010. 
Heinzelman, Kurt. The Economics of the Imagination. Amherst: University of Massachusetts Press, 1980.

—. "The Last Georgic: Adam Smith's Wealth of Nations." In Texts in Culture: "The Wealth of Nations," eds. Stephen Copley and Katherine Sutherland. Manchester: Manchester University Press, 1995. 171-94.

—. "Roman Georgic in the Georgian Age: A Theory of Romantic Genre." Texas Studies in Literature and Language. 33.2 (1991): 182-214.

Heise, Thomas. Urban Underworlds: A Geography of Twentieth-Century American Literature and Culture. New Brunswick, Nj: Rutgers University Press, 2011.

Heise, Ursula. Sense of Place and Sense of Planet: The Environmental Imagination of the Global. Oxford: Oxford University Press, 2008.

Hellenbrand, Harold. "'A True Integrity Day by Day': Thoreau's Organic Economy in Walden." in Henry David Thoreau's Walden. ed. Harold Bloom. New York, Ny: Chelsea House, 1987. 69-78.

Heller, Eric. The Disinherited Mind. Cambridge: Bowes and Bowes, 1952.

Hemenway, Toby. Gaia's Garden: A Guide to Home-Scale Permaculture. Hartford, VT: Chelsea Green, 2009.

Hiltner, Ken. What Else is Pastoral? Renaissance Literature and the Environment. Ithaca, NY: Cornell University Press, 2011.

Holbo, Christine. "Imagination, Commerce, and the Politics of Associationism in Crèvecoeur's Letters from an American Farmer." Early American Literature. 32.1 (1997): 20-65.

Holmgren, David. Permaculture: Principles and Pathways Beyond Sustainability. Hepburn, Victoria: Holmgren Design Services, 2002.

Horrocks, Sam. "Faulkner's Ecologies and the Legacy of the Nashville Agrarians." in Ecocriticism and the Future of Southern Studies. ed. Zackary Vernon. Baton Rouge, La: LSU Press, 2019.

- "Planting-out after Blithedale: Transcendental Agrarianism and Ecocritical Economy." Resilience. 4.1 (2016): 44-59.

Imhoff, Daniel and Christina Badaracco. The Farm Bill: A Citizen's Guide. Washington DC: Island Press, 2019.

"industrialism, n." OED Online, Oxford University Press, December 2019, www.oed.com/view/Entry/94849. Accessed 6 January 2020. 
Jeavons, John. "Biointensive Sustainable Mini-Farming" Journal of Sustainable Agriculture. 19:2 (2001): 49-76.

Jefferson, Thomas. Notes on the State of Virginia. New York: Penguin, 1999.

- The Papers of Thomas Jefferson, vol. 1, 1760-1776, ed. Julian P. Boyd. Princeton: Princeton University Press, 1950.

Jennings, Justin. Globalizations and the Ancient World. Cambridge: Cambridge University Press, 2011.

Keegan, Bridget. British Laboring Class Nature Poetry, 1730-1837. New York: Palgrave Macmillan, 2008.

Kermode, Frank. English Pastoral Poetry: From the Beginnings to Marvell. London: George G. Harrap, 1952.

Kerridge, Eric. "The Agricultural Revolution Reconsidered." Agricultural History. 43.4 (1969): 463-476

Kidd, Colin. "Burns and Politics." in The Edinburgh Companion to Robert Burns. Ed. Gerard Carruthers. Edinburgh: Edinburgh University Press, 2009.

Kimbrell, Andrew ed. The Fatal Harvest Reader. Washington Dc: Island Press, 2002.

King, Franklin Hiram. Farmers of Forty Centuries. New York: Dover, 2004.

Klare, Michael. "A Tough Oil World." Huffington Post. 13 March, 2012.

Krech, Shepard. The Ecological Indian. New York: Norton, 1999.

Lamore, Eric. "Cultivating the Ancient Classical tradition in Early America: Vergil and J. Hector St. Jean de Crèvecoeur's Letters from an American Farmer." Atenea. 29.1 (2009): 113134.

Latour, Bruno. "An Attempt at a 'Compositionist Manifesto.'" New Literary History. 41.3 (2010): 471-490.

- On the Modern Cult of the Factish Gods. Durham, Nc: Duke University Press, 2010.

—. "Why Has Critique Run Out of Steam?" Critical Inquiry. 30.2 (2004): 225-248.

—. We Have Never Been Modern. Cambridge, Ma: Harvard University Press, 1993.

Lawrence, D.H. Studies in Classic American Literature. New York: Penguin Books, 1977. 
Landry, Donna. "Georgic Ecology." In Robert Bloomfield: Lyric, Class, and the Romantic Canon. Lewisburg: Bucknell University Press, 2006.

Leask, Nigel. Robert Burns and Pastoral. Oxford: Oxford University Press, 2010.

LeMenager, Stephanie. Living Oil: Petroleum Culture in the American Century. New York: Oxford University Press, 2014.

Lioi, Anthony. "Ursula Heise and her Work: Toward a Rhizomatic Review." Resilience: A Journal of the Environmental Humanities. 1.3 (2014)

Low, Anthony. The Georgic Revolution. Princeton NJ: Princeton University Press, 1985.

Lowder, Sarah, Jakob Skoet, Terri Raney. "The Number, Size, and Distribution of Farms, Smallholder Farms, and Family Farms Worldwide." World Development. 87 (2016): 16-29.

Lowell, Amy. "Edgar Lee Masters and Carl Sandburg." in Tendencies in Modern American Poetry. New York: Macmillan, 1917. 200-232.

Lukacs, Martin. "Neoliberalism has conned us into fighting climate change as individuals." The Guardian. July 17, 2017.

Lynch, Tom, Cheryll Glotfelty, and Karla Armbrester. The Bioregional Imagination: Literature, Ecology, and Place. Athens, Ga: University of Georgia Press, 2013.

Machor, James. "The Garden City in America: Crèvecoeur's Letters and the Urban-Pastoral Context." American Studies. 23.1 (1982): 69-83.

Marsh, John. "A Lost Art of Work: The Arts and Crafts Movement in Carl Sandburg's Chicago Poems." American Literature. 79.3 (2007): 527-551.

Martinez-Alier, J. Ecological Economics: Energy, Environment and Society. Oxford: Basil Blackwell, 1987

_- "Some issues in agrarian and ecological economics, in memory of Georgescu-Roegen." Ecological Economics. 22.3 (1997): 225-238.

Major, Willam. Grounded Vision: Agrarianism and the Academy. Tuscaloosa, AL: University of Alabama Press, 2008.

Marx, Karl. Capital, Volume I. New York: Vintage, 1976.

Marx, Leo. The Machine in the Garden. Oxford: Oxford University Press, 1964. 
Mayer, Charles. "The People, Yes: Sandburg's Dreambook for Today." Vision of this Land. Ed. John Hallwas. Macomb, IL: Western Illinois University Press, 1976. 82-91.

Maynard, Luke. "Hoddin' Grey an' A' That: Robert Burns's Head, Class Hybridity, and the Value of the Ploughman's Mantle." in The Working Class Intellectual in Eighteenth- and Nineteenth-Century Britain. Ed. Aruna Krishnamurthy. New York: Routledge, 2009.

McGinty, Walter. Robert Burns and the Philosophers. New York: Routledge, 2018.

McKelvey, Seth. "'But one kind' of Life: Thoreau's Subjective Theory of Value in Walden." Nineteenth-Century Literature. 70.4 (2016): 448-472.

McKeon, Michael. "The Pastoral Revolution." In Refiguring Revolutions. Berkeley: University of California Press, 1998.

McRae, Andrew. God speed the plough: The Representation of Agrarian England 1500-1660. Cambridge: University Press, 1996.

Mollison, Bill. Permaculture: A Designers' Manual. Berkeley, Ca: Ten Speed Press, 1997.

Montmarquet, James. "American Agrarianism: The Living Tradition." in The Agrarian Roots of American Pragmatism. Eds. Paul Thompson and Thomas Hilde. Nashville, Tn: Vanderbilt University Press, 2000.

Moore, Dennis, "Introduction: Moving Beyond the Farmer of Feelings." in Letters from an American Farmer and Other Sketches. Cambridge: Belknap Press, 2013.

Morris, William. News from Nowhere and Other Writings. London: Penguin, 2004.

Morton, Timothy. Hyperobjects: Philosophy and Ecology after the End of the World. Minneapolis, Mn: University of Minnesota Press, 2013.

Miller, Perry. The Transcendentalists: An Anthology. Cambridge, Ma: Harvard University Press, 1950.

Mumford, Lewis. The Culture of Cities. New York: Harvest/HBJ, 1970.

Murphy, Denis. People, Plants and Genes: The Story of Crops and Humanity. Oxford: Oxford University Press, 2007.

Myers, James. "Crèvecoeur : Concealing and Revealing the Secret Self." Early American Literature. 49.2 (2014): 357-401.

Neely, Michelle. "Embodied Politics: Antebellum Vegetarianism and the Dietary Economy of Walden." American Literature. 85.1 (2013): 33-60. 
Newman, Lance. Our Common Dwelling: Henry Thoreau, Transcendentalism, and the Class Politics of Nature. New York, Ny: Palgrave Macmillan, 2005.

Nixon, Rob. Slow Violence and the Environmentalism of the Poor. Cambridge: Harvard University Press, 2011.

Northrup, Benjamin and Benhamin Lipscomb. "Country and City: The Common Vision of Agrarians and New Urbanists." in The Essential Agrarian Reader. ed. Norman Wirzba. Washington Dc: Shoemaker and Hoard, 2004.

Obach, Brian. Organic Struggle: The Movement for Sustainable Agriculture in the United States. Cambridge, Ma: Massachusetts Institute of Technology Press, 2015.

Orr, David. "The Urban-Agrarian Mind." In The New Agrarianism: Land, Culture, and the Community of Life. Ed. Eric Freyfogle. Washington: Island Press, 2001. 93-107.

Osbourne, Jeff. "American Antipathy and the Cruelties of Citizenship in Crèvecoeur's Letters from an American Farmer." Early American Literature. 42.3 (2007): 529-553.

Overton, Mark. Agricultural Revolution in England: The Transformation of the Agrarian Economy 1500-1850. Cambridge: Cambridge University Press, 1996.

Parini, Jay. "The Greening of the Humanities." The New York Times Magazine. October 291995.

Penniman, Leah. Farming While Black. White River Junction, Vt: Chelsea Green, 2018.

Philbrick, Thomas. St. John de Crèvecoeur. New York: Twayne, 1970.

Pine Hill Farm. Pine Hill Farm, 2010. www.pinehillfarmvegetables.com.

Plumwood, Val. "Shadow Places and the Politics of Dwelling." Australian Humanities Review. 44 (2008): 139-150.

Pope, Alexander. The Complete Poetical Works, ed. by Henry W. Boynton. Boston and New York: Houghton, Mifflin \& Co., 1903; Bartleby.com, 2011.

Ransom, John Crowe. "Introduction" in I'll Take My Stand: The South and the Agrarian Tradition, ed. Twelve Southerners. Baton Rouge: LSU Press, 1977.

Rapping, Elayne. "Theory and Experience in Crèvecoeur's America." American Quarterly. 19.4 (1967): 707-718.

Reed, Brian. "Carl Sandburg's The People, Yes, Thirties Modernism, and the Problem of Bad Political Poetry." Texas Studies in Language and Literature 46.2 (2004): 181-212. 
Resnick, Stephen and Richard Wolfe. Class Theory and History: Capitalism and Communism in the USSR. New York: Routledge, 2002.

Regis, Pamela. Describing Early America. Philadelphia: University of Pennsylvania Press, 1999.

Robinson, David. "Community and Utopia in Crèvecoeur's Sketches." American Literature. 62.1 (1990): 17-31.

_. "Unchronicled Nations": Agrarian Purpose and Thoreau's Ecological Knowing. Nineteenth-Century Literature, 48.3 (1993): 326-340.

Rosenmeyer, Thomas. The Green Cabinet: Theocritus and the European Pastoral Lyric. Berkeley: University of California Press, 1973.

Rotella, Carlo. October Cities: The Redevelopment of Urban Literature. Berkeley, Ca: University of California Press, 1998.

Ruskin, "The Stones of Venice." In The Norton Anthology of English Literature. Ed. M.H. Abrams et al. New York, Ny: Norton, 1993.

Sandburg, Carl. The Complete Poems of Carl Sandburg. New York, Ny: Harcourt Brace Jovanovich, 1970.

Sarver, Stephanie. Uneven Land: Nature and Agriculture in American Writing. Lincoln Nb: University of Nebraska Press, 1999.

Sattelmeyer, Robert. Thoreau's Reading. Princeton Nj: Princeton University Press, 1991.

Saunders, Judith. "Economic Metaphor Redefined: The Transcendental Capitalist at Walden." in Henry David Thoreau's Walden. ed. Harold Bloom. New York, Ny: Chelsea House, 1987. 59-67.

Sayre, Robert. Thoreau and the American Indians. Princeton Nj: Princeton University Press, 1977.

Schliephake, Christopher. Urban Ecologies. Lanham, Md: Lexington Books, 2015.

Schumacher, E.F. Small is Beautiful. New York: HarperCollins, 2010.

Scott, James C. Against the Grain: A Deep History of the Earliest States.. New Haven: Yale University Press, 2017.

- Weapons of the Weak. New Haven: Yale University Press, 1987.

Shi, David. The Simple Life: Plain Living and High Thinking in American Culture.. Athens, Ga: University of Georgia Press, 1997. 
Smith, Adam. The Wealth of Nations. New York: Modern Library, 1937.

Smith, Henry Nash. Virgin Land: The American West as Symbol and Myth. Cambridge: Harvard University Press, 1950.

Snell, Bruno. The Discovery of the Mind: The Greek Origins of European Thought, trans T.G. Rosenmeyer. Cambridge, Ma: Harvard University Press, 1953.

Sweet, Timothy. American Georgics: Economy and Environment in Early American Literature. Philadelphia: University of Pennsylvania Press, 2002.

—. "Environment." in New Histories of American Puritan Literature. Eds. Kristina Bross and Abram van Engen. Cambridge: Cambridge University Press, forthcoming.

_. "Pastoralism and the Marketplace: Eighteenth-Century Ideologies of Farming." Early American Literature. 29.1 (1994): 59-80

Tillman, James. "The Transcendental Georgic in Walden." in Critical Essays on Henry David Thoreau's Walden. ed. Joel Myerson. Boston: G. K. Hall, 1988.

Tholoniat, Yann. "Robert Burns and Jean-Jacques Rousseau: Sensitive Hearts, Big Mouths." In Romanticism and the Philosophical Tradition. Ed. Thomas Constantinesco and Sophie Laniel-Musitelli. Nancy: Presses universitaires de Nancy, 2015.

Thompson, Paul. The Agrarian Vision: Sustainability and Environmental Ethics. Lexington, Ky: University Press of Kentucky, 2010.

Thoreau, Henry David. The Higher Law: Thoreau on Civil Disobedience and Reform. Ed. Wendell Glick. Princeton, Nj: Princeton University Press, 2004.

—. Walden. Princeton: Princeton University Press, 2004.

—. "Walking. "in Henry David Thoreau: Collected Essays and Poems. Ed. Elizabeth Witherell. New York, Ny: Library of America, 2001.

- A Week on the Concord and Merrimack Rivers. Ed. Robert Sayre. New York, Ny: Library of America, 1985.

—. Wild Fruits. Ed. Bradley Dean. New York, Ny: Norton, 2000.

—. The Writings of Henry David Thoreau: Journal, Vol. I. Boston, Ma: Houghton Mifflin, 1906.

Veblen, Thorstein. The Theory of the Leisure-Class. New York: New American Library, 1953. 
Villarreal, Evert. Recovering Carl Sandburg: Politics, Prose, and Poetry after 1920. 2006. Texas A\&M University, PhD dissertation.

Virgil. Eclogues. Trans. Len Krisak. Philadelphia, Pa: University of Pennslyvania Press, 2012.

—. Georgics. Trans. John Dryden. New York: Heritage Press, 1953.

Wald, Sarah. The Nature of California: Race, Citizenship, and Farming since the Dust Bowl. Seattle: University of Washington Press, 2016.

Wallace, Anne. "Farming on Foot: Tracking Georgic in Clare and Wordsworth." Texas Studies in Literature and Language. 34.4 (1992): 509-540

Walls, Laura Dassow. Henry David Thoreau: A Life. Chicago, Il: University of Chicago Press, 2017.

Washington, George. "To Richard Henderson, 19 June 1788." in The Washington Papers, ed. Saul Padover. New York: Harper, 1955. 358.

White, Morton and Lucia White. The Intellectual Versus the City, From Thomas Jefferson to Frank Lloyd Wright. Cambridge Ma: Harvard University Press, 1962.

White, Richard. "Are You an Environmentalist or Do You Work For a Living?: Work and Nature." Uncommon Ground, ed. William Cronon. New York: Norton, 1995.

White, Simon. Romanticism and Rural Community. Hampshire: Palgrave Macmillan, 2013.

Williams, Raymond. The Country and the City. New York: Oxford University Press, 1975.

—. Marxism and Literature. Oxford: Oxford University Press, 1978.

Wirzba, Norman, ed. The Essential Agrarian Reader. Washington Dc: Shoemaker and Hoard, 2004.

Wolff, Richard. Democracy at Work: A Cure for Capitalism. Chicago: Haymarket Books, 2012.

Yanella, Philip. The Other Carl Sandburg. Jackson: Ms: University of Mississippi Press, 1996.

Ziser, Michael. Environmental Practice and Early American Literature. Cambridge: Cambridge University Press, 2013.

—. "Walden and the Georgic Mode." in More Day to Dawn: Thoreau's Walden For the Twenty-first Century. Eds. Sandra Harbert Petrulionis and Laura Dassow Walls. Amherst: University of Massachusetts Press, 2007 